\title{
Modelling Mitochondrial Disease in Human Pluripotent Stem Cells: What Have We Learned?
}

\author{
Cameron L. McKnight 1,2, ${ }^{+}$, Yau Chung Low ${ }^{1,2,+}$, David A. Elliott ${ }^{1,2} \mathbb{D}$, David R. Thorburn ${ }^{1,2,3}(\mathbb{D}$ \\ and Ann E. Frazier 1,2,*(D)
}

1 Murdoch Children's Research Institute, Royal Children's Hospital, Parkville, VIC 3052, Australia; cameron.mcknight@mcri.edu.au (C.L.M.); yau.low@mcri.edu.au (Y.C.L.); david.elliott@mcri.edu.au (D.A.E.); david.thorburn@mcri.edu.au (D.R.T.)

2 Department of Paediatrics, University of Melbourne, Parkville, VIC 3052, Australia

3 Victorian Clinical Genetics Services, Royal Children's Hospital, Parkville, VIC 3052, Australia

* Correspondence: ann.frazier@mcri.edu.au

+ These authors contributed equally to this work.

Citation: McKnight, C.L.; Low, Y.C.; Elliott, D.A.; Thorburn, D.R.; Frazier, A.E. Modelling Mitochondrial Disease in Human Pluripotent Stem Cells: What Have We Learned? Int. J. Mol. Sci. 2021, 22, 7730. https:// doi.org/10.3390/ijms22147730

Academic Editors: María

Eugenia Soriano and Carlo Viscomi

Received: 30 June 2021

Accepted: 16 July 2021

Published: 20 July 2021

Publisher's Note: MDPI stays neutral with regard to jurisdictional claims in published maps and institutional affiliations.

Copyright: (c) 2021 by the authors. Licensee MDPI, Basel, Switzerland. This article is an open access article distributed under the terms and conditions of the Creative Commons Attribution (CC BY) license (https:/ / creativecommons.org/licenses/by/ $4.0 /)$.

\begin{abstract}
Mitochondrial diseases disrupt cellular energy production and are among the most complex group of inherited genetic disorders. Affecting approximately 1 in 5000 live births, they are both clinically and genetically heterogeneous, and can be highly tissue specific, but most often affect cell types with high energy demands in the brain, heart, and kidneys. There are currently no clinically validated treatment options available, despite several agents showing therapeutic promise. However, modelling these disorders is challenging as many non-human models of mitochondrial disease do not completely recapitulate human phenotypes for known disease genes. Additionally, access to diseaserelevant cell or tissue types from patients is often limited. To overcome these difficulties, many groups have turned to human pluripotent stem cells (hPSCs) to model mitochondrial disease for both nuclear-DNA (nDNA) and mitochondrial-DNA (mtDNA) contexts. Leveraging the capacity of hPSCs to differentiate into clinically relevant cell types, these models permit both detailed investigation of cellular pathomechanisms and validation of promising treatment options. Here we catalogue hPSC models of mitochondrial disease that have been generated to date, summarise approaches and key outcomes of phenotypic profiling using these models, and discuss key criteria to guide future investigations using hPSC models of mitochondrial disease.
\end{abstract}

Keywords: stem cell; hPSC; iPSC; hESC; CRISPR-Cas9; mtDNA; disease modelling; mitochondrial disease

\section{Introduction}

So much more than just "the powerhouse of the cell", mitochondria also handle critically important biochemical processes including cell signalling, iron-sulfur (Fe/S) cluster biogenesis, apoptosis, and calcium homeostasis [1,2]. Nonetheless, mitochondrial diseases are classified as disorders of energy generation that either directly or indirectly affect ATP production via the oxidative phosphorylation (OXPHOS) system. One of the most complex groups of inherited genetic conditions, they can result from mutations in either nuclear (nDNA) or mitochondrial DNA (mtDNA). Additionally, patient phenotypes can be highly heterogeneous and tissue specific, making them difficult to diagnose and study [3].

Despite there being over 1100 known mitochondrial proteins, only 37 genes are encoded on the small $(16 \mathrm{~kb})$ circular double-stranded mtDNA (2 ribosomal RNAs (rRNAs), 22 transfer RNAs (tRNAs), and 13 OXPHOS subunits) [4,5]. Unlike the nuclear genome, mtDNA is entirely maternally inherited [6] and each cell contains hundreds to thousands of copies [7]. Copy number varies between cell types, as can the proportion of mutated copies [8-10]. The ratio of mutant to wild type mtDNA (i.e., heteroplasmy) that leads to 
disease can be both cell type and mutation specific [11,12]. Heteroplasmy can be affected by a number of factors, including a genetic bottle neck during embryogenesis [13] and genetic drift over generations [14]. The OXPHOS system itself is made up of five multi-subunit complexes (Complexes I-V; CI-CV) inserted into the inner mitochondrial membrane [15]. With only 13 of the 90 OXPHOS subunits being mtDNA encoded [16], mitochondria are dependent on import of more than 250 additional nuclear encoded proteins and assembly factors required for OXPHOS function [17,18].

With over 330 different mitochondrial disease genes identified between the two genomes, it has become apparent that it will be a monumental task to model all of the distinct genes and mutations $[19,20]$. Furthermore, available patient cell lines such as fibroblasts do not always display disease phenotypes [21], and accessing disease relevant tissues from patients can be difficult or limited. These efforts have been further compounded by the inability of some non-human model systems to recapitulate the human phenotypes for certain key disease genes [22]. In the case of SURF1-related Leigh syndrome for example, SURF1 knockout mice and pigs did not show significant neurological phenotypes despite their characteristic decreased complex IV expression, with the mice also living longer and showing resistance to cytotoxic stress [23-25]. A range of other mitochondrial diseasespecific mouse models have been developed over the years, but many of them still have caveats that make it challenging to conduct treatment studies [26].

Despite several promising treatment options, there are no clinically validated treatments for mitochondrial diseases $[3,27]$, with most patients instead receiving tailored symptomatic treatments, even following a genetic diagnosis [28,29]. With a relative lack of non-human models amenable to high-throughput screening approaches, human pluripotent stem cell (hPSC) models of mitochondrial disease offer a promising alternative as a drug discovery platform [3].

\section{Pluripotent Stem Cells in Mitochondrial Disease Modelling}

Pluripotent stem cells are defined by the capacity to give rise to cells from all three germ layers and indefinitely self-renew (Figure 1) [30]. This unique potential is advantageous for human mitochondrial disease modelling.

Since the first human embryonic stem cells (hESCs) were isolated from the inner cell mass of an excess IVF blastocyst in 1998, it was clear that these cells had great potential for disease modelling and cell therapy [31]. However, over the past 15 years, much research has gone into optimising induced pluripotent stem cell (iPSC) technologies to ensure human somatic cells reprogrammed to a stem cell fate are equivalent to hESC in every relevant metric $[32,33]$. Now considered largely equivalent, it is acceptable to choose either embryonic or induced human pluripotent stem cells (hPSCs) for disease modelling based on experimental requirements. Nonetheless, caveats remain for iPSCs, including variations in methylation state, copy number, and transcription that can be influenced by reprogramming methods and somatic cell origin [34].

Numerous protocols have been developed to differentiate hPSCs to specific cell fates either using growth factors and small molecules to mimic signals from embryogenesis for a given cell lineage, or via direct gene regulation approaches [35,36]. This can be done in 2D to look at more homogeneous cell populations, or in 3D as an organoid system to better approximate the tissue environment for a given cell type. While organoids offer a more complex cell network with multiple cell types, they can be difficult to form consistently and can require significant optimisation for different cell lines [37,38]. 


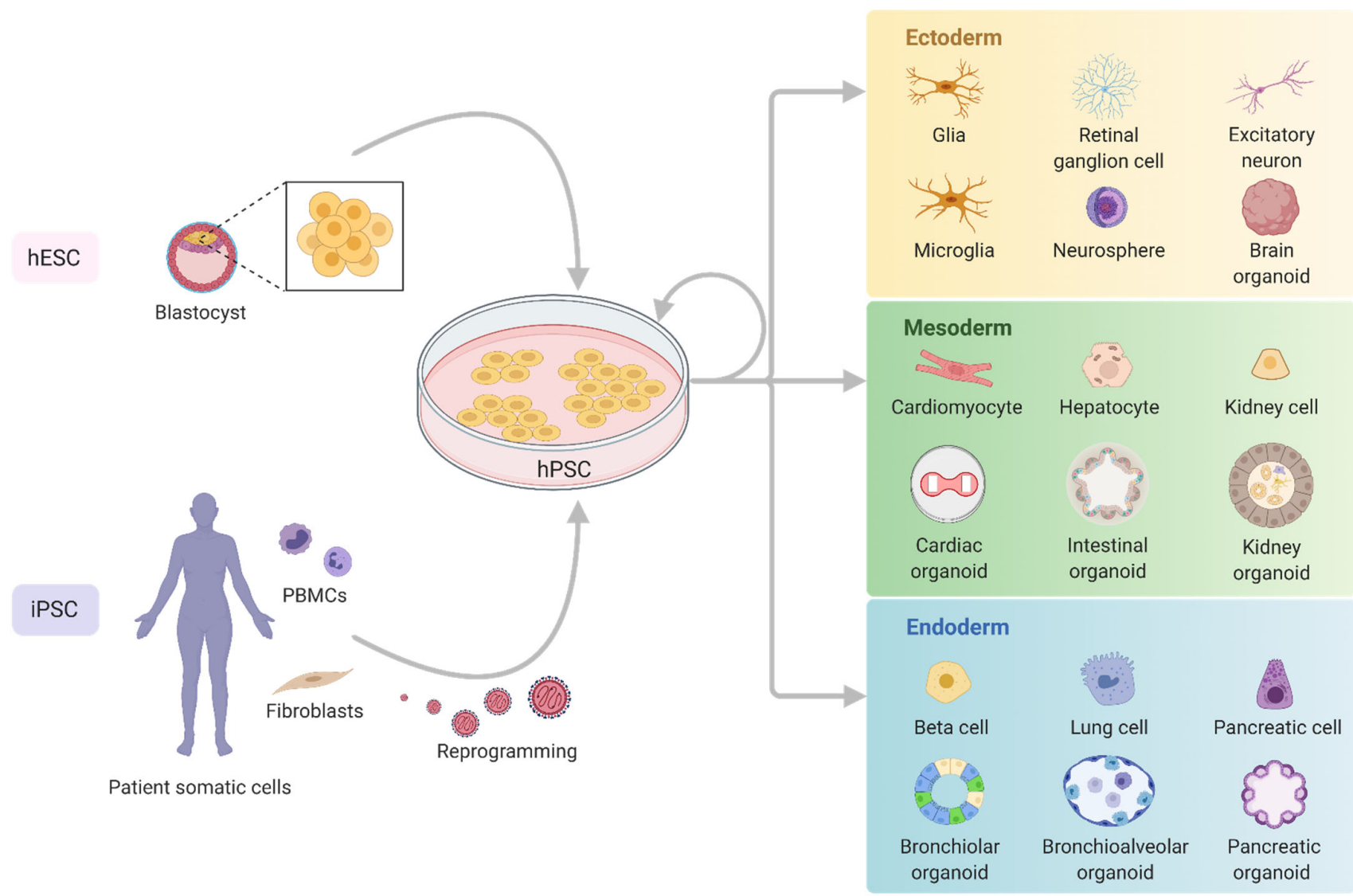

Figure 1. Generation and utility of human stem cell models. Human pluripotent stem cells (hPSCs) can be generated either from the inner cell mass of a blastocyst, known as human embryonic stem cells (hESCs), or by reprogramming a host's somatic cells, most commonly fibroblasts or peripheral blood mononuclear cells (PBMCs), to make induced pluripotent stem cells (iPSCs). Both forms of hPSCs are capable of indefinite self-renewal and can differentiate to the three primary germ layers. This capacity to differentiate can be directed experimentally to form terminally differentiated cell types or more complex organoid models, making hPSCs suitable for modelling the multitude of systems affected by mitochondrial diseases.

In a mitochondrial disease context, hPSCs have many attractive characteristics. Principally, hPSCs are highly glycolytic and are not heavily reliant on OXPHOS for energy generation [39]. This implies that mitochondrial mutant cell lines should be stable and grow normally in a stem cell state. However, there could be complications when differentiating some more severe mitochondrial disease models since differentiation often requires rapid mitochondrial biogenesis and increased reliance on OXPHOS as the cells mature [40-43]. These issues would likely be mutation specific and may require modification of the differentiation conditions to better support the mutant line [44-48]. However, not all mutations will have differentiation issues and the resulting cell types can overcome the tissue specific challenges of studying these complex disorders.

This review will highlight hPSC models of mitochondrial disease that have been generated to date for the purposes of disease modelling and has not included any lines generated for other purposes (e.g., studying cell therapies [49,50], diabetes [51], aging [52]). We have also opted not to include genes linked to other metabolic pathways (e.g., mitochondrial fatty acid oxidation) or mitochondrial-linked disorders with distinct phenotypes such as Parkinson's disease [53-57]. We will summarise approaches used to phenotype and investigate these models as well as key outcomes. We will also suggest common validation criteria that could better standardise future studies of hPSC models of mitochondrial disease and any downstream investigations. 


\section{Generation of Human Pluripotent Stem Cell Mitochondrial Disease Models \\ 3.1. Technologies and Considerations for Generating hPSC Disease Models}

Generation of a mitochondrial disease specific hPSC model is not dissimilar to any other hPSC line when it comes to nDNA mutations. However, modelling mtDNA mutations involves some unique challenges and techniques that must be considered due to potential issues with mtDNA heteroplasmy. For an overview of the pathways available for generation of hPSC models and considerations for mitochondrial disease, see Figure 2(A1,A2), and sections below.
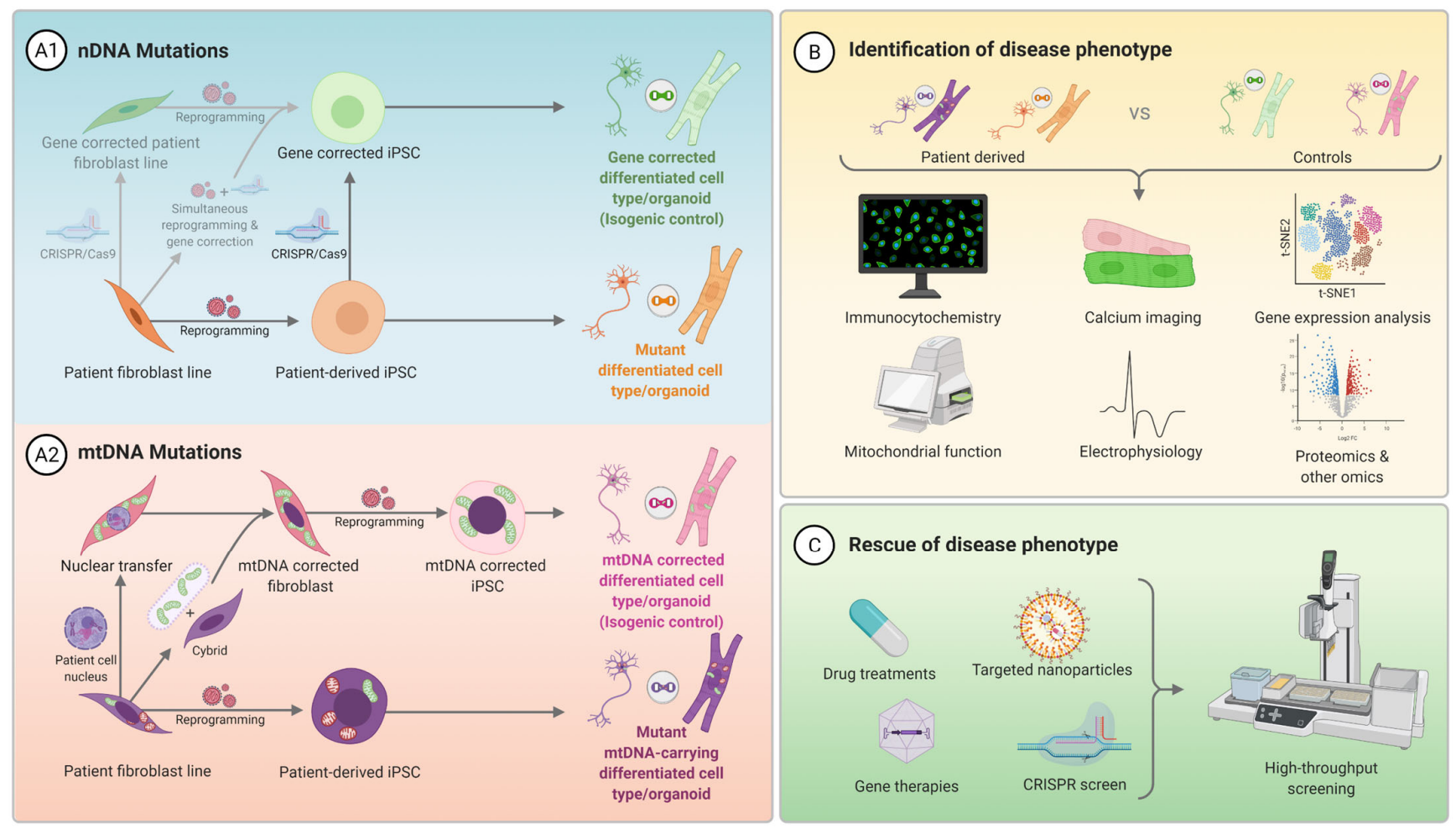

Figure 2. Pathways to modelling mitochondrial diseases using iPSCs. (A1) Using genetic editing approaches (e.g., CRISPRCas9), gene corrected iPSCs can be generated for individual mitochondrial disease patient fibroblast lines (or PBMCs) with nDNA mutations. For the studies included in this review, the generation of isogenic controls by gene editing has all been done post-reprogramming, but it is also possible to do simultaneously, or prior to reprogramming. Gene editing has also been done inversely in hPSCs to generate mutation lines with the parental line as the isogenic control. (A2) Generation of isogenic controls for mtDNA mutation lines is commonly achieved prior to reprogramming, either by patient cell nuclear transfer to an enucleated WT mtDNA host cell line or by cybrid formation. (B) Differentiation of controls alongside hPSC mutant lines makes it possible to identify phenotypic differences in both nDNA and mtDNA models using different functional analyses and/or omics technologies. (C) By adapting functional analysis techniques for high-throughput screens, it is possible to identify or validate candidate treatment options such as compounds, targeted nanoparticle approaches, gene therapies, or CRISPR-Cas9 screens to pinpoint target pathways.

An important consideration for mitochondrial disease or other hPSC studies is the choice of controls to be used for comparison. Many of the publications reported here have directly compared patient iPSC lines to a pool of non-isogenic controls, i.e., with a different genetic background (and not always age and/or sex matched). Although a pool of at least three age- and sex-matched non-isogenic controls may be a reasonable approach, due to the variabilities in reprogramming and differentiation processes it has been shown that only isogenic controls can provide sufficiently robust data to detect subtle phenotypic differences $[58,59]$. The need for just a single control may also be important for scalability of downstream drug screens, making this an important consideration during cell line generation [59]. Fortunately, generation of isogenic controls has become increasingly 
simple as gene editing becomes more commonplace. Using CRISPR-Cas9 to correct nDNA patient mutations can be done before [60], after [61], or even during reprogramming [62] (Figure 2(A1)). For mtDNA disorders, this can be accomplished with traditional techniques like somatic cell nuclear transfer or cybrids [63-65]. Both approaches result in the patient nDNA in a wild type mtDNA background but must be done prior to reprogramming (Figure 2(A2)). Additionally, in some cases, the reprogramming process can result in some clones with wild type homoplasmy, which can be used as isogenic controls for mtDNA-based stem cell studies $[21,45,66]$.

\subsubsection{Reprogramming of Somatic Cells into iPSCs}

Reprogramming to an iPSC fate involves reverting a terminally differentiated cell type, typically fibroblasts or peripheral blood mononuclear cells (PBMCs), to an uncommitted pluripotent stem cell fate by transient expression of Oct4 (Pou5f1), Sox2, Klf4, and cMyc [67]. This can be accomplished using a range of technologies and Figure 3 outlines the technologies used to generate the mitochondrial stem cell models published to date [68].

Since the first extensive characterisations of iPSC mitochondrial disease models in $2013[21,45,69]$, the choice of reprogramming method has largely been influenced by the predominant technology at the time of generation [68]. Integrative viral vectors like retrovirus and lentivirus were common in early iPSC studies due to their high efficiency and ease of use. However, they were later revealed to be subpar activators of endogenous pluripotency genes and carried a high risk of detrimental gene integration events [70]. This led the field to move towards non-integrative viral approaches like Sendai virus. Although significantly lower in efficiency [71], Sendai virus is still a popular reprogramming method for its relative simplicity and cost effectiveness. To date, Sendai virus has been used to reprogram most mitochondrial disease iPSC models (Figure 3). More recent advances in reprogramming technology have come in the form of non-integrative non-viral systems, such as episomal vectors and modified RNA (modRNA) [72,73]. Each advance in reprogramming technology has offered increased safety and efficacy for therapeutic applications of iPSCs and these trickle down as new standards for research use as efficiency increases and costs decrease over time. Although non-integrative non-viral technologies were only used to generate a small subset of the mitochondrial disease iPSC models included here (Figure 3), episomal vectors are already beginning to phase out Sendai virus in the therapeutic setting and will likely account for most mitochondrial disease iPSC lines generated in the future [74].

In the context of mitochondrial disease, genetic background can play a major role, making iPSCs a particularly valuable modelling tool. For patients with complex nDNA mutations or variants of uncertain significance (VUS), where there may be secondary mutations contributing to the phenotype, this could be the only approach to effectively capture the genetic complexity of these conditions.

\subsubsection{Gene Editing}

For both iPSCs or hESCs, CRISPR-Cas9 is an invaluable tool in the generation of either patient corrected isogenic controls or recreating a patient mutation in a wild type genetic background [76] (Figure 2(A1,A2)), and has been successfully used to generate several mitochondrial disease hPSC models (Figure 3 and Table A1). CRISPR-Cas9 technology has been adapted from the bacterial viral defence system to work efficiently as a precise genetic editing tool in human cells by generating targeted double- or single-stranded breaks within a $\sim 20$ bp guide sequence that corresponds to a single location in the nuclear genome [77].

Manipulation of the mitochondrial genome is less straightforward. Due to the apparent lack of a mitochondrial RNA import machinery, CRISPR-Cas9 does not appear to be a viable option for editing mtDNA [78]. However, other options include mitochondrialtargeted transcription activator-like effector nucleases (mitoTALENs) [79], which target specific point mutations to decrease heteroplasmy levels or even generate isogenic controls with homoplasmic WT mtDNA $[79,80]$. While this technique provides a powerful tool 
to modify heteroplasmy levels in hPSCs, it has only been applied in two of the studies identified in this review [80,81].

Other approaches, such as mitochondrial-targeted zinc-finger nucleases (mtZFN) and restriction endonucleases (mitoRE), could also produce a similar effect [82], but their use has not yet been reported in hPSCs. Similarly, the recently described RNA-free DddA-derived cytosine base editors (DdCBEs) could provide more precise control over heteroplasmy without impacting mtDNA copy number [83], but have yet to be validated in hPSCs.

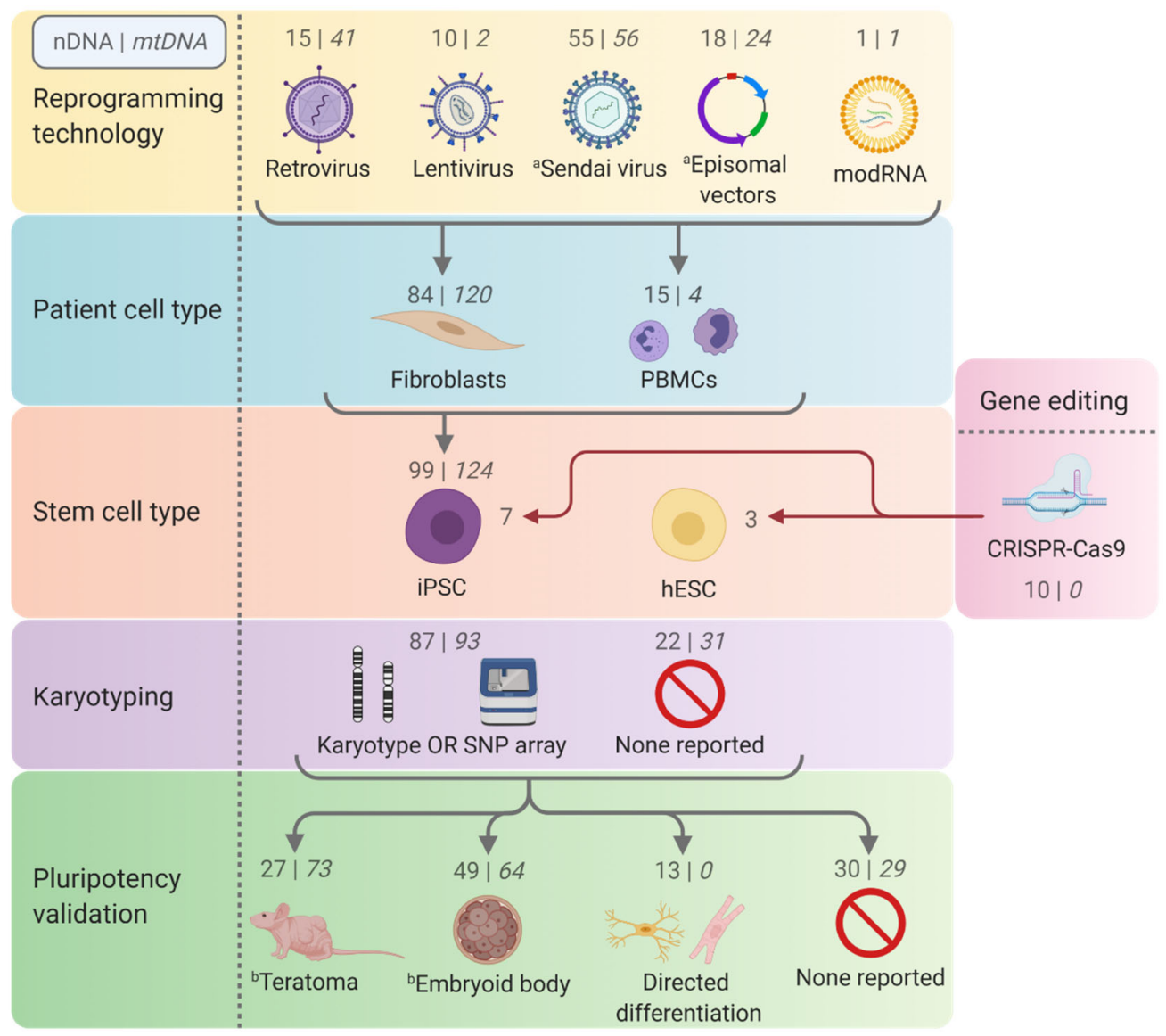

Figure 3. Generation and validation of mitochondrial disease iPSC lines. A graphical illustration of the various pathways used to generate and validate the mitochondrial disease hPSC lines described in Tables A1 and A2, indicating the number of nDNA and mtDNA clones generated from each somatic cell type by the technologies used in the process. The counts include all validated and reported clones generated for each nDNA and mtDNA cell line (with $>30 \%$ mutant heteroplasmy for mtDNA lines) to highlight the discrepancy in the number of clones often generated and screened for mtDNA lines versus nDNA lines due to variable heteroplasmy following reprogramming. For some nDNA lines, CRISPR-Cas9 gene editing was used to generate mitochondrial disease gene mutations in wild type hPSC backgrounds. Two key steps in the validation of iPSC lines are karyotyping or SNP (single nucleotide polymorphism) array analysis and pluripotency validation. Karyotype analysis minimises the risk that any unanticipated chromosomal rearrangements may have occurred during reprogramming. Pluripotency validation must demonstrate the ability to generate the three germ layers, in addition to the expression of pluripotency markers (e.g., SSEA4, TRA-1-81, TRA-1-61) [75]. a Fibroblasts were used as the patient somatic cell type for all lines except for 10 nDNA and 4 mtDNA mutation clones using Sendai virus and 5 nDNA mutation clones reprogrammed using episomal vectors. ${ }^{b} 10$ nDNA and 42 mtDNA lines were double counted as they were validated by both teratoma and embryoid body assays. 


\subsection{Quality Control and Characterisation of Pluripotent Stem Cell Disease Models}

The process of generating a hPSC line is lengthy and can be stressful for the cell, potentially allowing for the accumulation of deleterious genomic and phenotypic changes along the way [84]. Therefore, it is important that quality checks are performed on each cell line to ensure any phenotypes are not merely a consequence of the generation process. Several standards have been set out for therapeutic use of stem cells and the research field has adopted a number of these validation steps to ensure the quality of research cell lines $[75,85]$. We would therefore recommend that all mitochondrial disease hPSC models are screened for mycoplasma, normal karyotype, normal cell morphology, as well as pluripotency by FACS and trilineage differentiation to an EB, teratoma, or via directed differentiation to the three germ layers [85]. Although most of the cell lines included in this review did achieve this level of validation, there were a significant proportion that did not disclose the karyotype results of their lines and/or validation of their pluripotency (Figure 3; Tables A1 and A2). These validation steps should be standard for all iPSC lines, not just those modelling mitochondrial diseases.

In addition to the above standard screening procedures, it is recommended that iPSCs should also undergo DNA-fingerprinting analysis. This can be done by SNP analysis of parental somatic cell DNA for cross-referencing. This was not disclosed by many of the included studies (Tables A1 and A2) but is now considered an important step to ensure the validity of all comparisons. It is possible for cell lines to get mixed up and/or contaminated during reprogramming, or for large numbers of SNPs to change during the reprogramming process, so high-resolution DNA-fingerprinting is critical to ensure valid isogenic controls and disease models [86].

mtDNA heteroplasmy in iPSCs has proven to be a challenging area that could significantly contribute to the variability found between iPSC lines and to differentiation issues (Figure 4) $[87,88]$. The reprogramming process itself can evidently be subject to a genetic bottleneck effect and yield hPSC clones with different levels of heteroplasmy from the same patient somatic cell line [21,66]. In general, heteroplasmy appears to bias toward a decreased mutant load following either reprogramming or extended cell culture [45,87,89], potentially indicating that high mutant loads are not well tolerated $[69,90]$. In contrast, directed differentiations have been reported to maintain the heteroplasmy level of the starting hPSCs [21,91,92]. While undirected differentiations in teratomas have been reported to increase the overall mutant load [93], for other mtDNA mutations, heteroplasmy levels in teratomas were unchanged from the starting iPSC population [21]. Therefore, any biases may depend on the specific mtDNA mutation and be controlled by selection, with other mechanisms such as genetic bottleneck and genetic drift only playing a minor role following reprogramming [91]. Hence, it is critical that heteroplasmy is carefully monitored and cell lines are not kept in extended culture without consistent validation of heteroplasmy. Additionally, threshold levels for the mutant load required to manifest a disease phenotype can vary considerably for each individual mtDNA mutation and need to be considered [3]. 


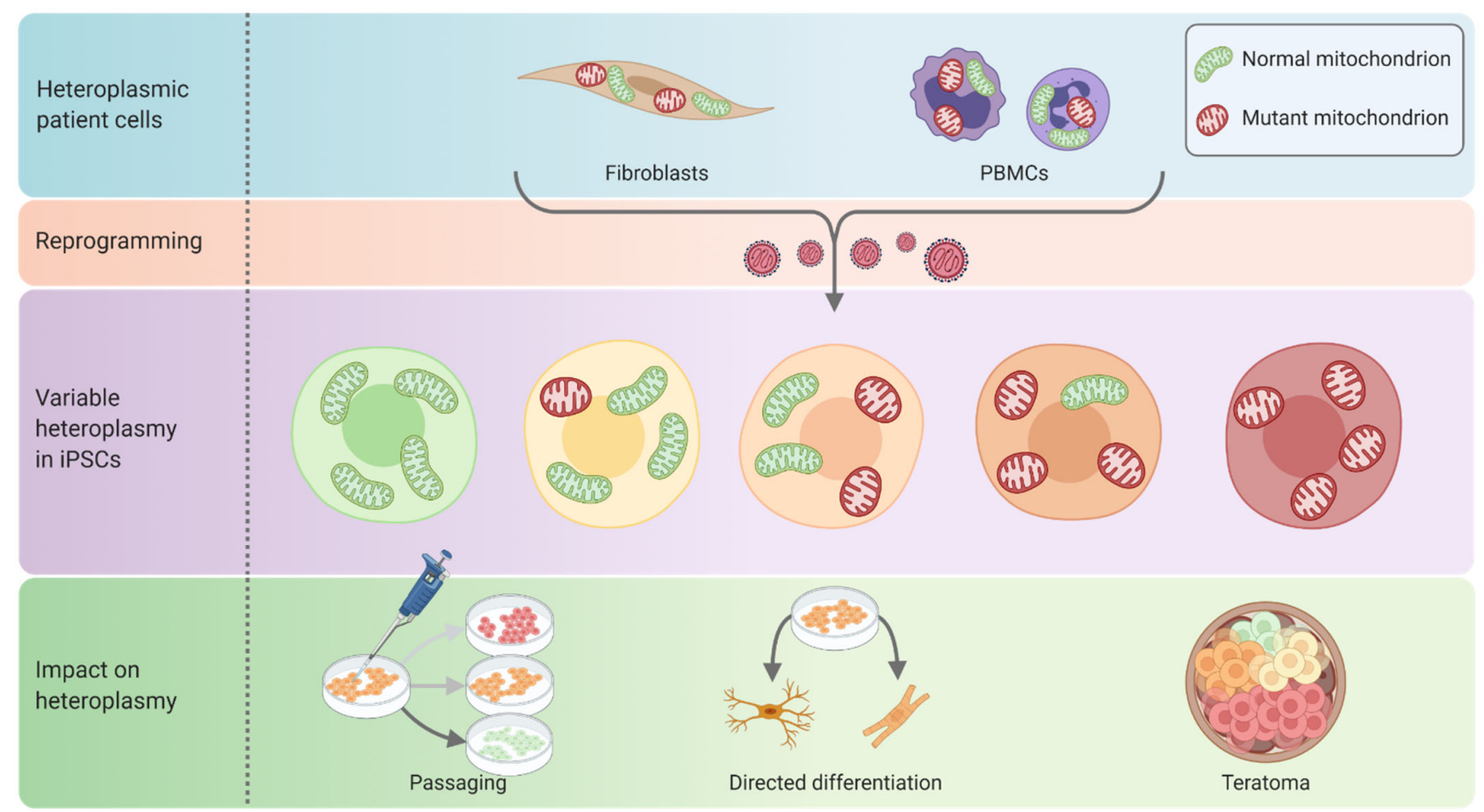

Figure 4. Maintenance of mtDNA heteroplasmy in iPSCs. Generation of iPSC lines from patient cells with mtDNA mutations can result in a shift in heteroplasmy from the somatic cell levels in either direction [21,66], although biased toward loss of mutant load [45,89]. Similarly, heteroplasmy can shift in either direction as heteroplasmic iPSC lines (orange cells) are passaged, with a general bias towards a decreased mutant load over time (green cells, lower mutant load; red cells, higher mutant load) $[45,69,87,90]$. During directed differentiation, heteroplasmy is typically unchanged from the level observed in the undifferentiated iPSCs [21,91,92]. However, during teratoma assays, different cell lineages can end up manifesting cell-type specific OXPHOS defects that may depend on the specific mtDNA mutation [21,93]. These biases appear to be selective, with mechanisms such as genetic bottleneck and genetic drift only playing a minor role [91].

\section{Disease Modelling}

Mitochondrial disease hPSC models provide a system to study disease gene- or mutation-related pathomechanisms in tissues relevant to the clinical phenotype. Ultimately, the long-term goal of these models would be to identify a phenotype in a clinically relevant cell type that could be used to validate efficacy of targeted treatments, or for use in highthroughput treatment trials [94-96] (Figure 2).

There are now a wide range of endpoints that have been validated in terminally differentiated cell types to investigate the underlying cellular mechanisms of disease and efficiently identify targetable pathways. Many of these approaches can also be adapted to suit different cell types and even organoids at scale. The tissue specific nature of mitochondrial diseases means that mitochondrial function post-differentiation can be distinct to that from the undifferentiated stem cells or original fibroblast line, often greatly exaggerating any underlying defects [97]. Additionally, detailed transcriptomic and proteomic analyses can elucidate cellular compensation mechanisms and potential target pathways to inform downstream treatment studies $[98,99]$. Other approaches include microscopic visualization of key cellular features to determine a mutation's impact on cell structure or function [100]. For cardiomyocytes and neurons, electrophysiology can provide highly sensitive data to identify even subtle functional changes [101]. Calcium imaging can be particularly informative in the context of mitochondrial diseases, since calcium handling is a key role of mitochondria [102,103]. 


\section{Functional Studies}

Only two hESC models of mitochondrial diseases have been published to date $[104,105]$. The remaining hPSC lines we have included are either: (i) iPSCs reprogrammed from patient somatic cells, or (ii) control iPSC lines genetically edited to possess a mutation in a relevant mitochondrial disease gene (see Tables A1 and A2).

For the purposes of this review, we will highlight a selection of studies that have utilised hPSCs to generate clinically relevant cell types for investigation of tissue specific defects of mitochondrial diseases or for the screening of potential therapeutic treatments for mitochondrial diseases. We have focused on mitochondrial diseases for which multiple hPSC cell lines have been reported, with similar findings uncovered from the various publications. We have elected to exclude the extensive studies involving hPSC models of Friedreich's ataxia, caused by GAA triplet-repeat expansions in FXN, which have been reviewed elsewhere [106]. See Tables A3 and A4 for details regarding cell lines, controls, and functional outcomes from these hPSC-derived mitochondrial disease models, and others not specifically featured below. The studies selected used either isogenic controls or a pool of at least 3 non-isogenic controls (see Sections 3.1 and 3.2 for recommended guidelines), and/or involved multiple publications with complementary outcomes. Understandably, modelling of mitochondrial disease using hPSCs is still in its infancy and not all reported studies will meet these criteria.

\subsection{Barth Syndrome-TAFAZZIN}

Barth syndrome (OMIM\# 302060) is caused by mutations in TAFAZZIN. Tafazzin is responsible for the formation of mature cardiolipin (tetralinoleoyl cardiolipin; CL), an essential lipid found mainly in the mitochondrial inner membrane that stabilises multiple protein complexes for optimal function and mitochondrial health [107,108].

As cardiomyopathy is the primary cause of death, several Barth syndrome iPSC models to investigate pathomechanisms in iPSC-derived cardiomyocytes (iPSC-CMs) have been developed $[109,110]$. As in patient tissues, an immature cardiolipin isoform (monolysocardiolipin; MLCL) dominates in the patient iPSC-CMs, resulting in an imbalance of the MLCL:CL ratio $[107,109,111]$. Like previous studies in other Barth syndrome cellular models, the iPSC-CMs displayed structural remodelling of OXPHOS complexes, including recapitulation of a cardiac specific decrease in OXPHOS complex II (CII) observed in mouse models [110]. Due to these OXPHOS defects, the maximal oxygen consumption rate (OCR) in Barth syndrome iPSC-CMs was lower than controls, however, the basal respiration rate was increased $[103,109,110]$. This counterintuitive observation was suggested to be a result of $\mathrm{H}^{+}$leak across the inner membrane, and increased $\mathrm{F}_{1} \mathrm{~F}_{0}$ ATP synthase (complex V)-linked oxygen consumption, albeit generating ATP inefficiently [109]. As well, cardiac cells preferentially utilise fatty acids as their substrate of choice for ATP production, but retain the flexibility to use other substrates when available or compelled [112]. Due to the mitochondrial dysfunction, Barth syndrome iPSC-CMs undergo metabolic alterations, utilise less palmitate, and rely more on glycolysis for energy generation [113]. At the single cell level, quantification of sarcomeric regularity in Barth syndrome iPSC-CMs revealed sarcomeric disorganisation $[109,110]$, although this was resolved when cardiomyocytes were engineered to align in 3D [103]. Nevertheless, Barth syndrome iPSC-CMs possessed contractility defects compared to controls following electrical stimulation in both a $2 \mathrm{D}$ thin muscular film format [109] and in a 3D engineered heart tissue assay [103].

It is widely recognised that elevated levels of reactive oxygen species (ROS) resulting in lipid peroxidation are a likely contributor to the cardiomyopathy observed in Barth syndrome [114]. Notably, the mitochondrial targeting ROS scavenger MitoTEMPO was shown to reduce ROS levels and improve contractility defects of Barth syndrome iPSCCMs $[103,109]$. In addition, elevated ROS in Barth syndrome iPSC-CMs caused excessive activation of CaMKII, and downstream CaMKII-mediated phosphorylation of the ryanodine receptor (RYR2) at Ser2814 [103]. This led to increased diastolic $\mathrm{Ca}^{2+}$ leak across the sarcoplasmic reticulum, contributing to calcium homeostasis abnormalities and the 
contractility defects observed in Barth syndrome iPSC-CMs [103]. With encouraging results emerging from a recent clinical trial of Barth syndrome patients with elamipretide, these hPSC-CM models could prove useful for further validation studies of its therapeutic potential [115].

\subsection{DOA and Parkinson's Disease-OPA1}

Autosomal dominant heterozygous mutations in OPA1 (OMIM\# 605290) result in optic atrophy (DOA) [116,117]. OPA1 plays a prominent role in mitochondrial membrane fusion and is essential for cellular differentiation [118]. While OPA1 mutant iPSC-derived neural stem cells (iPSC-NSCs) and neural progenitor cells (iPSC-NPCs) can be generated relatively normally $[104,119]$, it is unsurprising that all reported OPA1 mutant hPSC lines encountered differentiation defects and/or increased cell death in the later stages of neural and retinal ganglion cell differentiation $[104,110,119,120]$. Additionally, reduced mitochondrial respiration and OXPHOS complex I (CI) related ATP synthesis defects were also common features of OPA1 mutant iPSC-derived dopaminergic neurons (iPSC-DANs) [119,120].

Like patient somatic cells [121], OPA1 mutant hPSCs displayed an increased accumulation of ROS and sensitivity to cell death, even at the pluripotent stage [104,110]. The addition of apoptosis- or necrosis-inhibiting factors in the early stages of differentiation were shown to be beneficial in improving the survival of neurons and avoiding neurodegeneration following prolonged culture [119].

In severe cases, neurodegeneration due to OPA1 mutations has been reported to contribute to Parkinson's disease [122]. A direct comparison between OPA1 DOA versus Parkinson's disease iPSC-DANs derived from related patients with the same mutations showed that increased mitochondrial fragmentation and cell death likely contributed to the more severe symptoms in the Parkinsonism model [120]. A microfluidic nigrostriatal pathway (a brain structure composed primarily of dopaminergic neurons) on-a-chip technique, consisting of iPSC-DANs and striatal medium spiny neurons, was developed to study functional synapse connections in the OPA1 Parkinson's disease model. It identified a progressive loss of dopaminergic neuron synaptic terminals due to decreased mitochondrial content and motility along the axons [123].

\subsection{PEO and Alpers Syndrome-POLG}

Mutations in POLG (OMIM\# 174763) are responsible for an array of mitochondrial disorders with neurological manifestations, including progressive external ophthalmoplegia (PEO) [124]. The effects of compound heterozygous POLG mutations resulting in autosomal recessive PEO were analysed using patient derived iPSC-NSCs [125] and iPSC-DANs [126]. Consistent with the prominent role played by POLG in mtDNA replication, mutant iPSCNSCs and iPSC-DANs displayed reduced mtDNA copy number and CI subunit expression, features of which were seen in neurons isolated from the patient brain tissues, but not iPSCs or fibroblasts $[125,126]$. Consequently, a reduction in the $\mathrm{NAD}^{+}: \mathrm{NADH}$ ratio was identified in POLG patient iPSC-NSCs compared to controls, while the undifferentiated patient iPSCs trended towards an increased $\mathrm{NAD}^{+}: \mathrm{NADH}$ ratio [125].

With disruptions in OXPHOS being touted as a major contributor to ROS production [127], POLG patient-derived iPSC-NSCs and iPSC-DANs showed increased ROS levels that could be improved following $\mathrm{N}$-acetylcysteine amide supplementation [125,126]. An increase in ROS was otherwise not detected in the patient iPSCs, while patient fibroblasts showed reduced ROS levels instead when compared to controls [125]. Reduced ATP levels were also seen in patient iPSCs, iPSC-NSCs, and fibroblasts, but not iPSC-DANs $[125,126]$. Such differences between cell types highlight the importance of utilising iPSC-derived clinically relevant cell types to replicate tissue specific defects for the purposes of therapeutic investigations.

In addition to neurological presentations, autosomal recessive mutations in POLG can lead to Alpers syndrome (OMIM\# 203700), characterized by liver failure, seizures, and neuronal degeneration [128]. Valproic acid (VA) is a common treatment for seizure 
disorders, however numerous patients with POLG mutations reportedly suffer from severe liver toxicity following VA administration. Hepatocyte-like cells generated from Alpers syndrome patient iPSCs (iPSC-Hep) displayed various mitochondrial defects (see Table A3) and were more prone to VA-induced apoptosis caused by increased ROS release due to the opening of the mitochondrial permeability transition pore (mPTP) [129]. This could be prevented by administering the MPTP inhibitor cyclosporine $\mathrm{A}$, or the antioxidants carnitine and N-acetylcysteine (NAC) [129].

\section{4. mtDNA Depletion Syndromes-DGUOK and RRM2B}

DGUOK, encoding mitochondrial deoxyguanosine kinase, is involved in mtDNA nucleotide synthesis. Biallelic mutations in this gene can cause mtDNA depletion syndrome 3 (MTDPS3; OMIM\# 251880), a condition associated with neurologic abnormalities and liver failure [130]. To identify prospective treatments for MTDPS3, DGUOK-deficient iPSC-Hep were generated from CRISPR-Cas9 gene-edited iPSCs [131]. In a separate study, DGUOK defects were investigated in patient derived iPSC-Hep and hepatocyte organoid models [132]. Compared to isogenic controls, DGUOK ${ }^{-/-}$iPSC-Hep displayed both reduced mtDNA copy number and lower expression of mtDNA encoded genes [131,132]. Mutant cells also displayed impaired mitochondrial respiration, including a significant reduction in basal OCR, maximal OCR, and ATP levels compared to controls, while extracellular lactate production (e.g., glycolysis) increased [131]. Furthermore, DGUOK ${ }^{-/}$iPSC-Hep showed increased susceptibility to iron overload-induced ferroptosis that could be rescued either by silencing of nuclear receptor co-activator 4 (NCOA4) or treatment with NAC [132].

A library of 2400 drugs was screened for increased cellular ATP levels in DGUOK ${ }^{-/-}$ iPSC-Hep to identify prospective treatments. From this screen, 15 drugs were identified to increase ATP levels by more than 20\% [131]. One drug in particular, nicotinamide adenine dinucleotide (NAD), not only improved ATP production, but also consistently increased the expression of the mtDNA encoded OXPHOS genes MT-ATP8 (CV), MT-CO1 (CIV), MTCYB (CIII), and MT-ND1 (CI). Furthermore, treatment with NAD restored mitochondrial morphology in DGUOK ${ }^{-/-}$iPSC-Hep, increased mitochondrial membrane potential and improved OXPHOS respiration to levels comparable to WT cells [131]. NAD treatment was shown to upregulate mitochondrial biogenesis through PGC1 $\alpha$ activation, as opposed to direct upregulation of mtDNA copy number $[131,133,134]$. The use of NAD in combination with other ATP elevating drug candidates acting on different pathways enhanced the improvement in ATP levels over NAD alone [131]. Notably, the authors demonstrated that NAD treatment has therapeutic potential for other mtDNA depletion syndromes, showing improved ATP levels in a $R R M 2 B^{-/-}$iPSC-Hep model generated by CRISPR-Cas9 gene editing [131]. RRM2B (OMIM\# 604712) encodes a subunit of the mitochondrial ribonucleotide reductase complex that catalyses the conversion of ribonucleoside diphosphates into deoxyribonucleoside diphosphates, and RRM2B mutations lead to MTDPS8A/8B with clinical features including a range of neurological symptoms and liver involvement.

\subsection{Leigh Syndrome}

Leigh syndrome (OMIM\# 256000), a progressive neurodegenerative disorder, is the most common paediatric onset mitochondrial disease. Mutations in more than 75 genes (both nDNA and mtDNA encoded) can result in Leigh syndrome [135]. Thus far, investigations have been reported for Leigh syndrome iPSC-derived neuronal cell types possessing mutations in: MT-ATP6 [98,136], MT-ND5 [102], NDUFS4 and SURF1 [137], and SCO2 [99].

\subsubsection{Complex IV Assembly Factors-SURF1 and SCO2}

Deficiency of OXPHOS complex IV (cytochrome $c$ oxidase; COX) accounts for approximately $15 \%$ of all Leigh syndrome diagnoses [138-140], with mutations in SURF1 being the most commonly reported [135]. There are three distinct intermediates formed during CIV assembly, with several assembly factors stabilising and supporting the process, including SURF1 and SCO2. SURF1 is part of the first assembly intermediate, the MITRAC 
(mitochondrial translation regulation assembly intermediate of cytochrome $c$ oxidase), in the inner mitochondrial membrane [141]. Mutations in SURF1 severely reduce the levels of fully assembled CIV and result in accumulation of these assembly intermediates [142,143]. In contrast, loss of SCO2 results in degradation of mtDNA encoded subunits (COXI and II) [144]. A metallochaperone, SCO2 aids the insertion of copper into COXII, supporting formation of the MT-CO2 module [145]. While mutations in SCO2 result in similarly decreased CIV biogenesis and have also been associated with Leigh(-like) syndrome [146,147], patients more commonly present with hypertrophic cardiomyopathy [144,148-150].

Inak et al. (2021) generated several SURF1 iPSC models of CIV-linked Leigh syndrome [99]. These included both patient derived iPSC lines (one with corresponding isogenic control), as well as CRISPR-Cas9 gene-edited lines homozygous for one of the patient mutations, derived from a healthy iPSC control (Table A1). By modelling the same SURF1 mutation in two different genetic backgrounds, any compensatory effects resulting from the patients nuclear or mitochondrial makeup could be investigated [151]. Neural differentiation of the SURF1-iPSC lines revealed that loss of SURF1 negatively impacts both commitment and function as early as the neural progenitor stage. iPSC-NPCs exhibited decreased neurite branching, neurite length, maximal respiration, and ATP-linked respiration. Similar defects were observed in iPSC-NPCs derived from two NDUFS4 ${ }^{-/}$iPSC lines (OXPHOS complex I subunit; Table A1), supporting the decreased branching and neurite length as a broader Leigh syndrome phenotype rather than being gene-specific [99]. Further differentiation of the SURF1 lines to iPSC-derived neurons (iPSC-DNs; primarily dopaminergic) exacerbated these defects and showed decreased spiking and postsynaptic activity compared to isogenic controls. In a 3D neural organoid system, loss of SURF1 resulted in small poorly organised structures with significantly fewer $\mathrm{TUJ}^{+}, \mathrm{MAP}^{+}$, and $\mathrm{SYP}^{+}$neurons by day 90. Single cell transcriptomic analyses of SURF1 iPSC-DNs and neural organoids indicated an imbalance between proliferation and differentiation that disrupts normal neuronal maturation [99].

A range of mitochondrial targeted treatment strategies to improve OXPHOS function were trialled in the SURF1 iPSC-NPCs and -DNs with varying levels of success [99]. Hypoxia, which was shown to be beneficial in mouse models of NDUFS4 ${ }^{-/}$Leigh syndrome [152-154], resulted in increased glycolysis and exacerbated the neuronal outgrowth phenotypes in the SURF1 neurons. While metabolic manipulations (e.g., increased glucose and pyruvate supplementation) and treatment with ROS-scavengers (NAC or alphatocotrienol; AT3; EPI-743) marginally reduced glycolysis, they failed to improve cell morphology or mitochondrial function. Transcriptomic data from the SURF1 iPSC-DNs and neural organoids suggested expression of PPARGC1A was significantly reduced, therefore treatment with bezafibrate was trialled [99], which has previously been shown to activate peroxisome proliferator-activated receptor (PPAR) and pharmacologically upregulate PGC $1 \alpha$ driven mitochondrial biogenesis in iPSC-NPCs [155]. Treating the SURF1 iPSC-NPCs with $400 \mu \mathrm{M}$ bezafibrate resulted in increased mtDNA copy number, reduced expression of pluripotency and proliferation markers, and improved neuronal outgrowth and morphology (Table A3) [99].

Crucially, bezafibrate treatment allowed the SURF1-neurons to undergo the metabolic switch from glycolysis to OXPHOS and nearly ameliorated all mitochondrial functional defects, supporting bezafibrate as a possible therapeutic option for SURF1-related Leigh syndrome [3,99]. However, it is unclear if its effectiveness depends on the timing of the treatment [155], and a recent study on a cohort of six patients with MT-TL1 (m.3243A > G) mutations causing mitochondrial myopathy showed bezafibrate treatment was minimally effective at increasing mitochondrial biogenesis in patient skeletal muscle [156], and instead led to dose-dependent increases in mitochondrial disease biomarkers FGF-21 and GDF15 [156-158]. Therefore, mitochondrial biogenesis may not be effective for all mitochondrial diseases and will require further investigations to resolve when during development it could have the most impact. 
For SCO2, two iPSC lines were generated along with three healthy non-isogenic controls (Table A1), although most of the functional analyses only included one of these control lines [137]. Since mutations in $\mathrm{SCO} 2$ are predominantly associated with cardiomyopathy, functional studies of SCO2 iPSCs have so far been limited to iPSC-CMs. Both SCO2 mutant lines displayed arrhythmic contractility resulting from significant underlying calcium handling defects, supported by their attenuated response to ionotropic interventions (isoproterenol, angiotensin-II, and increased extracellular calcium) and delayed recovery following caffeine exposure. Nonetheless, significant progressive mitochondrial ultrastructural defects were only observed in the $\mathrm{SCO}_{2}{ }^{\mathrm{G} 193 \mathrm{~S}}$ mutant. It was proposed that the underlying defects in OXPHOS lead to an ATP deficit [149,159], which affects storage and handling of calcium by the sarcoplasmic reticulum and cardiomyocyte contractility [137]. Therefore, treatments targeting mitochondrial function or biogenesis could improve ATP production to support normal contractility in SCO2 mutant iPSC-CMs $[3,160]$. The benefits of bezafibrate treatment seen in the SURF1 hPSC models support this as a treatment option for SCO2 iPSC-CMs. Likewise, differentiation of these CIV deficiency hPSC models into similar cell types (e.g., cardiomyocytes or neurons) could provide insight into shared pathogenic pathways.

\subsubsection{MT-ATP6}

Several mtDNA mutations affecting MT-ATP6, a mtDNA encoded OXPHOS complex $\mathrm{V}$ subunit, have been associated with Leigh syndrome. Models reported so far include patient iPSCs possessing a homoplasmic m.9185T > C mutation differentiated into NPCs [98], and studies of homoplasmic m.8993T > G mutations in iPSC-DNs [136]. For both models, comparison to an array of non-isogenic controls was used.

In addition to reduced ATP production $[98,136]$, both mutant iPSC-NPCs and iPSCDNs displayed an increase in mitochondrial membrane potential (MMP) $[98,136]$. This mitochondrial hyperpolarization was not observed in MT-ATP6 m.9185T > C mutant fibroblasts nor cybrid lines [98], although it was reported previously in MT-ATP6 m.8993T > G cybrid models [161-164]. While the m.8993T $>$ G iPSC-NPCs were able to compensate for reduced ATP levels through glycolysis, terminally differentiated m.8993T > G iPSC-DNs are incapable of doing so, likely due to a lack of hexokinase and lactate dehydrogenase enzymes, further exacerbating the ATP defect observed in these cells [136].

Global proteomic and transcriptomic analyses revealed that genes involved in calcium signalling and homeostasis were downregulated in mutant m.9185T > C iPSC-NPCs. As expected, these changes were not detected in mutant fibroblasts, nor the undifferentiated patient iPSCs [98]. Calcium imaging of m.9185T > C iPSC-NPCs revealed impaired calcium homeostasis. A reduction in calcium-induced calcium release following stimulation with glutamate, as well as reduced mitochondrial calcium release following MMP depolarization, was also observed [98].

Taking advantage of the increased MMP phenotype observed in the m.9185T > C NPCs, 130 FDA-approved drugs were tested to identify compounds that would ameliorate this defect [98]. This screen identified avanafil as a compound that resulted in partial depolarization of the MMP. However, avanafil treatment did not improve ATP production, nor calcium-induced cytosolic calcium release. Nevertheless, overnight treatment with avanafil did improve mitochondrial calcium release in mutant NPCs and neurons upon MMP depolarization [98]. In the m.8993T > G iPSC-DANs, targeted treatment with rapamycin improved ATP production, reduced aberrant AMP-activated protein kinase activation, and decreased susceptibility to glutamate overdose toxicity [136].

\section{6. $L H O N$}

Leber hereditary optic neuropathy (LHON; OMIM\# 535000) is a mitochondrial disorder typically caused by homoplasmic mtDNA complex I subunit mutations.

Initial studies in a LHON iPSC model carrying homoplasmic double mtDNA mutations in MT-ND1 and MT-ND6 determined that their differentiation efficiency to retinal 
ganglion cells (iPSC-RGCs) was unaffected, but apoptosis was more prominent in these cells when compared to both a non-isogenic control and a cybrid corrected isogenic control [64]. Furthermore, in LHON patient iPSC-RGCs carrying a m.11778G > A MT-ND4 mutation, optic vesicles derived from the LHON iPSCs were smaller, with a notable difference in the appearance of the neuroblastic layer compared to controls [101]. Additionally, LHON iPSC-RGCs possessed shorter neurites, and formed fewer connections with neighbouring RGC bundles, while mitochondrial motility was also impaired [165]. NAC treatment was able to reduce ROS and improve mitochondrial motility and survival of m.11778G $>$ A LHON iPSC-RGCs [166]. However, it is unclear if the differentiation defects were a direct manifestation of mitochondrial dysfunction (Table A4) or are linked to the increased apoptosis $[64,166]$. Additionally, the use of non-isogenic controls makes it difficult to assign phenotypes directly to the m.11778G > A MT-ND4 variant [101,165]. Nonetheless, glutamate uptake was compromised in m.11778G > A LHON iPSC-RGCs. Changes in the expression levels and binding of $\alpha$-amino-3-hydroxy-5-methylisoxazole-4-propionic acid (AMPA) receptor and downstream scaffold proteins involved in glutaminergic synapse signalling were detected in mutant iPSC-RGCs, both in the presence and absence of glutamate stimulation [101].

\subsection{MELAS-MT-TL1}

Mutations in the mtDNA MT-TL1 gene, which encodes tRNA-leucine, account for a large proportion of patients with mitochondrial encephalomyopathy, lactic acidosis, and stroke-like episodes (MELAS; OMIM\# 540000) [167].

In initial studies, iPSCs were generated possessing high MT-TL1 m.3243A > G mutation levels $(\sim 80 \%)$, with mitoTALENs used to eliminate the mutant mtDNA, thereby generating an isogenic control (see Section 3.1.2) [80]. Compared to the isogenic control, mutant iPSCNPCs displayed respiration defects (Table A4), as well as differentiation abnormalities in the later stages of neuronal differentiation after NPC formation [80,97]. The cells failed to differentiate into motor neurons, while spinal cord organoids appeared to possess shorter neurite outgrowths [168]. This was shown to result from aberrant hyperactive Notch signalling, likely a direct consequence of the m.3243A > G mutation, as general CI inhibition by rotenone treatment also induced similar Notch signalling abnormalities [168]. The differentiation and morphological defects were rescued following quenching of Notch signalling using the inhibitor DAPT [168]. In similar studies, cortical excitatory neurons with variable heteroplasmy of the MT-TL1 m.3243A > G mutation were generated from patient iPSCs [97]. Cells with WT homoplasmy were used as an isogenic control, in addition to non-isogenic control lines. Neurons with high m.3243A > G heteroplasmy levels $(>65 \%)$ displayed similar mitochondrial respiration defects to those observed in iPSC-NPCs [97]. Morphologically, mutant neurons were shorter, and possessed fewer branch points and synaptic terminals at the single cell level. Mitochondrial content along the neuronal axons was also lower compared to controls. Interestingly, in m.3243A > G iPSC-neurons with a high mutant load $(>80 \%), \mathrm{CI}$ appeared to be actively sequestered into autophagosomes and cleared by mitophagy during further neuronal differentiation, contributing to CI deficiency in these neurons [21].

At the network level, spontaneous neuronal activity recorded by multi-electrode array indicated that neurons with high m.3243A $>$ G heteroplasmy levels had abnormal electrophysiological properties: reduced mean firing rate, reduced network burst rates, and increased random spike events outside of network bursts compared to controls [97]. In comparison, neurons with intermediate heteroplasmy levels ( 30\%) were relatively normal, indicative of the threshold effect for mtDNA mutations.

To specifically investigate the pathomechanisms causing stroke-like episodes in MELAS [169], MELAS-iPSCs (generated by [80]) were differentiated into endothelial cells (iPSC-ECs) and compared against the mitoTALEN corrected isogenic control [48]. In addition to reduced differentiation efficiency and poor endothelial tube formation, m.3243A $>\mathrm{G}$ iPSC-ECs were found to be pro-atherogenic and pro-inflammatory, expressing high levels 
of ROS and consequently increased oxidation of low-density lipoprotein (LDL). Mutant cells expressed increased levels of 'pro-adhesive' VCAM-1 isoform b, priming them for an inflammatory response and suggesting MELAS may have an atherosclerosis-like pathology. Even unstimulated, these iPSC-ECs showed more than 2-fold greater monocyte adhesion and the adhered monocytes expressed increased IL-8, setting the stage for proinflammatory niche formation [48]. Supporting the potential of hPSC models for preclinical identification of promising therapeutic options, treatment of MELAS iPSC-ECs with antioxidants CoQ10, Vitamin C, and edaravone (FDA approved for treatment of amyotrophic lateral sclerosis [170]), improved endothelial tube formation, as well as reduced ROS and inflammation levels [48].

\section{Conclusions}

It is clear from the publications highlighted here that hPSC models of mitochondrial disease recapitulate key aspects of human disease phenotypes in vitro and provide tissue specific insights into disease pathomechanisms. However, the validation approaches employed need to be sufficiently robust to detect any inconsistencies between the mutant and controls resulting from the hPSC generation process $[75,85]$. Additionally, the importance of isogenic controls cannot be overstated when assigning pathogenicity to a given genetic variant, and it is entirely possible that subtle changes could be overlooked with pooled controls [59]. From the studies we have identified, 57\% of the cell lines reported (114 in total) provided complete validation information including pluripotency, differentiation potential, and karyotype, with $40 \%$ of all iPSC lines (112 in total) also including lineage validation. Furthermore, of the 61 separate cell lines ( $54 \%$ of total) that underwent functional analyses, only $18 \%$ exclusively used isogenic controls, while a further $23 \%$ included isogenic controls alongside non-isogenic, and $25 \%$ made comparisons against at least 3 pooled non-isogenic controls.

For mitochondrial diseases in particular, variation in heteroplasmy poses a significant challenge for mtDNA hPSC models [87], but is manageable for the purposes of treatment studies. Heteroplasmy often appears to remain stable following directed differentiation $[45,87,91]$. Therefore, it is practical to check heteroplasmy levels before and after differentiation to ensure they are within the phenotypic range for patients with the same mutation $[45,171,172]$. Additionally, use of mitochondrial targeted editing strategies like mitoTALENs and DdCBEs could help achieve a greater level of control prior to differentiation $[80,81,83]$.

The stem cell field is continuously improving differentiation protocols to generate increasingly mature cell types [173-175] and models that are more disease relevant (i.e., organoids) [176]. Basic differentiation protocols typically only produce cells with gene expression profiles equivalent to embryonic cells [177]. These systems often require some form of secondary enrichment to yield a pure population of the relevant cells [178], and/or maturation steps (either supplemental, environmental, mechanical, or a combination) to achieve a disease relevant developmental stage $[179,180]$. For example, some neuronal cell types may benefit from co-culture with glial cells to achieve functional maturity [181,182]. Cell maturity significantly impacts on mitochondrial content and morphology $[160,183]$. Therefore, it is important to consider the suitability of a differentiation and maturation technique for any desired endpoints. Although organoid models may be more relevant, they may limit throughput due to added complexity of the culture format and a limited number of compatible assays $[37,184]$. They can also add additional complexity when it comes to dosing, penetration, and consistency between replicates due to the presence of multiple cell types in varied proportions $[185,186]$. Therefore, studies may require a mixture of 2D and 3D models depending on the required throughput and the disease relevant cell types.

Overall, mitochondrial disease hPSC models remain a promising option for mechanistic and therapeutic investigations, with a large number of models already generated having significant untapped potential (69 nDNA/27 different genes: 45 mtDNA/10 differ- 
ent genes and 4 large deletions) (Tables A1 and A2). However, some of the preliminary functional analyses from these models have failed to provide any disease specific pathomechanistic insights above those that could be, or have already been, observed with other more common human cellular models (e.g., fibroblasts; Tables A3 and A4). It is also evident that there are some fundamental roadblocks in progressing from cell line generation to the therapeutic testing stages of these disease models, as only two publications ( $1 \mathrm{nDNA}: 1 \mathrm{mtDNA}$ ) performed large scale intervention screens on differentiated cells $[98,131]$. Several studies (9 nDNA: 4 mtDNA) were able to perform more targeted screens using fewer than 6 compounds, with many only trialling a single compound after identifying a key pathway (Tables A3 and A4). This is indicative of the challenges associated with obtaining sufficient differentiated cells for screening, maintaining the purity of the target cell population, and achieving the highest possible maturity for a given cell type [187]. Another key hurdle to drug screens is the need for functional endpoints that provide sufficiently robust disease-relevant phenotypes to draw conclusive results [188]. Transcriptomics and other "omics" approaches, particularly in combination (i.e., multiomics), have the potential to provide a more complete picture of where and how processes are being regulated in a disease state [189]. These studies could aid pathway identification in differentiated cell types to inform downstream drug screens and elucidate disease specific cellular mechanisms, with some mitochondrial disease hPSC models reporting these data already (Tables A3 and A4) $[48,65,98,99,104,119,190,191]$. Despite the hurdles to screening, feasibility has been shown in some model systems and these approaches could be adapted to other terminally differentiated cell types $[98,131]$. Given the pace of hPSC development, it is likely that these hPSC models will be increasingly deployed to investigate tissue specific disease mechanisms and to screen for promising candidate drug treatments for mitochondrial disease. For mitochondrial diseases, where the clinical and genetic heterogeneity means there will likely be no one-size-fits-all treatment, these models have great potential to elucidate a range of treatment approaches suitable for downstream clinical trials.

Author Contributions: Conceptualization, C.L.M., Y.C.L., D.R.T. and A.E.F.; writing-original draft preparation, C.L.M. and Y.C.L.; writing-review and editing, C.L.M., Y.C.L., D.A.E., D.R.T. and A.E.F.; visualization, C.L.M. and Y.C.L.; supervision, D.A.E., D.R.T. and A.E.F. All authors have read and agreed to the published version of the manuscript.

Funding: The authors acknowledge support from the Mito Foundation (C.L.M., Y.C.L., D.R.T., A.E.F.) and Australian National Health and Medical Research Council (NHMRC) (GNT1155244, 1107094, 1164479, 1113531; D.A.E., D.R.T.). D.A.E. receives support from The Kids Cancer Project, Stafford Fox Foundation and The Royal Children's Hospital Foundation. Supported by the Victorian Government's Operational Infrastructure Support Program and NHMRC Independent Research Institute Infrastructure Support Scheme (IRIISS).

Acknowledgments: All figures were generated using BioRender.com.

Conflicts of Interest: The authors declare no conflict of interest. The funders had no role in the design of the study; in the collection, analyses, or interpretation of data; in the writing of the manuscript, or in the decision to publish the results.

\section{Appendix A}

Table A1 (nDNA models) and Table A2 (mtDNA models) are intended as a resource summarising hPSC models of mitochondrial disease that have been generated to date for the purposes of disease modelling (i.e., directly or secondarily affecting OXPHOS function). Not included are lines generated for other purposes (e.g., studying cell therapies, diabetes, aging), or those generated involving genes linked to other metabolic pathways or mitochondrial-linked disorders with specific phenotypes. We have attempted to compile a comprehensive list but acknowledge we may have overlooked some relevant hPSC models. For many of the included lines, isogenic control iPSC or parental iPSC lines may have been specifically generated or occurred incidentally (e.g., low/no mutant heteroplasmy), but 
these are not listed in this table. For mtDNA lines with multiple clones generated, all clones subjected to some form of validation (e.g., pluripotency, etc) with $>30 \%$ mtDNA mutant load have been included, noting however that the mutant threshold required to manifest a biochemical defect can vary widely for each individual mtDNA mutation. For some of the reported mtDNA models, the pathogenicity of the reported variants is uncertain, as indicated. We have not included the cell line generated in [192] and the reported variant m.4216T > C in [65], due to available population data (MITOMAP and gnomAD 3.1) that indicates the mtDNA variants are of questionable pathogenicity (i.e., high population frequency and/or mtDNA haplotype marker). 
Table A1. nDNA models.

\begin{tabular}{|c|c|c|c|c|c|c|c|c|c|c|}
\hline Gene & Disease & Cell Line ID & Mutation $^{a}$ & $\begin{array}{l}\text { Cell Line } \\
\text { Origin } b\end{array}$ & $\begin{array}{c}\text { Gene Editing } \\
\text { /Reprogramming }\end{array}$ & Pluripotency & $\begin{array}{l}\text { Trilineage } \\
\text { Potential }\end{array}$ & $\begin{array}{c}\text { Karyotype; } \\
\text { Lineage Validation }^{c}\end{array}$ & $\begin{array}{l}\text { Mycoplasma } \\
\text { Check }\end{array}$ & Ref. \\
\hline AARS2 & COXPD8 & LUMCi024-A & $\begin{array}{c}\text { p.[(R958*)]; } \\
{[(\mathrm{R} 592 \mathrm{~W}) ;(\mathrm{V} 730 \mathrm{M})]}\end{array}$ & M; 4 days; Fib & Sendai virus & $\begin{array}{l}\text { Morphology; IF; } \\
\text { FACS }\end{array}$ & $\begin{array}{c}\text { EB } \\
\text { differentiation }\end{array}$ & G-banding; Yes & Yes & [193] \\
\hline AARS2 & COXPD8 & LUMCi025-A & $\begin{array}{c}\text { p.[(R958*)]; } \\
{[(\mathrm{R} 592 \mathrm{~W}) ;(\mathrm{V} 730 \mathrm{M})]}\end{array}$ & M; 1 day; Fib & Sendai virus & $\begin{array}{l}\text { Morphology; IF; } \\
\text { FACS }\end{array}$ & $\begin{array}{c}\mathrm{EB} \\
\text { differentiation }\end{array}$ & G-banding; Yes & Yes & [193] \\
\hline ACO2 & DOA & IISHDOi006-A & p. $[(\mathrm{E} 667 \mathrm{~K})] ;[=]$ & $\mathrm{M} ; 30 \mathrm{yr} ; \mathrm{Fib}$ & Sendai virus & $\begin{array}{l}\text { Morphology; AP; } \\
\text { qPCR; IF }\end{array}$ & $\begin{array}{c}\text { EB } \\
\text { differentiation }\end{array}$ & G-banding; Yes & Yes & [194] \\
\hline AIFM1 & AN & CPGHi003-A & p.[(R422Q)];[0] & M; 49 yr; PBMC & $\begin{array}{l}\text { Episomal } \\
\text { vectors }\end{array}$ & $\begin{array}{l}\text { Morphology; } \\
\text { RT-qPCR; IF }\end{array}$ & $\begin{array}{c}\text { EB } \\
\text { differentiation }\end{array}$ & G-banding; Yes & Yes & [195] \\
\hline$A T A D 3 A$ & HSP & $\begin{array}{l}\text { HEL142 }(2 \\
\text { clones) }\end{array}$ & p.[(G355D)];[=] & F; 35 yr; Fib & $\begin{array}{l}\text { Episomal } \\
\text { vectors }\end{array}$ & qPCR; IF & $\mathrm{N} / \mathrm{D}$ & $\mathrm{N} / \mathrm{D}$ & N/D & [196] \\
\hline$C 1 Q B P$ & COXPD & XACHi010-A & $\begin{array}{l}\text { p.[(L275F)]; } \\
{[(\mathrm{L} 275 \mathrm{~F})]}\end{array}$ & M; 14 yr; PBMC & Sendai virus & $\begin{array}{l}\text { Morphology; IF; } \\
\text { FACS }\end{array}$ & $\begin{array}{c}\text { Trilineage } \\
\text { differentiation }\end{array}$ & G-banding; Yes & Yes & [197] \\
\hline COQ2 & MSA-C & $\begin{array}{l}\text { MSA_A (3 } \\
\text { clones) }\end{array}$ & $\begin{array}{l}\text { p.[(R387*)]; } \\
{[(\mathrm{V} 393 \mathrm{~A})]}\end{array}$ & M; 61 yr; PBMC & $\begin{array}{l}\text { Episomal } \\
\text { vectors }\end{array}$ & Morphology; IF & Teratoma & G-banding; N/D & $\mathrm{N} / \mathrm{D}$ & [198] \\
\hline COQ4 & $\begin{array}{l}\text { CoQ10 } \\
\text { deficiency }\end{array}$ & $\begin{array}{l}\text { CQ4-Ipsc (4 } \\
\text { clones) }\end{array}$ & p.[(E161D)];[=] & F; 4 yr; Fib & Sendai virus & $\begin{array}{l}\text { Morphology; AP; } \\
\text { RT-qPCR; IF; FACS; } \\
\text { hypomethylation }\end{array}$ & Teratoma & G-banding; Yes & Yes & {$[199,200]$} \\
\hline СOX6A2 & $\begin{array}{c}\text { CIV } \\
\text { deficiency }\end{array}$ & WAe009-A-47 & $\begin{array}{l}\text { p.[A16Lfs*18]; } \\
\text { [A16Lfs*18] }\end{array}$ & F; hESC-WA09 & $\begin{array}{l}\text { CRISPR-Cas9 } \\
\text { induced } \\
\text { mutation }\end{array}$ & $\begin{array}{c}\text { Morphology; } \\
\text { RT-qPCR; IF; FACS }\end{array}$ & Teratoma & G-banding; Yes & Yes & [105] \\
\hline DGUOK & MTDPS3 & $\begin{array}{c}\text { DGUOK }^{\Delta 14 / \Delta 5} \\
\text { iPSC }^{2}\end{array}$ & $\begin{array}{c}\text { p.[W166*]; } \\
\text { [H167Lf*213] }\end{array}$ & M; iPS-SV20 & $\begin{array}{l}\text { CRISPR-Cas9 } \\
\text { induced } \\
\text { mutation }\end{array}$ & $\mathrm{N} / \mathrm{D}$ & $\mathrm{N} / \mathrm{D}$ & $\mathrm{N} / \mathrm{D}$ & $\mathrm{N} / \mathrm{D}$ & [131] \\
\hline DGUOK & MTDPS & Patient 1 & p.[F256*];[F256*] & F; 2 mo; Fib & Retrovirus & Morphology & $\mathrm{N} / \mathrm{D}$ & G-banding; N/D & $\mathrm{N} / \mathrm{D}$ & [132] \\
\hline DGUOK & MTDPS & Patient 2 & $\begin{array}{c}\text { [p.A2S; c.591G > A] } \\
{[\text { c. } 142+1 G>A]}\end{array}$ & $\mathrm{M} ; 2$ mo; Fib & Retrovirus & Morphology & $\mathrm{N} / \mathrm{D}$ & G-banding; N/D & $\mathrm{N} / \mathrm{D}$ & [132] \\
\hline DNAJC19 & DCMA & Patient 1 & $\begin{array}{l}\text { c. }[130-1 \mathrm{G}>\mathrm{C}] \\
{[130-1 \mathrm{G}>\mathrm{C}]}\end{array}$ & F; 1.5 yr; PBMC & Sendai virus & IF & $\mathrm{N} / \mathrm{D}$ & SNP microarray; N/D & $\mathrm{N} / \mathrm{D}$ & [201] \\
\hline DNAJC19 & DCMA & Patient 2 & $\begin{array}{c}\text { c. }[130-1 \mathrm{G}>\mathrm{C}] \\
{[130-1 \mathrm{G}>\mathrm{C}]}\end{array}$ & M; 11 yr; PBMC & Sendai virus & IF & $\mathrm{N} / \mathrm{D}$ & SNP microarray; N/D & $\mathrm{N} / \mathrm{D}$ & [201] \\
\hline DNAJC19 & DCMA & LIBUCi001-A & $\begin{array}{c}\text { c. }[130-1 G>C] \\
{[130-1 G>C]}\end{array}$ & M; 8 yr; Fib & Sendai virus & $\begin{array}{l}\text { Morphology; IF; } \\
\text { FACS }\end{array}$ & $\begin{array}{c}\text { EB } \\
\text { differentiation }\end{array}$ & G-banding; Yes & Yes & [202] \\
\hline
\end{tabular}


Table A1. Cont.

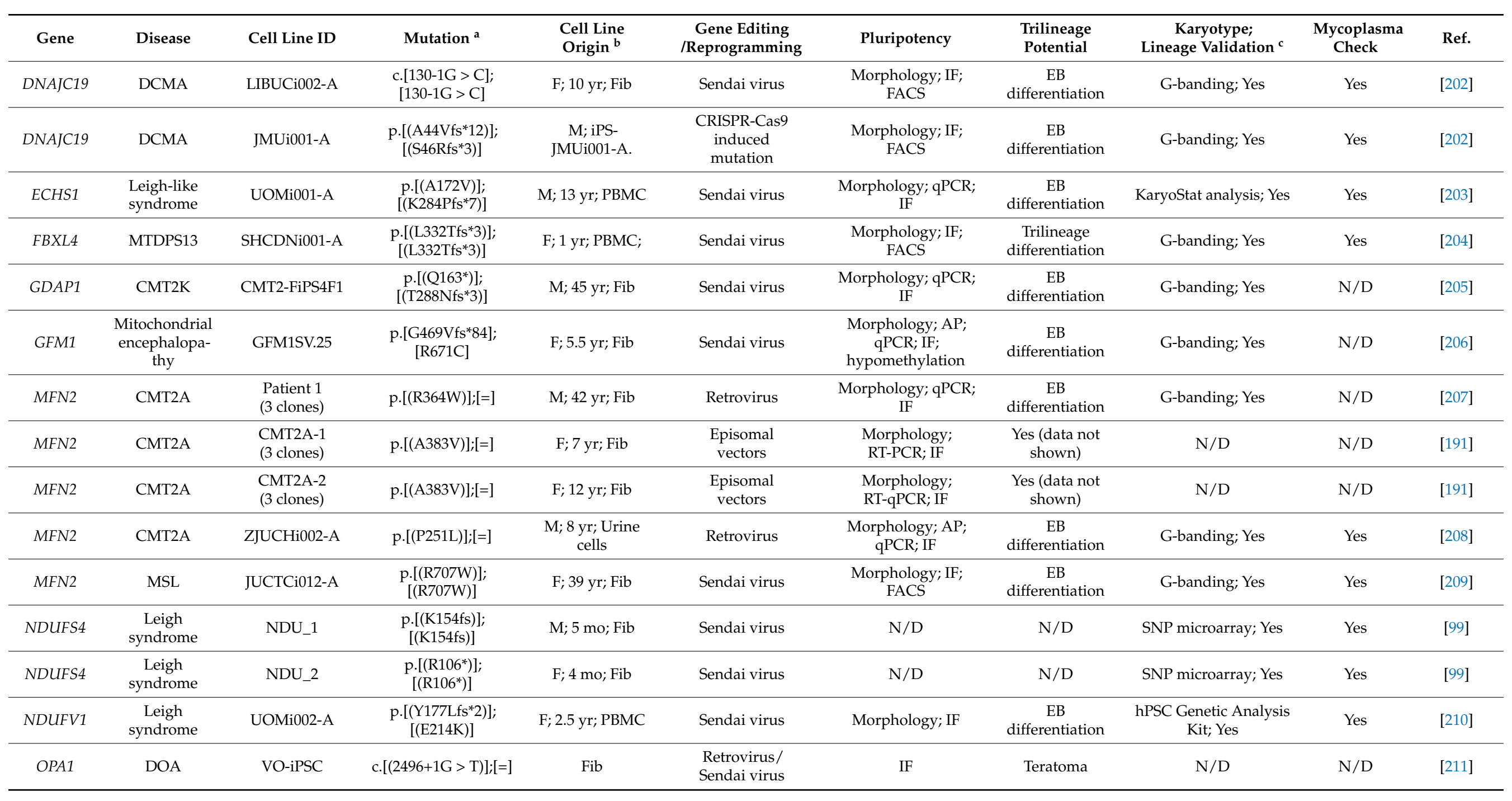


Table A1. Cont.

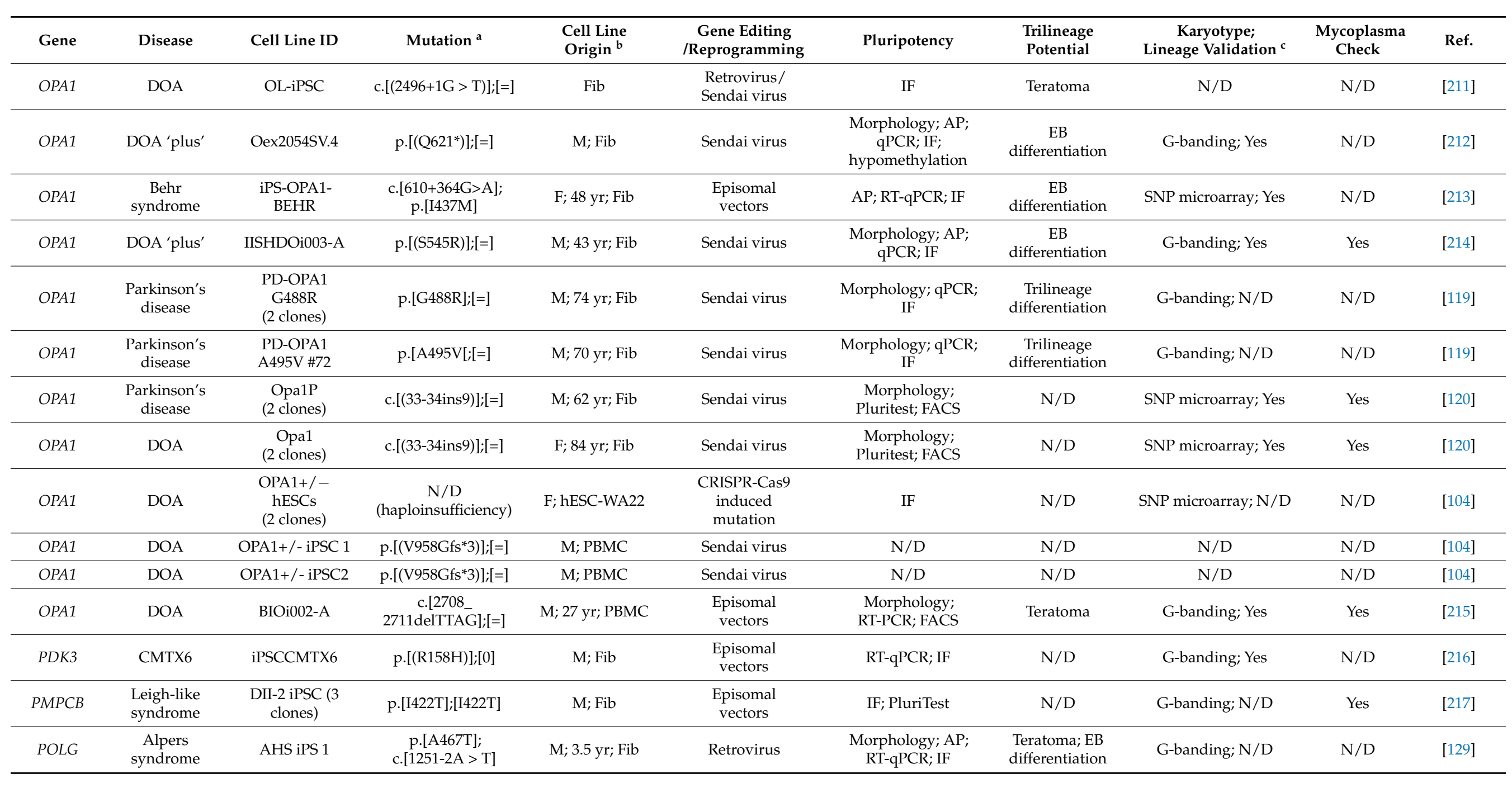


Table A1. Cont.

\begin{tabular}{|c|c|c|c|c|c|c|c|c|c|c|}
\hline Gene & Disease & Cell Line ID & Mutation $^{a}$ & $\begin{array}{l}\text { Cell Line } \\
\text { Origin } b\end{array}$ & $\begin{array}{c}\text { Gene Editing } \\
\text { /Reprogramming }\end{array}$ & Pluripotency & $\begin{array}{l}\text { Trilineage } \\
\text { Potential }\end{array}$ & $\begin{array}{c}\text { Karyotype; } \\
\text { Lineage Validation }^{c}\end{array}$ & $\begin{array}{l}\text { Mycoplasma } \\
\text { Check }\end{array}$ & Ref. \\
\hline POLG & $\begin{array}{l}\text { Alpers } \\
\text { syndrome }\end{array}$ & AHS iPS 2 & $\begin{array}{c}\text { p.[A467T]; } \\
\text { c.[3626_3629dup] }\end{array}$ & F; 2 yr; Fib & Retrovirus & $\begin{array}{l}\text { AP; Morphology; } \\
\text { RT-qPCR; IF }\end{array}$ & $\begin{array}{c}\text { Teratoma; EB } \\
\text { differentiation }\end{array}$ & G-banding; N/D & $\mathrm{N} / \mathrm{D}$ & [129] \\
\hline POLG & $\begin{array}{l}\text { PEO and } \\
\text { Parkinson's } \\
\text { disease }\end{array}$ & $\begin{array}{l}\text { CSC }-35 \\
\text { (3 clones) }\end{array}$ & p.[(Q811R)];[=] & F; 24 yr; Fib & Sendai virus & Morphology; AP; IF & $\begin{array}{c}\text { EB } \\
\text { differentiation }\end{array}$ & G-banding; Yes & $\mathrm{N} / \mathrm{D}$ & [190] \\
\hline POLG & PEO & $\begin{array}{c}\text { WS5A } \\
\text { (3 clones) }\end{array}$ & p.[W748S];[W748S] & F; Fib & Retrovirus & $\begin{array}{c}\text { Morphology; } \\
\text { RT-qPCR; IF; FACS; }\end{array}$ & $\begin{array}{l}\text { Hep, } \mathrm{CM} \text {, and } \\
\text { neuronal } \\
\text { differentiation }\end{array}$ & G-banding; N/D & Yes & {$[125,126]$} \\
\hline POLG & PEO & $\begin{array}{c}\text { CP2A } \\
\text { (2 clones) }\end{array}$ & $\begin{array}{l}\text { p.[A467T]; } \\
\text { [W748S] }\end{array}$ & $\mathrm{M} ; \mathrm{Fib}$ & Retrovirus & $\begin{array}{c}\text { Morphology; } \\
\text { RT-qPCR; IF; FACS }\end{array}$ & $\begin{array}{l}\text { Hep, } \mathrm{CM} \text {, and } \\
\text { neuronal } \\
\text { differentiation }\end{array}$ & G-banding; N/D & Yes & {$[125,126]$} \\
\hline$R R M 2 B$ & MTDPS8A/B & $\begin{array}{c}\mathrm{RRM}^{2} \mathrm{~B}^{-1-} \\
\text { iPSC }\end{array}$ & $\begin{array}{c}\text { p.[R36Sfs*55]; } \\
{\left[\mathrm{R}^{2} 6 \mathrm{Sfs}^{*} 55\right]}\end{array}$ & M; iPS-SV20 & $\begin{array}{l}\text { CRISPR-Cas9 } \\
\text { induced } \\
\text { mutation }\end{array}$ & $\mathrm{N} / \mathrm{D}$ & $\mathrm{N} / \mathrm{D}$ & $\mathrm{N} / \mathrm{D}$ & $\mathrm{N} / \mathrm{D}$ & [131] \\
\hline SAMHD1 & AGS & $\begin{array}{c}\text { hSAMHD1- } \\
\text { R290H+Q548X }\end{array}$ & p.[(R290H)];[(Q548*)] & $\mathrm{M} ; \mathrm{PBMC}$ & Sendai virus & FACS & $\begin{array}{c}\text { EB } \\
\text { differentiation }\end{array}$ & G-banding; Yes & $\mathrm{N} / \mathrm{D}$ & [220] \\
\hline $\mathrm{SCO} 2$ & $\begin{array}{c}\text { CIV } \\
\text { deficiency }\end{array}$ & SCO2G193S & $\begin{array}{l}\text { p.[(G193S)]; } \\
{[(\text { G193S)] }}\end{array}$ & M; 4 mo; Fib & Lentivirus & IF & Teratoma & G-banding; N/D & $\mathrm{N} / \mathrm{D}$ & [137] \\
\hline SCO2 & $\begin{array}{c}\text { CIV } \\
\text { deficiency }\end{array}$ & SCO2E140K & $\begin{array}{l}\text { p. }[(\mathrm{E} 140 \mathrm{~K})] ; \\
{\text { c. }[(17 \operatorname{ins}(19))]^{\mathrm{d}}}\end{array}$ & M; 13 wk; Fib & Lentivirus & IF & Teratoma & G-banding; N/D & $\mathrm{N} / \mathrm{D}$ & [137] \\
\hline SURF1 & $\begin{array}{c}\text { Leigh } \\
\text { syndrome }\end{array}$ & SURF1_Mut: S1 & $\begin{array}{c}\text { p.[(V177G)]; } \\
{[(\mathrm{V} 177 \mathrm{G})]}\end{array}$ & M; 9 yr; Fib & Sendai virus & RT-PCR; IF & $\begin{array}{c}\text { EB } \\
\text { differentiation }\end{array}$ & $\begin{array}{l}\text { SNP microarray and } \\
\text { G-banding; Yes }\end{array}$ & Yes & [99] \\
\hline SURF1 & $\begin{array}{l}\text { Leigh } \\
\text { syndrome }\end{array}$ & SURF1_Mut: S2 & $\begin{array}{l}\text { p.[(G257R)]; } \\
{[(\mathrm{G} 257 \mathrm{R})]}\end{array}$ & M; 20 mo; Fib & Sendai virus & RT-PCR; IF & $\begin{array}{c}\text { EB } \\
\text { differentiation }\end{array}$ & $\begin{array}{c}\text { SNP microarray, } \\
\text { G-banding and WGS; } \\
\text { Yes }\end{array}$ & Yes & [99] \\
\hline SURF1 & $\begin{array}{l}\text { Leigh } \\
\text { syndrome }\end{array}$ & $\begin{array}{l}\text { C1_Mut } \\
\text { (2 clones) }\end{array}$ & $\begin{array}{l}\text { p.[(G257R)]; } \\
{[(\mathrm{G} 257 \mathrm{R})]}\end{array}$ & F; iPS-XM001 & $\begin{array}{l}\text { CRISPR-Cas9 } \\
\text { induced } \\
\text { mutation }\end{array}$ & $\mathrm{N} / \mathrm{D}$ & $\mathrm{N} / \mathrm{D}$ & $\begin{array}{l}\text { SNP microarray; } \\
\text { Yes }\end{array}$ & Yes & [99] \\
\hline
\end{tabular}


Table A1. Cont.

\begin{tabular}{|c|c|c|c|c|c|c|c|c|c|c|}
\hline Gene & Disease & Cell Line ID & Mutation $^{a}$ & $\begin{array}{l}\text { Cell Line } \\
\text { Origin }{ }^{b}\end{array}$ & $\begin{array}{c}\text { Gene Editing } \\
\text { /Reprogramming }\end{array}$ & Pluripotency & $\begin{array}{l}\text { Trilineage } \\
\text { Potential }\end{array}$ & $\begin{array}{c}\text { Karyotype; } \\
\text { Lineage Validation }^{c}\end{array}$ & $\begin{array}{l}\text { Mycoplasma } \\
\text { Check }\end{array}$ & Ref. \\
\hline$T A Z$ & $\begin{array}{l}\text { Barth } \\
\text { syndrome }\end{array}$ & $\begin{array}{l}\text { TAZ10 } \\
\text { ( } 2 \text { clones) }\end{array}$ & p.[G197V];[0] & M; Fib & Lentivirus & $\begin{array}{l}\text { Morphology; AP; } \\
\text { RT-PCR; IF; } \\
\text { hypomethylation }\end{array}$ & $\begin{array}{l}\text { Teratoma; EB } \\
\text { differentiation }\end{array}$ & $\mathrm{N} / \mathrm{D}$ & $\mathrm{N} / \mathrm{D}$ & [221] \\
\hline$T A Z$ & $\begin{array}{l}\text { Barth } \\
\text { syndrome }\end{array}$ & $\begin{array}{l}\text { TAZ13 } \\
\text { (3 clones) }\end{array}$ & c. $[110-1 \mathrm{G}>\mathrm{C}] ;[0]$ & M; Fib & Lentivirus & $\begin{array}{l}\text { Morphology; AP; } \\
\text { RT-PCR; IF; } \\
\text { hypomethylation }\end{array}$ & $\begin{array}{c}\text { Teratoma; EB } \\
\text { differentiation }\end{array}$ & $\mathrm{N} / \mathrm{D}$ & $\mathrm{N} / \mathrm{D}$ & [221] \\
\hline$T A Z$ & $\begin{array}{l}\text { Barth } \\
\text { syndrome }\end{array}$ & $\begin{array}{l}\text { TAZ15 } \\
\text { (3 clones) }\end{array}$ & p.[R57L];[0] & M; Fib & Lentivirus & $\begin{array}{l}\text { Morphology; AP; } \\
\text { RT-PCR; IF; } \\
\text { hypomethylation }\end{array}$ & $\begin{array}{l}\text { Teratoma; EB } \\
\text { differentiation }\end{array}$ & $\mathrm{N} / \mathrm{D}$ & $\mathrm{N} / \mathrm{D}$ & [221] \\
\hline$T A Z$ & $\begin{array}{c}\text { Barth } \\
\text { syndrome }\end{array}$ & BTH-H & p.[(D173Tfs*12)];[0] & M; Fib & Retrovirus & $\begin{array}{l}\text { Morphology; } \\
\text { RT-qPCR; IF }\end{array}$ & Teratoma & $\begin{array}{l}\text { G-banding; } \\
\text { N/D }\end{array}$ & $\mathrm{N} / \mathrm{D}$ & [109] \\
\hline$T A Z$ & $\begin{array}{l}\text { Barth } \\
\text { syndrome }\end{array}$ & BTH-C & p.[(S110P)];[0] & $\mathrm{M} ; \mathrm{Fib}$ & Modified RNA & $\begin{array}{l}\text { Morphology; } \\
\text { RT-qPCR; IF }\end{array}$ & Teratoma & $\begin{array}{l}\text { G-banding; } \\
\text { N/D }\end{array}$ & $\mathrm{N} / \mathrm{D}$ & [109] \\
\hline$T A Z$ & $\begin{array}{l}\text { Barth } \\
\text { syndrome }\end{array}$ & $\begin{array}{l}\text { PGP1- } \\
\text { TAZ } \\
\text { (.517delG }\end{array}$ & p.[(D173Tfs*12)];[0] & M; iPS-PGP1 & $\begin{array}{l}\text { CRISPR-Cas9 } \\
\text { induced } \\
\text { mutation }\end{array}$ & $\begin{array}{l}\text { Morphology; } \\
\text { RT-qPCR; IF }\end{array}$ & Teratoma & $\begin{array}{l}\text { G-banding; } \\
\text { N/D }\end{array}$ & $\mathrm{N} / \mathrm{D}$ & [109] \\
\hline$T A Z$ & $\begin{array}{l}\text { Barth } \\
\text { syndrome }\end{array}$ & $\begin{array}{l}\text { PGP1- } \\
\text { TAZ }\end{array}$ & p.[(D173Efs)];[0] & M; iPS-PGP1 & $\begin{array}{l}\text { CRISPR-Cas9 } \\
\text { induced } \\
\text { mutation }\end{array}$ & $\begin{array}{l}\text { Morphology; } \\
\text { RT-qPCR; IF }\end{array}$ & Teratoma & $\begin{array}{l}\text { G-banding; } \\
\text { N/D }\end{array}$ & $\mathrm{N} / \mathrm{D}$ & [109] \\
\hline$T A Z$ & $\begin{array}{l}\text { Barth } \\
\text { syndrome }\end{array}$ & WMUi002-A & p.[(D173Efs)];[0] & $\begin{array}{l}\text { M; 6yr; urine } \\
\text { cells }\end{array}$ & Sendai virus & qPCR; IF & $\begin{array}{c}\mathrm{EB} \\
\text { differentiation }\end{array}$ & G-banding; Yes & Yes & [222] \\
\hline TRNT1 & $\mathrm{RP}$ & $\begin{array}{c}\text { P1 } \\
\text { (4 clones) }\end{array}$ & $\begin{array}{l}\text { p.[(E43del)]; } \\
{[(\text { S418Vfs })]}\end{array}$ & M; 19 yr; Fib & Sendai virus & $\begin{array}{l}\text { Morphology; } \\
\text { RT-PCR; IF }\end{array}$ & $\begin{array}{l}\text { Taqman mRNA } \\
\text { scorecard }\end{array}$ & G-banding; N/D & $\mathrm{N} / \mathrm{D}$ & [223] \\
\hline TRNT1 & $\mathrm{RP}$ & $\begin{array}{c}\text { P2 } \\
\text { (4 clones) }\end{array}$ & $\begin{array}{l}\text { p. }[(\mathrm{S} 418 \mathrm{Kfs})] ; \\
\text { c. }[609-26 \mathrm{~T}>\mathrm{C}]\end{array}$ & $\mathrm{M} ; 21 \mathrm{yr} ; \mathrm{Fib}$ & Sendai virus & $\begin{array}{l}\text { Morphology; } \\
\text { RT-PCR; IF }\end{array}$ & $\begin{array}{l}\text { Taqman mRNA } \\
\text { scorecard }\end{array}$ & G-banding; N/D & $\mathrm{N} / \mathrm{D}$ & [223] \\
\hline TRNT1 & $\mathrm{RP}$ & $\begin{array}{c}\text { P3 } \\
\text { (4 clones) }\end{array}$ & $\begin{array}{l}\text { p. }[(\mathrm{S} 418 \mathrm{Kfs})] ; \\
\text { c. }[609-26 \mathrm{~T}>\mathrm{C}]\end{array}$ & M; 18 yr; Fib & Sendai virus & $\begin{array}{l}\text { Morphology; } \\
\text { RT-PCR; IF }\end{array}$ & $\begin{array}{l}\text { Taqman mRNA } \\
\text { scorecard }\end{array}$ & G-banding; N/D & $\mathrm{N} / \mathrm{D}$ & [223] \\
\hline
\end{tabular}

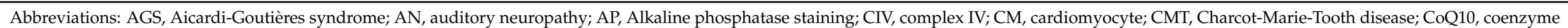

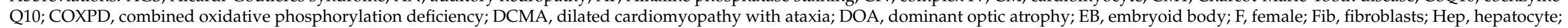

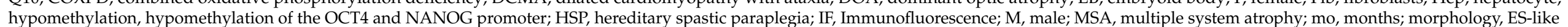

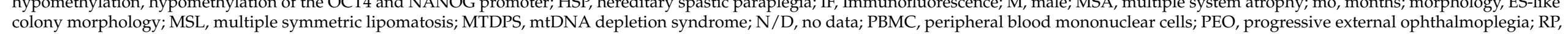

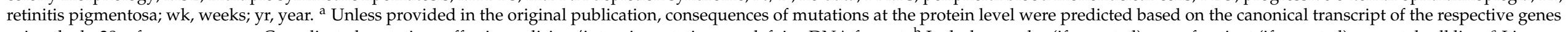

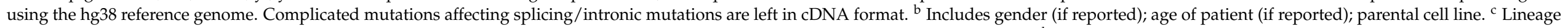

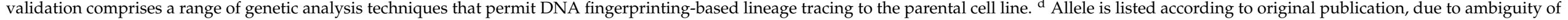
the reported variant. 
Table A2. mtDNA models.

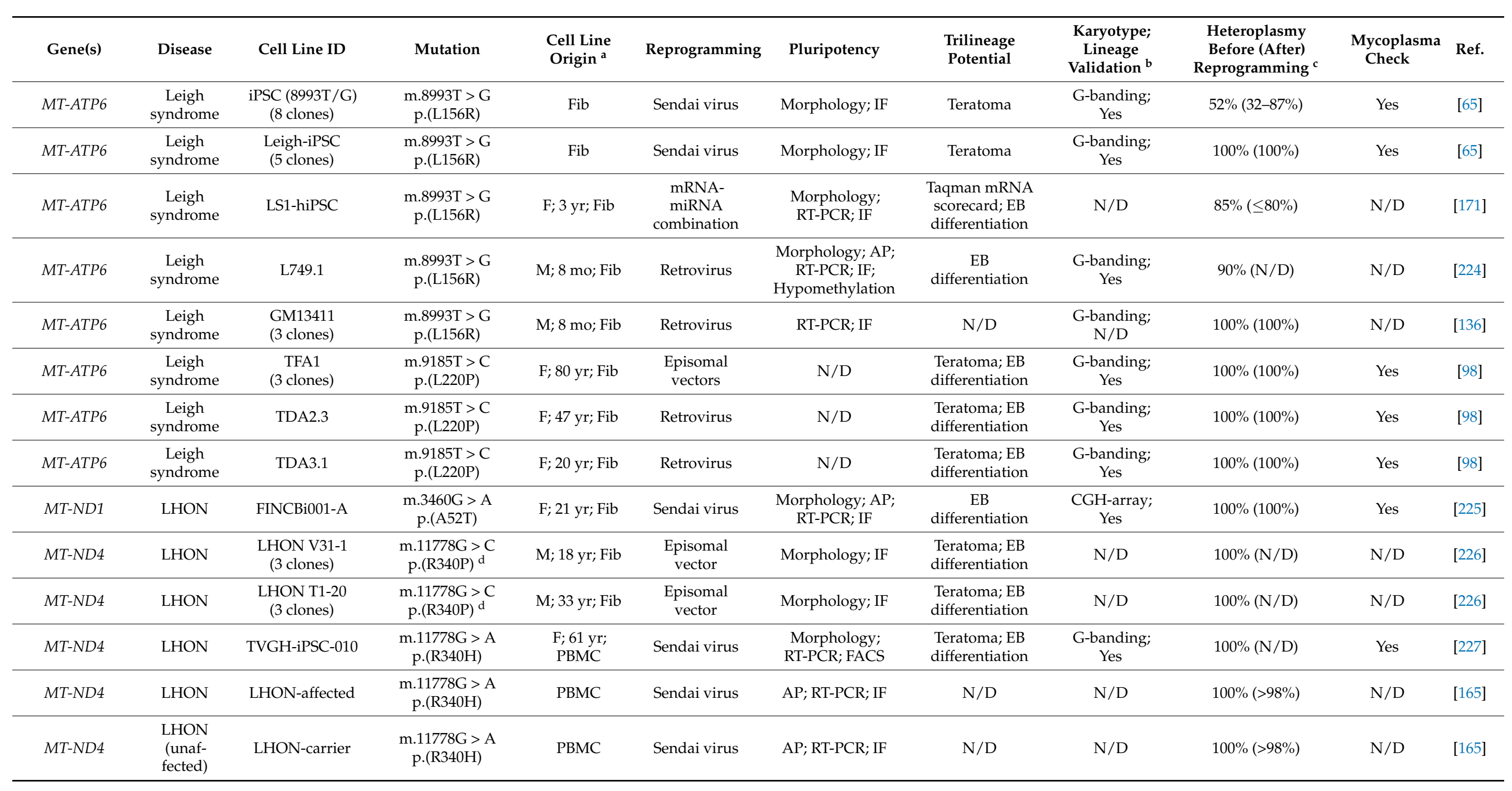


Table A2. Cont.

\begin{tabular}{|c|c|c|c|c|c|c|c|c|c|c|c|}
\hline Gene(s) & Disease & Cell Line ID & Mutation & $\begin{array}{l}\text { Cell Line } \\
\text { Origin }^{a}\end{array}$ & Reprogramming & Pluripotency & $\begin{array}{l}\text { Trilineage } \\
\text { Potential }\end{array}$ & $\begin{array}{l}\text { Karyotype; } \\
\text { Lineage } \\
\text { Validation } b\end{array}$ & $\begin{array}{c}\text { Heteroplasmy } \\
\text { Before (After) } \\
\text { Reprogramming }\end{array}$ & $\begin{array}{l}\text { Mycoplasma } \\
\text { Check }\end{array}$ & Ref. \\
\hline MT-ND4 & LHON & LHON-iPSC & $\begin{array}{c}\text { m.11778G > A } \\
\text { p. }(\mathrm{R} 340 \mathrm{H})\end{array}$ & $\begin{array}{l}\text { M; } 18 \text { yr; } \\
\text { PBMC }\end{array}$ & Sendai virus & $\begin{array}{l}\text { Morphology; } \\
\text { RT-qPCR }\end{array}$ & $\mathrm{N} / \mathrm{D}$ & $\mathrm{N} / \mathrm{D}$ & $\mathrm{N} / \mathrm{D}$ & $\mathrm{N} / \mathrm{D}$ & [101] \\
\hline $\begin{array}{l}\text { MT-ND6 and } \\
\text { MT-ND1 }\end{array}$ & $\begin{array}{l}\text { 'LHON } \\
\text { plus' }\end{array}$ & $\begin{array}{l}\text { LHON Q1-4 } \\
\text { (3 clones) }\end{array}$ & $\begin{array}{c}\mathrm{m} .14484 \mathrm{~T}>\mathrm{C} \\
\text { p. }(\mathrm{M} 64 \mathrm{~V}) \text { and } \\
\mathrm{m} .4160 \mathrm{~T}>\mathrm{C} \\
\mathrm{p} .(\mathrm{L} 285 \mathrm{P})\end{array}$ & F; $30 \mathrm{yr} ; \mathrm{Fib}$ & $\begin{array}{l}\text { Episomal } \\
\text { vector }\end{array}$ & Morphology; IF & $\begin{array}{c}\text { Teratoma; EB } \\
\text { differentiation }\end{array}$ & $\mathrm{N} / \mathrm{D}$ & $100 \%(\mathrm{~N} / \mathrm{D})$ & $\mathrm{N} / \mathrm{D}$ & [226] \\
\hline MT-ND5 & MELAS & M-iPS (2 clones) & $\begin{array}{c}\text { m.13513G > A } \\
\text { p.(D393N) }\end{array}$ & $\mathrm{Fib}$ & Lentivirus & $\begin{array}{l}\text { Morphology; } \\
\text { RT-qPCR; IF }\end{array}$ & $\begin{array}{c}\text { EB } \\
\text { differentiation }\end{array}$ & $\begin{array}{l}\text { N/D; } \\
\text { Yes }\end{array}$ & $47 \%(50 \%)$ & $\mathrm{N} / \mathrm{D}$ & [69] \\
\hline MT-ND5 & $\begin{array}{c}\text { Leigh } \\
\text { syndrome }\end{array}$ & $\begin{array}{c}\text { iPSC (13513G/A) } \\
\text { ( } 5 \text { clones })\end{array}$ & $\begin{array}{l}\text { m.13513G > } \\
\text { Ap.(D393N) }\end{array}$ & Fib & Sendai virus & Morphology; IF & Teratoma & $\begin{array}{l}\text { G-banding; } \\
\text { Yes }\end{array}$ & $84 \%(32-100 \%)$ & Yes & [65] \\
\hline MT-ND5 & $\begin{array}{c}\text { Leigh } \\
\text { syndrome }\end{array}$ & LND554SV.3 & $\begin{array}{c}\text { m.13513G > A } \\
\text { p.(D393N) }\end{array}$ & M; Fib & Sendai virus & $\begin{array}{l}\text { Morphology; AP; } \\
\text { qPCR; IF; } \\
\text { hypomethylation }\end{array}$ & $\begin{array}{c}E B \\
\text { differentiation }\end{array}$ & $\begin{array}{l}\text { G-banding; } \\
\text { Yes }\end{array}$ & $55 \%(32 \%)$ & $\mathrm{N} / \mathrm{D}$ & [228] \\
\hline MT-ND5 & MELAS & $\begin{array}{l}\text { MELAS-iPSC } \\
\text { A01 (2 clones) }\end{array}$ & $\begin{array}{c}\text { m.13513G > A } \\
\text { p.(D393N) }\end{array}$ & M; 16 yr; Fib & $\begin{array}{l}\text { Episomal } \\
\text { vectors }\end{array}$ & $\begin{array}{l}\text { Morphology; } \\
\text { RT-PCR; IF }\end{array}$ & $\begin{array}{c}\text { EB } \\
\text { differentiation }\end{array}$ & $\begin{array}{l}\text { G-banding; } \\
\text { N/D }\end{array}$ & $20 \%(>60 \%)$ & Yes & [81] \\
\hline MT-RNR1 & SNHL & IBMSi004-A & $\mathrm{m} .1555 \mathrm{~A}>\mathrm{G}$ & $\begin{array}{l}\text { F; } 39 \text { yr; } \\
\text { PBMC }\end{array}$ & Sendai virus & RT-PCR; IF; FACS; & $\begin{array}{c}\text { Teratoma; EB } \\
\text { differentiation }\end{array}$ & $\begin{array}{l}\text { G-banding; } \\
\text { Yes }\end{array}$ & $\mathrm{N} / \mathrm{D}(84.7 \%)$ & Yes & [229] \\
\hline$M T-R N R 2^{e}$ & $\mathrm{HCM}$ & HCM-iPSC & $\mathrm{m} .2336 \mathrm{~T}>\mathrm{C}^{\mathrm{e}}$ & Urine cells & Retrovirus & $\begin{array}{c}\text { AP; qPCR; IF; } \\
\text { hypomethylation }\end{array}$ & $\begin{array}{c}\text { Teratoma; EB } \\
\text { differentiation }\end{array}$ & $\begin{array}{l}\text { G-banding; } \\
\text { N/D }\end{array}$ & $100 \%(\mathrm{~N} / \mathrm{D})$ & Yes & [230] \\
\hline$M T-T K$ & MERRF & M1-iPSC & $\mathrm{m} .8344 \mathrm{~A}>\mathrm{G}$ & F; 15 yr; Fib & Retrovirus & $\begin{array}{l}\text { Morphology; AP; } \\
\text { RT-PCR; IF }\end{array}$ & $\begin{array}{l}\text { Teratoma; EB } \\
\text { differentiation }\end{array}$ & $\mathrm{N} / \mathrm{D}$ & $90 \%(70 \%)$ & $\mathrm{N} / \mathrm{D}$ & [231] \\
\hline MT-TK & MERRF & M2-iPSC & $\mathrm{m} .8344 \mathrm{~A}>\mathrm{G}$ & F; 13 yr; Fib & Retrovirus & $\begin{array}{l}\text { Morphology; AP; } \\
\text { RT-PCR; IF }\end{array}$ & $\begin{array}{l}\text { Teratoma; EB } \\
\text { differentiation }\end{array}$ & $\mathrm{N} / \mathrm{D}$ & $60 \%(60 \%)$ & $\mathrm{N} / \mathrm{D}$ & [231] \\
\hline MT-TK & MERRF & $\begin{array}{l}\text { TVGH-iPSC- } \\
\text { MRF-M }^{\text {High }}\end{array}$ & m. $8344 \mathrm{~A}>\mathrm{G}$ & F; 15 yr; Fib & Retrovirus & RT-PCR; IF & $\begin{array}{l}\text { Teratoma; EB } \\
\text { differentiation }\end{array}$ & $\begin{array}{c}\text { G-banding; } \\
\text { Yes }\end{array}$ & $\mathrm{N} / \mathrm{D}(76 \%)$ & Yes & [232] \\
\hline MT-TL1 & MIDD & $\begin{array}{c}\text { Mt1 } \\
\text { (2 clones) }\end{array}$ & m.3243A > G & $\mathrm{M} ; 38 \mathrm{yr} ; \mathrm{Fib}$ & Retrovirus & $\begin{array}{c}\text { Morphology; AP; } \\
\text { IF; } \\
\text { hypomethylation }\end{array}$ & $\begin{array}{c}\text { Teratoma; EB } \\
\text { differentiation }\end{array}$ & $\begin{array}{l}\text { G-banding; } \\
\text { Yes }\end{array}$ & $18 \%(51 \%$ and $87 \%)$ & $\mathrm{N} / \mathrm{D}$ & [233] \\
\hline MT-TL1 & $\begin{array}{l}\text { MIDD and } \\
\text { MELAS }\end{array}$ & $\begin{array}{c}\text { Mt2 } \\
\text { (4 clones) }\end{array}$ & m.3243A > G & F; 46 yr; Fib & Retrovirus & $\begin{array}{c}\text { Morphology; AP; } \\
\text { IF; } \\
\text { hypomethylation }\end{array}$ & $\begin{array}{c}\text { Teratoma; EB } \\
\text { differentiation }\end{array}$ & $\begin{array}{c}\text { G-banding; } \\
\text { Yes }\end{array}$ & $24 \%(69-83 \%)$ & $\mathrm{N} / \mathrm{D}$ & [233] \\
\hline
\end{tabular}


Table A2. Cont.

\begin{tabular}{|c|c|c|c|c|c|c|c|c|c|c|c|}
\hline Gene(s) & Disease & Cell Line ID & Mutation & $\begin{array}{l}\text { Cell Line } \\
\text { Origin a }^{2}\end{array}$ & Reprogramming & Pluripotency & $\begin{array}{l}\text { Trilineage } \\
\text { Potential }\end{array}$ & $\begin{array}{c}\text { Karyotype; } \\
\text { Lineage } \\
\text { Validation }{ }^{b}\end{array}$ & $\begin{array}{c}\text { Heteroplasmy } \\
\text { Before (After) } \\
\text { Reprogramming }{ }^{\mathrm{c}}\end{array}$ & $\begin{array}{l}\text { Mycoplasma } \\
\text { Check }\end{array}$ & Ref. \\
\hline MT-TL1 & MIDD & $\begin{array}{c}\text { MH1, MH2 and } \\
\text { MH3 } \\
\text { (3 clones) }\end{array}$ & m.3243A > G & M; 39 yr; Fib & Retrovirus & $\begin{array}{l}\text { Morphology; IF; } \\
\text { RT-PCR }\end{array}$ & Teratoma & $\begin{array}{l}\text { G-banding; } \\
\text { Yes }\end{array}$ & $22 \%(>80 \%)$ & $\mathrm{N} / \mathrm{D}$ & [21] \\
\hline MT-TL1 & $\mathrm{CM}$ & P3-iPSC & m.3243A > G & F; 55 yr; Fib & Retrovirus & $\mathrm{N} / \mathrm{D}$ & $\mathrm{N} / \mathrm{D}$ & $\begin{array}{l}\text { N/D; } \\
\text { Yes }\end{array}$ & $35 \%(>80 \%)$ & $\mathrm{N} / \mathrm{D}$ & [21] \\
\hline MT-TL1 & MELAS & $\begin{array}{l}\text { MELAS-iPSC } \\
\text { (5 clones) }\end{array}$ & m.3243A $>$ G & Fib & Sendai virus & Morphology; IF & Teratoma & $\begin{array}{l}\text { G-banding; } \\
\text { Yes }\end{array}$ & $29 \%(33-100 \%)$ & Yes & [65] \\
\hline MT-TL1 & MELAS & $\begin{array}{l}\text { Patient \#1- } \\
\text { iPSCs }\end{array}$ & m. $3243 \mathrm{~A}>\mathrm{G}$ & $\mathrm{Fib}$ & $\begin{array}{l}\text { Episomal } \\
\text { plasmid }\end{array}$ & Morphology; IF & $\begin{array}{c}\text { EB } \\
\text { differentiation } \\
\end{array}$ & $\mathrm{N} / \mathrm{D}$ & 99\% (100\%) & $\mathrm{N} / \mathrm{D}$ & [90] \\
\hline MT-TL1 & MELAS & $\begin{array}{c}\text { Patient \#2- } \\
\text { iPSCs (3 clones) }\end{array}$ & m. $3243 \mathrm{~A}>\mathrm{G}$ & $\mathrm{Fib}$ & $\begin{array}{l}\text { Episomal } \\
\text { plasmid }\end{array}$ & Morphology; IF & $\begin{array}{c}\mathrm{EB} \\
\text { differentiation }\end{array}$ & $\mathrm{N} / \mathrm{D}$ & $\sim 69 \%$ (>70-100\%) & $\mathrm{N} / \mathrm{D}$ & [90] \\
\hline MT-TL1 & MELAS & $\begin{array}{c}\text { Patient \#3- } \\
\text { iPSCs ( } 3 \text { clones) }\end{array}$ & m. $3243 \mathrm{~A}>\mathrm{G}$ & $\mathrm{Fib}$ & $\begin{array}{l}\text { Episomal } \\
\text { plasmid }\end{array}$ & Morphology; IF & $\begin{array}{c}\text { EB } \\
\text { differentiation }\end{array}$ & $\mathrm{N} / \mathrm{D}$ & $\sim 55 \%(60-100 \%)$ & $\mathrm{N} / \mathrm{D}$ & [90] \\
\hline MT-TL1 & MELAS & $\begin{array}{l}\text { MELAS-iPSC } \\
\text { (16 clones) }\end{array}$ & m.3243A > G & Fib & Retrovirus & Morphology; IF & $\begin{array}{c}\text { Teratoma; EB } \\
\text { differentiation }\end{array}$ & $\begin{array}{l}\text { G-banding; } \\
\text { N/D }\end{array}$ & $78 \%(40-99 \%)$ & $\mathrm{N} / \mathrm{D}$ & [234] \\
\hline MT-TL1 & MELAS & $\begin{array}{c}\text { MitoA } \\
\text { hiPSCs } \\
\text { (7 clones) }\end{array}$ & m.3243A > G & F; 17 yr; Fib & Sendai virus & $\mathrm{N} / \mathrm{D}$ & N/D & $\begin{array}{l}\text { G-banding; } \\
\text { Yes }\end{array}$ & $17 \%(47-82 \%)$ & $\mathrm{N} / \mathrm{D}$ & [87] \\
\hline MT-TL1 & MELAS & $\begin{array}{c}\text { MitoB } \\
\text { hiPSCs } \\
\text { (5 clones) }\end{array}$ & $\mathrm{m} .3243 \mathrm{~A}>\mathrm{G}$ & F; 79 yr; Fib & Sendai virus & $\mathrm{N} / \mathrm{D}$ & $\mathrm{N} / \mathrm{D}$ & $\begin{array}{l}\text { G-banding; } \\
\text { Yes }\end{array}$ & $45 \%(38-81 \%)$ & N/D & [87] \\
\hline MT-TL1 & MELAS & $\begin{array}{c}\text { MitoC } \\
\text { hiPSCs } \\
\text { (9 clones) }\end{array}$ & m.3243A > G & M; 31 yr; Fib & Sendai virus & $\mathrm{N} / \mathrm{D}$ & $\mathrm{N} / \mathrm{D}$ & $\begin{array}{c}\text { G-banding; } \\
\text { Yes }\end{array}$ & $47 \%(38-83 \%)$ & $\mathrm{N} / \mathrm{D}$ & [87] \\
\hline MT-TL1 & MELAS & HH1 & m.3243A > G & $\mathrm{M} ; 42 \mathrm{yr} ; \mathrm{Fib}$ & Retrovirus & qPCR; IF & N/D & $\begin{array}{l}\text { G-banding; } \\
\text { N/D }\end{array}$ & $85 \%(71 \%)$ & $\mathrm{N} / \mathrm{D}$ & [97] \\
\hline MT-TL1 & MELAS & $\begin{array}{l}\text { P1 iPSCs } \\
\text { (2 clones) }\end{array}$ & m.3243A > G & F; 73 yr; Fib & Sendai virus & IF; FACS & $\begin{array}{l}\text { Spontaneous } \\
\text { monolayer } \\
\text { differentiation }\end{array}$ & $\begin{array}{l}\text { SNP-array; } \\
\text { Yes }\end{array}$ & $\begin{array}{c}\sim 70 \% \\
\left(50 \% \text { and } 70 \%{ }^{\mathrm{f}}\right)\end{array}$ & $\mathrm{N} / \mathrm{D}$ & [235] \\
\hline
\end{tabular}


Table A2. Cont.

\begin{tabular}{|c|c|c|c|c|c|c|c|c|c|c|c|}
\hline Gene(s) & Disease & Cell Line ID & Mutation & $\begin{array}{l}\text { Cell Line } \\
\text { Origin }^{\mathrm{a}}\end{array}$ & Reprogramming & Pluripotency & $\begin{array}{l}\text { Trilineage } \\
\text { Potential }\end{array}$ & $\begin{array}{c}\text { Karyotype; } \\
\text { Lineage } \\
\text { Validation }{ }^{b}\end{array}$ & $\begin{array}{c}\text { Heteroplasmy } \\
\text { Before (After) } \\
\text { Reprogramming }^{\mathrm{c}}\end{array}$ & $\begin{array}{l}\text { Mycoplasma } \\
\text { Check }\end{array}$ & Ref. \\
\hline MT-TW & MELAS & Patient ( 3 clones) & $\mathrm{m} .5541 \mathrm{C}>\mathrm{T}^{\mathrm{g}}$ & $\begin{array}{l}\mathrm{M} ;<15 \mathrm{yr} ; \\
\text { Myoblast }\end{array}$ & $\begin{array}{l}\text { Episomal } \\
\text { plasmid }\end{array}$ & Morphology; IF & $\begin{array}{c}\text { EB } \\
\text { differentiation }\end{array}$ & $\mathrm{N} / \mathrm{D}$ & $\sim 100 \%$ ( 100\%) & Yes & [46] \\
\hline $\begin{array}{c}\text { MT-ND4/5; } \\
\text { MT- } \\
\text { TL2/TS2/TH }\end{array}$ & $\begin{array}{l}\text { Pearson } \\
\text { syndrome }\end{array}$ & PS-iPS ( 3 clones) & $\begin{array}{l}\text { m.10949_13449del } \\
\text { (2501bp deletion) }\end{array}$ & F; 3 yr; Fib & Retrovirus & $\begin{array}{l}\text { Morphology; AP; } \\
\text { RT-PCR;IF }\end{array}$ & Teratoma & $\mathrm{N} / \mathrm{D}$ & $\sim 70 \%(55-70 \%)$ & $\mathrm{N} / \mathrm{D}$ & [45] \\
\hline $\begin{array}{c}\text { MT-ATP6; } \\
\text { MT-CO3; } \\
\text { MT- } \\
\text { ND3/4/4L/5/6; } \\
\text { MT-CYB; } \\
\text { MT- } \\
\text { TG/TR/TL2/ } \\
\text { TS2/TH/TE }\end{array}$ & $\begin{array}{l}\text { Pearson } \\
\text { syndrome }\end{array}$ & $\begin{array}{l}\text { GM04516PS- } \\
\text { iPSC }\end{array}$ & $\begin{array}{l}\text { m.8824_15854del } \\
\text { (7031bp deletion) }\end{array}$ & F; 5 yr; Fib & Retrovirus & $\mathrm{AP} ; \mathrm{IF}$ & Teratoma & $\mathrm{N} / \mathrm{D}$ & $6 \%(20 \%)$ & $\mathrm{N} / \mathrm{D}$ & [45] \\
\hline $\begin{array}{l}\text { MT-CO3; MT- } \\
\text { ND3/4/4L/5/6 }\end{array}$ & $\begin{array}{l}\text { Pearson } \\
\text { syndrome }\end{array}$ & FINCBi002-A & $\begin{array}{l}\text { m.9449_14550del } \\
\text { (5102bp deletion) }\end{array}$ & M; 5 mo; Fib & Sendai virus & $\begin{array}{l}\text { Morphology; AP; } \\
\text { RT-PCR; IF }\end{array}$ & $\begin{array}{c}\text { EB } \\
\text { differentiation }\end{array}$ & $\begin{array}{l}\text { Microarray; } \\
\text { Yes }\end{array}$ & $50 \%(80 \%)$ & Yes & [236] \\
\hline $\begin{array}{c}\text { MT-ATP6; } \\
\text { MT-CO3; MT- } \\
\text { ND3/4/4L/5 }\end{array}$ & $\begin{array}{l}\text { Pearson } \\
\text { syndrome }\end{array}$ & FINCBi003-A & $\begin{array}{l}\text { m.8469_13460del } \\
\text { (4992bp deletion) }\end{array}$ & M; 8 yr; Fib & Sendai virus & $\begin{array}{l}\text { Morphology; AP; } \\
\text { RT-PCR; IF }\end{array}$ & $\begin{array}{c}\text { EB } \\
\text { differentiation }\end{array}$ & $\begin{array}{l}\text { Microarray; } \\
\text { Yes }\end{array}$ & $10 \%(30 \%)$ & Yes & [236] \\
\hline
\end{tabular}

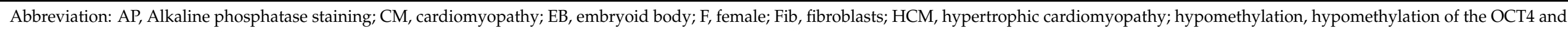

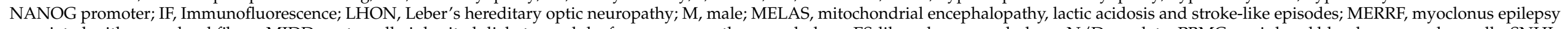

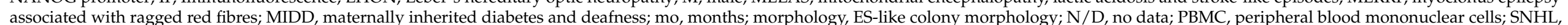

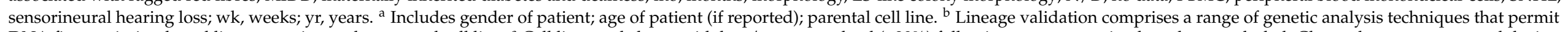

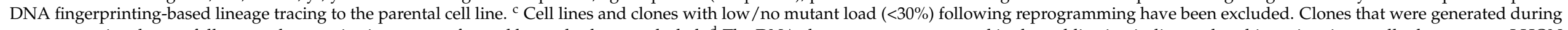

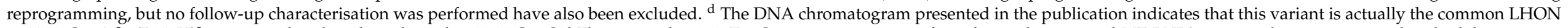

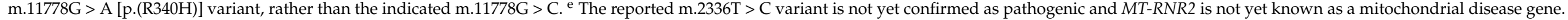

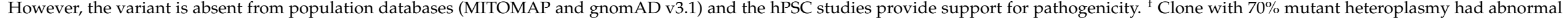

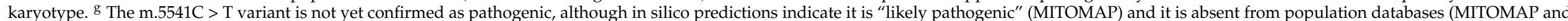
gnomAD v3.1). 
Table A3. Summary of functional defects of hPSC-derived clinically relevant cell types of nDNA associated mitochondrial diseases.

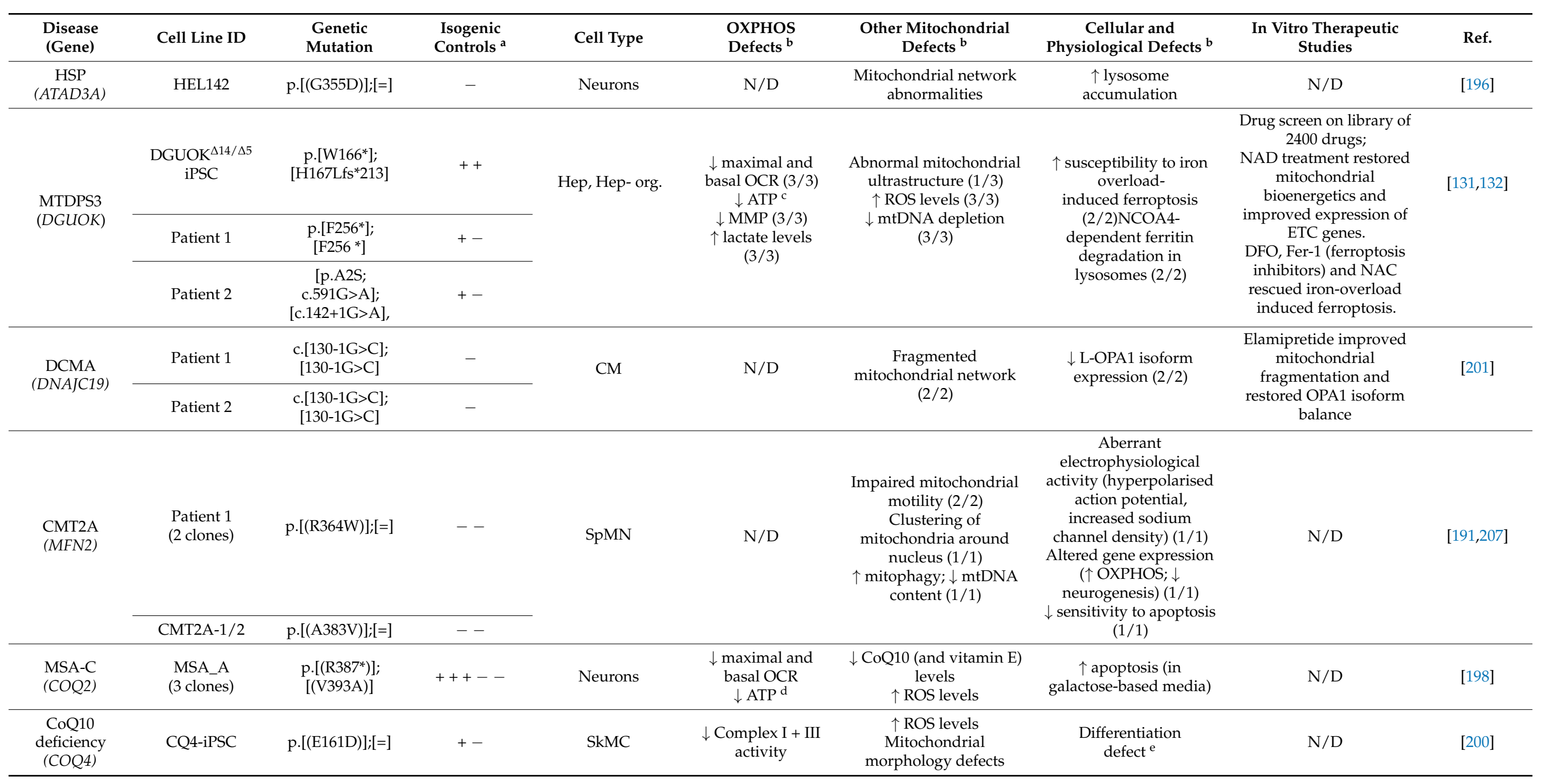


Table A3. Cont.

\begin{tabular}{|c|c|c|c|c|c|c|c|c|c|}
\hline $\begin{array}{l}\text { Disease } \\
\text { (Gene) }\end{array}$ & Cell Line ID & $\begin{array}{l}\text { Genetic } \\
\text { Mutation }\end{array}$ & $\begin{array}{l}\text { Isogenic } \\
\text { Controls }\end{array}$ & Cell Type & $\begin{array}{l}\text { OXPHOS } \\
\text { Defects }\end{array}$ & $\begin{array}{l}\text { Other Mitochondrial } \\
\text { Defects }{ }^{b}\end{array}$ & $\begin{array}{c}\text { Cellular and } \\
\text { Physiological Defects }\end{array}$ & $\begin{array}{c}\text { In Vitro Therapeutic } \\
\text { Studies }\end{array}$ & Ref. \\
\hline \multirow{7}{*}{$\begin{array}{l}\text { DOA and } \\
\text { Parkinson's } \\
\text { disease } \\
\text { (OPA1) }\end{array}$} & VO-iPSC & c. $[(2496+1 G>T)] ;[=]$ & - & \multirow{7}{*}{$\begin{array}{l}\text { NSC, NPC, RGC, } \\
\text { and/or Neurons }\end{array}$} & \multirow{7}{*}{$\begin{array}{c}\downarrow \text { maximal and } \\
\text { basal OCR }(4 / 5) \\
\downarrow \text { ATP c,d }(4 / 5) \\
\uparrow \text { glycolysis }(2 / 2) \\
\downarrow \text { MMP }(2 / 2) \\
\text { CI defect }(\downarrow \text { CI } \\
\text { subunit } \\
\text { expression, } \\
\text { activity and/or CI } \\
\text { related ATP } \\
\text { synthesis) }(4 / 4)\end{array}$} & \multirow{7}{*}{$\begin{array}{c}\text { Fragmented } \\
\text { mitochondrial network } \\
(4 / 5) \\
\uparrow \text { ROS levels (3/3) }\end{array}$} & \multirow{7}{*}{$\begin{array}{c}\text { Differentiation } \\
\text { defects }{ }^{\mathrm{e}} \text { and /or } \\
\text { increased } \\
\text { neurodegeneration over } \\
\text { prolonged culture }(7 / 7) \\
\text { Reduced mitochondrial } \\
\text { mass and loss of active } \\
\text { synaptic terminals } \\
\text { throughout prolonged } \\
\text { culture (microfluidic } \\
\text { neuronal Nigro-striatal } \\
\text { pathway model) }(1 / 1)\end{array}$} & \multirow{7}{*}{$\begin{array}{l}\text { NAC, Z-VAD (apoptosis } \\
\text { inhibitor), and Nec-1 } \\
\text { (necrosis inhibitor) } \\
\text { improved survival of } \\
\text { neurons derived from } \\
\text { NPCs. }\end{array}$} & \multirow{7}{*}{$\begin{array}{c}{[104,119,} \\
120,123,211]\end{array}$} \\
\hline & OL-iPSC & c. $[(2496+1 G>T)] ;[=]$ & - & & & & & & \\
\hline & $\begin{array}{l}\text { PD-OPA1 } \\
\text { G488R } \\
\text { (2 clones) }\end{array}$ & p.[G488R];[=] & +- & & & & & & \\
\hline & $\begin{array}{l}\text { PD-OPA1 } \\
\text { A495V \#72 }\end{array}$ & p. [A495V[;[=] & +- & & & & & & \\
\hline & $\begin{array}{l}\text { Opa1P } \\
\text { (2 clones) }\end{array}$ & $\begin{array}{c}\text { c. [(33- } \\
\text { 34ins9)];[=] }\end{array}$ & -- & & & & & & \\
\hline & $\begin{array}{c}\text { Opa1 } \\
\text { (2 clones) }\end{array}$ & $\begin{array}{c}\text { c.[(33- } \\
\text { 34ins9)];[=] }\end{array}$ & -- & & & & & & \\
\hline & OPA1+/- hESC & $\begin{array}{c}\mathrm{N} / \mathrm{D} \\
\text { (haploinsufficiency) }\end{array}$ & + & & & & & & \\
\hline $\begin{array}{l}\text { CMTX6 } \\
(P D K 3)\end{array}$ & iPSCCMTX6 & p.[(R158H)];[0] & + & SpMN & $\downarrow \mathrm{ATP}^{\mathrm{c}, \mathrm{d}}$ & $\begin{array}{c}\text { Fragmented } \\
\text { mitochondrial network } \\
\text { Mitochondrial } \\
\text { trafficking defect }\end{array}$ & $\begin{array}{c}\text { PDC E1 } \\
\text { hyperphosphorylation }\end{array}$ & $\begin{array}{l}\text { Treatment with the pan } \\
\text { PDK inhibitor DCA } \\
\text { reduced PDC E1 } \\
\text { hyperphosphorylation, } \\
\text { and improved } \\
\text { mitochondrial } \\
\text { fragmentation and } \\
\text { motility. }\end{array}$ & [216] \\
\hline $\begin{array}{l}\text { Leigh-like } \\
\text { syndrome } \\
(P M P C B)\end{array}$ & $\begin{array}{l}\text { DII- } 2 \text { iPSC } \\
\text { ( } 3 \text { clones) }\end{array}$ & p.[I422T];[I422T] & --- & NESC & $\mathrm{N} / \mathrm{D}$ & $\mathrm{N} / \mathrm{D}$ & $\begin{array}{l}\text { Inefficient processing } \\
\text { and accumulation of } \\
\text { intermediate Frataxin; } \\
\text { increased ISD complex } \\
\text { formation; increased } \\
\text { Fe-S cluster biogenesis }\end{array}$ & $\mathrm{N} / \mathrm{D}$ & [217] \\
\hline
\end{tabular}


Table A3. Cont.

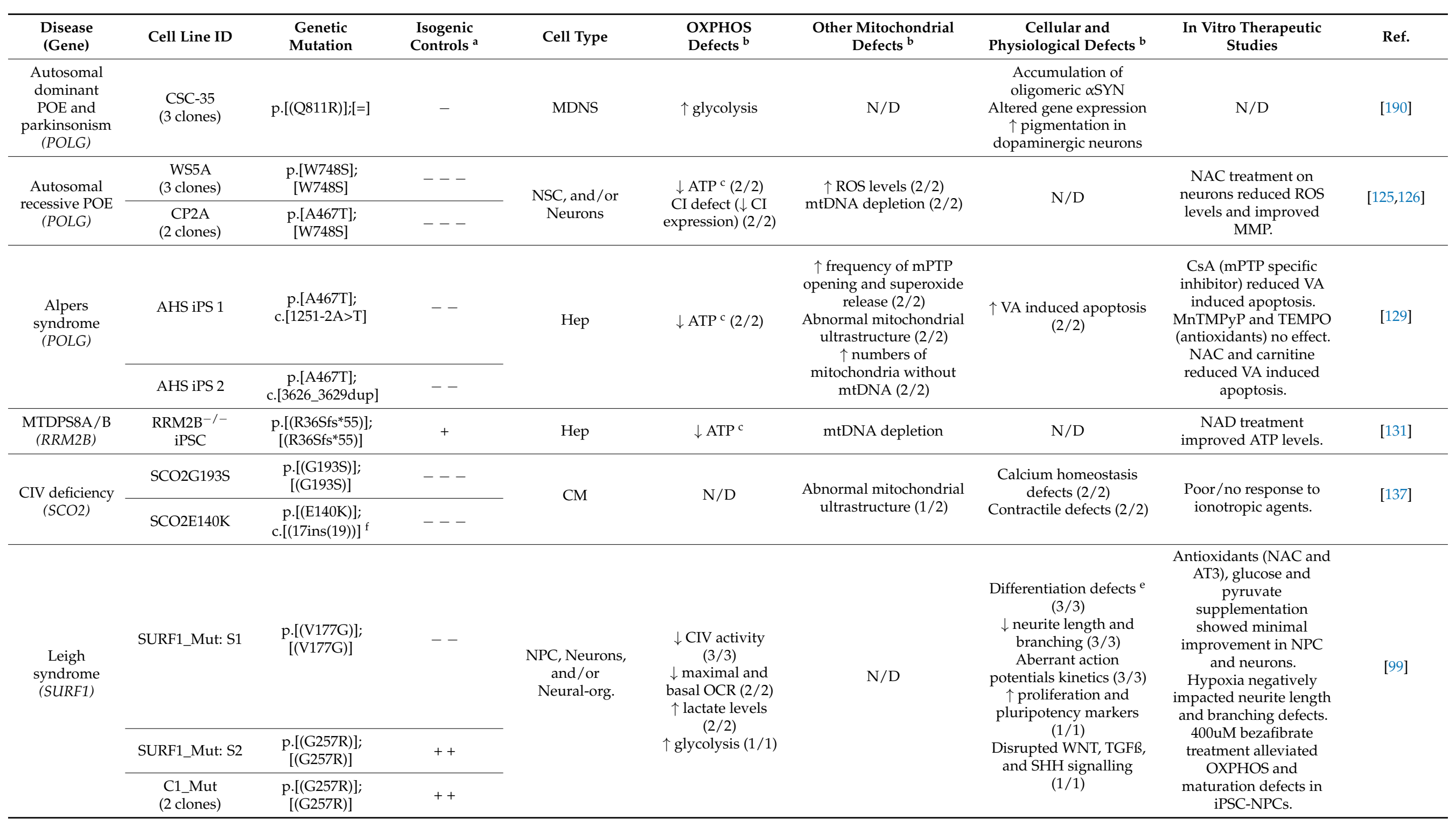


Table A3. Cont.

\begin{tabular}{|c|c|c|c|c|c|c|c|c|c|}
\hline $\begin{array}{l}\text { Disease } \\
\text { (Gene) }\end{array}$ & Cell Line ID & $\begin{array}{l}\text { Genetic } \\
\text { Mutation }\end{array}$ & $\begin{array}{l}\text { Isogenic } \\
\text { Controls }^{\text {a }}\end{array}$ & Cell Type & $\begin{array}{l}\text { OXPHOS } \\
\text { Defects }\end{array}$ & $\begin{array}{l}\text { Other Mitochondrial } \\
\text { Defects }{ }^{b}\end{array}$ & $\begin{array}{c}\text { Cellular and } \\
\text { Physiological Defects }\end{array}$ & $\begin{array}{c}\text { In Vitro Therapeutic } \\
\text { Studies }\end{array}$ & Ref. \\
\hline \multirow{4}{*}{$\begin{array}{c}\text { Barth } \\
\text { syndrome } \\
\text { (TAFAZZIN) }\end{array}$} & TAZ10 & p.[G197V];[0] & - & \multirow{4}{*}{ CM, Cardiac-org. } & \multirow{4}{*}{$\begin{array}{c}\uparrow \text { basal OCR } \\
(\text { compensatory } \\
\text { mechanism) (5/5) } \\
\downarrow \text { maximal OCR } \\
(5 / 5) \\
\downarrow \text { ATP }{ }^{\mathrm{c}} \text { in } \\
\text { galactose culture } \\
(4 / 4) \\
\downarrow \text { CII expression } \\
(1 / 1)\end{array}$} & \multirow{4}{*}{$\begin{array}{c}\uparrow \text { ROS levels }(2 / 2) \\
\text { Cardiolipin remodelling } \\
\text { defects }(4 / 4) \\
\text { Mitochondrial network } \\
\text { fragmentation }(1 / 1) \\
\text { Disrupted OXPHOS } \\
\text { supercomplex assembly } \\
(1 / 1)\end{array}$} & \multirow{4}{*}{$\begin{array}{c}\text { Disrupted sarcomeric } \\
\text { organization at single } \\
\text { cell level }(4 / 5) \\
\text { Contractile defects }(4 / 4) \\
\text { Metabolic alterations } \\
\text { and substrate utilization } \\
(1 / 1) \\
\text { Abnormal calcium } \\
\text { handling }(2 / 2) ; \\
\text { Increased diastolic } \\
\text { calcium leak through } \\
\text { RYR2 }(1 / 1) \\
\downarrow \text { HIF1 } \alpha \text { signalling } \\
\text { under hypoxic } \\
\text { conditions }(1 / 1)\end{array}$} & \multirow{4}{*}{$\begin{array}{c}\text { BL corrected cardiolipin } \\
\text { ratio. } \\
\text { Arg + Cys } \\
\text { supplementation } \\
\text { improved ATP levels. } \\
\text { LA improved MLCL:CL } \\
\text { ratio, increased ATP } \\
\text { levels, restored basal } \\
\text { OCR. LA and } \\
\text { MitoTEMPO reduced } \\
\text { ROS, and improved } \\
\text { sarcomere organisation } \\
\text { and contractile defects. }\end{array}$} & \multirow[t]{4}{*}{$\begin{array}{c}{[103,109,} \\
110,113,237]\end{array}$} \\
\hline & ВTH-H & p.[(D173Tfs*12)];[0] & +--- & & & & & & \\
\hline & 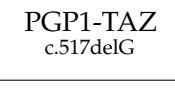 & p.[(D173Tfs*12)];[0] & + & & & & & & \\
\hline & $\underset{\text { c.517ins }}{\text { PGP1-TAZ }}$ & p.[(D173Efs)];[0] & + & & & & & & \\
\hline \multirow[b]{2}{*}{$\begin{array}{c}\mathrm{RP} \\
(\text { TRNT1) }\end{array}$} & P1 & $\begin{array}{l}\text { p.[(E43del)]; } \\
{[(\text { S418Vfs })]}\end{array}$ & $\begin{array}{c}----- \\
-\end{array}$ & \multirow[b]{2}{*}{ Retinal-org. } & \multirow[b]{2}{*}{$\mathrm{N} / \mathrm{D}$} & \multirow[b]{2}{*}{$\uparrow$ oxidative stress $(3 / 3)$} & \multirow{2}{*}{$\begin{array}{c}\uparrow \text { autophagy } \\
\text { (accumulation of LC3-II; } \\
\text { decreased LAMP1 } \\
\text { expression) }(3 / 3)\end{array}$} & \multirow[b]{2}{*}{$\mathrm{N} / \mathrm{D}$} & \multirow[b]{2}{*}{ [223] } \\
\hline & P2 & $\begin{array}{l}\text { p. }[(\mathrm{S} 418 \mathrm{Kfs})] ; \\
\text { c. }[609-26 \mathrm{~T}>\mathrm{C}]\end{array}$ & $\begin{array}{c}----- \\
- \\
\end{array}$ & & & & & & \\
\hline
\end{tabular}

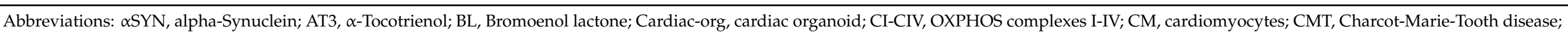

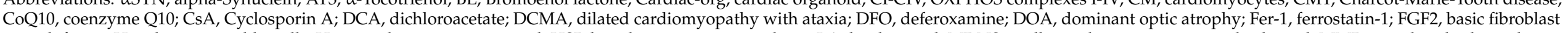

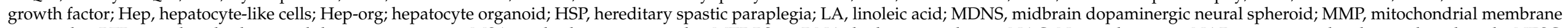

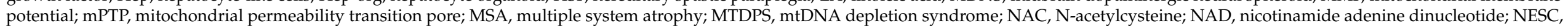

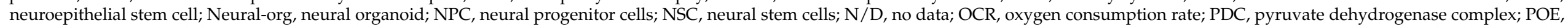

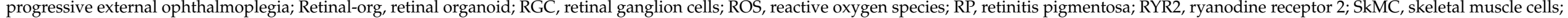

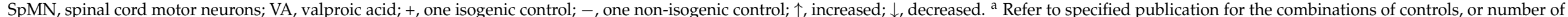

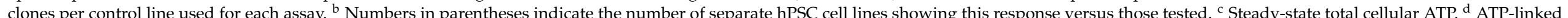

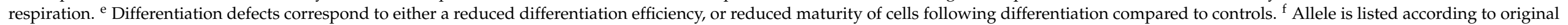
publication, due to ambiguity of the reported variant. 
Table A4. Functional defects of hPSC-derived clinically relevant cell types of mtDNA associated mitochondrial diseases.

\begin{tabular}{|c|c|c|c|c|c|c|c|c|c|}
\hline $\begin{array}{l}\text { Disease } \\
\text { (Gene) }\end{array}$ & Cell Line ID & $\begin{array}{c}\text { Genetic } \\
\text { Mutation }^{\text {a }}\end{array}$ & $\begin{array}{l}\text { Isogenic } \\
\text { Controls } b\end{array}$ & Cell Type & $\begin{array}{l}\text { OXPHOS } \\
\text { Defects }^{c}\end{array}$ & $\begin{array}{l}\text { Other Mitochondrial } \\
\text { Defects }^{c}\end{array}$ & $\begin{array}{c}\text { Cellular and } \\
\text { Physiological Defects }{ }^{c}\end{array}$ & $\begin{array}{c}\text { In Vitro Therapeutic } \\
\text { Studies }\end{array}$ & Ref. \\
\hline \multirow{4}{*}{$\begin{array}{l}\text { Leigh syndrome } \\
\text { (MT-ATP6) }\end{array}$} & TFA1 & $\begin{array}{c}\text { m.9185T > C } \\
(100 \% ; \text { p.L220P) }\end{array}$ & ----- & \multirow{4}{*}{ NPC, Neurons } & \multirow{4}{*}{$\begin{array}{c}\downarrow \operatorname{ATP} d, f(4 / 4) \\
\uparrow \operatorname{MMP}(4 / 4) \\
\downarrow \text { basal OCR }(1 / 1)\end{array}$} & \multirow{4}{*}{$\uparrow \operatorname{ROS}(1 / 1)$} & \multirow{4}{*}{$\begin{array}{c}\text { Calcium homeostasis } \\
\text { defect }(\downarrow \\
\text { calcium-induced } \\
\text { calcium release; ( } \downarrow \\
\text { mitochondrial calcium } \\
\text { release) }(3 / 3) \\
\uparrow \text { neurodegeneration } \\
(1 / 1)\end{array}$} & \multirow{4}{*}{$\begin{array}{l}\text { Tested } 130 \text { FDA approved } \\
\text { drugs; Avanafil (PDE5 } \\
\text { inhibitor) partially rescued } \\
\text { calcium homeostasis } \\
\text { defect in NPCs and } \\
\text { neuronsRapamycin } \\
\text { treatment improved ATP } \\
\text { production, decreased } \\
\text { aberrant AMPK activation, } \\
\text { and decreased glutamate } \\
\text { induced toxicity }\end{array}$} & \multirow{4}{*}[98,136]{} \\
\hline & TDA2.3 & $\begin{array}{c}\mathrm{m} .9185 \mathrm{~T}>\mathrm{C} \\
(100 \% ; \text { p.L220P) }\end{array}$ & ----- & & & & & & \\
\hline & TDA3.1 & $\begin{array}{c}\mathrm{m} .9185 \mathrm{~T}>\mathrm{C} \\
(100 \% ; \text { p.L220P })\end{array}$ & ----- & & & & & & \\
\hline & $\begin{array}{l}\text { GM13411(3 } \\
\text { clones) }\end{array}$ & $\begin{array}{c}\mathrm{m} .8993 \mathrm{~T}>\mathrm{G} \\
(100 \% ; \text { p.L156R })\end{array}$ & -- & & & & & & \\
\hline $\begin{array}{l}\text { Leigh syndrome } \\
\text { (MT-ND5) }\end{array}$ & LND554SV.3 & $\begin{array}{c}\text { m.13513G > A } \\
(19 \% ; p . D 393 N)\end{array}$ & - & $\begin{array}{c}\text { NSC, } \\
\text { Neurons }\end{array}$ & $\begin{array}{c}\downarrow \text { basal and } \\
\text { maximal OCR }\end{array}$ & $\mathrm{N} / \mathrm{D}$ & $\begin{array}{c}\uparrow \text { cell death } \\
\text { Calcium homeostasis } \\
\text { defect } \\
\text { ( } \downarrow \text { calcium buffering } \\
\text { capacity) }\end{array}$ & $\begin{array}{l}\text { Treatment with the } \\
\text { succinate prodrug NV241 } \\
\text { improved mitochondrial } \\
\text { respiration; however, } \\
\text { similar observations were } \\
\text { detected from DMSO } \\
\text { control }\end{array}$ & [102] \\
\hline $\begin{array}{l}\text { Leigh syndrome } \\
\quad(M T-A T P 6)\end{array}$ & Leigh iPSC & $\begin{array}{c}\mathrm{m} .8993 \mathrm{~T}>\mathrm{G} \\
\left(100 \%^{\mathrm{i}} ; \text { p.L156R }\right)\end{array}$ & + & SkMC & $\downarrow \mathrm{ATP}^{\mathrm{e}}$ & $\mathrm{N} / \mathrm{D}$ & $\mathrm{N} / \mathrm{D}$ & $\mathrm{N} / \mathrm{D}$ & {$[65]$} \\
\hline \multirow[t]{3}{*}{$\begin{array}{c}\text { LHON } \\
(\text { MT-ND4) }\end{array}$} & LHON-affected & $\begin{array}{c}\text { m.11778G > A } \\
(98.25 \% ; \text { p.R340H })\end{array}$ & -- & \multirow[t]{3}{*}{ RGC } & \multirow[t]{3}{*}{$\downarrow$ basal OCR $(2 / 2)$} & \multirow[t]{3}{*}{$\begin{array}{c}\uparrow \text { mtDNA copy } \\
\text { number } \\
\uparrow \operatorname{ROS}(2 / 2)\end{array}$} & \multirow{3}{*}{$\begin{array}{c}\text { Differentiation defect } \mathrm{g} \\
(2 / 3) \\
\text { Aberrant } \\
\text { electrophysiological } \\
\text { activity }(\downarrow \text { action } \\
\text { potential peaks) }(1 / 1) \\
\text { Defect in glutamate } \\
\text { uptake }(1 / 1) \\
\uparrow \text { apoptosis }(1 / 2) \\
\text { Changes in } \\
\text { mitochondrial transport; } \\
\text { reduced KIF5A } \\
\text { expression }(1 / 2) \\
\end{array}$} & \multirow[t]{3}{*}{$\begin{array}{l}\text { NAC reduced ROS levels } \\
\text { and apoptosis, and } \\
\text { restored KIF5A expression } \\
\text { and mitochondrial motility }\end{array}$} & \multirow[t]{3}{*}{$\begin{array}{c}{[101,165,} \\
166]\end{array}$} \\
\hline & $\begin{array}{c}\text { LHON- } \\
\text { unaffected }\end{array}$ & $\begin{array}{c}\text { m.11778G > A } \\
(98.42 \% ; \text { p.R340H })\end{array}$ & - & & & & & & \\
\hline & LHON-iPSC & $\begin{array}{c}\text { m.11778G > A } \\
(\mathrm{N} / \mathrm{D} ; \mathrm{p} . \mathrm{R} 340 \mathrm{H})\end{array}$ & - & & & & & & \\
\hline $\begin{array}{c}\text { LHON } \\
\text { (MT-ND1 and } \\
\text { MT-ND6) }\end{array}$ & $\begin{array}{l}\text { LHON Q1-4 } \\
\text { (3 clones) }\end{array}$ & $\begin{array}{c}\text { m.4160T >C } \\
\text { (p.L285P)/ } \\
\text { m.14484T >C } \\
\text { (p.M64V) }\left(100 \%{ }^{\mathrm{i}}\right)\end{array}$ & +- & RGC & & $\uparrow \operatorname{ROS}$ & $\uparrow$ apoptosis & $\mathrm{N} / \mathrm{D}$ & {$[64]$} \\
\hline
\end{tabular}


Table A4. Cont.

\begin{tabular}{|c|c|c|c|c|c|c|c|c|c|}
\hline $\begin{array}{l}\text { Disease } \\
\text { (Gene) }\end{array}$ & Cell Line ID & $\begin{array}{c}\text { Genetic } \\
\text { Mutation }^{\text {a }}\end{array}$ & $\begin{array}{c}\text { Isogenic } \\
\text { Controls }\end{array}$ & Cell Type & $\begin{array}{l}\text { OXPHOS } \\
\text { Defects }^{c}\end{array}$ & $\begin{array}{l}\text { Other Mitochondrial } \\
\text { Defects }^{c}\end{array}$ & $\begin{array}{c}\text { Cellular and } \\
\text { Physiological Defects }{ }^{c}\end{array}$ & $\begin{array}{c}\text { In Vitro Therapeutic } \\
\text { Studies }\end{array}$ & Ref. \\
\hline $\begin{array}{c}\text { HCM } \\
(M T-R N R 2)^{\mathrm{h}}\end{array}$ & HCM-iPSC & $\begin{array}{l}\mathrm{m} \cdot 2336 \mathrm{~T}>\mathrm{C} \\
\quad(\mathrm{N} / \mathrm{D})\end{array}$ & --- & $\mathrm{CM}$ & $\downarrow \mathrm{MMP}$ & $\begin{array}{c}\text { Mitochondrial } \\
\text { ultrastructural defects } \\
\uparrow \text { mtDNA copy } \\
\text { number } \\
\downarrow \text { stability of } 16 \text { s } r R N A\end{array}$ & $\begin{array}{c}\text { Calcium homeostasis } \\
\text { defects } \\
\text { Aberrant } \\
\text { electrophysiological } \\
\text { activity }\end{array}$ & $\mathrm{N} / \mathrm{D}$ & [230] \\
\hline $\begin{array}{l}\text { MERRF } \\
\text { (MT-TK) }\end{array}$ & M1-iPSC & $\begin{array}{c}\text { m. } 8344 \mathrm{~A}>\mathrm{G} \\
(\geq 40 \%)\end{array}$ & + & $\mathrm{CM}, \mathrm{NPC}$ & $\begin{array}{c}\downarrow \text { basal and } \\
\text { maximal OCR } \\
(2 / 2) \\
\downarrow \operatorname{ATP}^{\mathrm{e}}(2 / 2)\end{array}$ & $\begin{array}{c}\uparrow \operatorname{ROS}(2 / 2) \\
\text { Mitochondrial } \\
\text { fragmenta- } \\
\text { tion/morphology } \\
\text { defects }(2 / 2)\end{array}$ & $\begin{array}{c}\uparrow \text { expression of } \\
\text { antioxidant genes } \\
\text { catalase and CuZnSOD } \\
(2 / 2)\end{array}$ & $\mathrm{N} / \mathrm{D}$ & [231] \\
\hline $\begin{array}{l}\text { MELAS } \\
\text { (MT-TL1) }\end{array}$ & $\begin{array}{l}\text { P1 iPSCs } \\
\left(2 \text { clones }^{j}\right)\end{array}$ & $\begin{array}{c}\mathrm{m} .3243 \mathrm{~A}>\mathrm{G} \\
(>55 \%)\end{array}$ & --- & RPE & N/D & $\begin{array}{c}\text { Features of } \\
\text { mitochondrial } \\
\text { fragmenta- } \\
\text { tion/morphology } \\
\text { defects }\end{array}$ & $\begin{array}{c}\text { Atypical spatial } \\
\text { distribution of RPE } \\
\text { Underdeveloped } \\
\text { microvilliAberrant } \\
\text { melanosome } \\
\text { morphology } \\
\downarrow \text { phagocytosis of POS } \\
\end{array}$ & $\mathrm{N} / \mathrm{D}$ & [235] \\
\hline $\begin{array}{l}\text { MELAS } \\
\text { (MT-TL1) }\end{array}$ & MiPSC5 & $\begin{array}{c}\mathrm{m} .3243 \mathrm{~A}>\mathrm{G} \\
\quad(\sim 80 \%)\end{array}$ & +- & EC & $\mathrm{N} / \mathrm{D}$ & $\begin{array}{c}\uparrow \text { mitochondrial } \\
\text { biogenesis } \\
\uparrow \text { ROS }\end{array}$ & $\begin{array}{c}\text { Differentiation defects } \mathrm{g} \\
\downarrow \text { cell migration and tube } \\
\text { formation } \\
\uparrow \text { apoptosis } \\
\uparrow \text { uptake and oxidation } \\
\text { of LDL } \\
\uparrow \text { expression of VCAM-1 } \\
\text { isoform b } \\
\uparrow \text { monocyte adhesion to } \\
\text { EC }\end{array}$ & $\begin{array}{l}\text { Edaravone (anti-oxidant), } \\
\text { CoQ10 and Vit C improved } \\
\text { endothelial tube formation } \\
\text { and reduced ROS levels. } \\
\text { Edaravone also reduced } \\
\text { basal inflammation }\end{array}$ & [48] \\
\hline
\end{tabular}


Table A4. Cont.

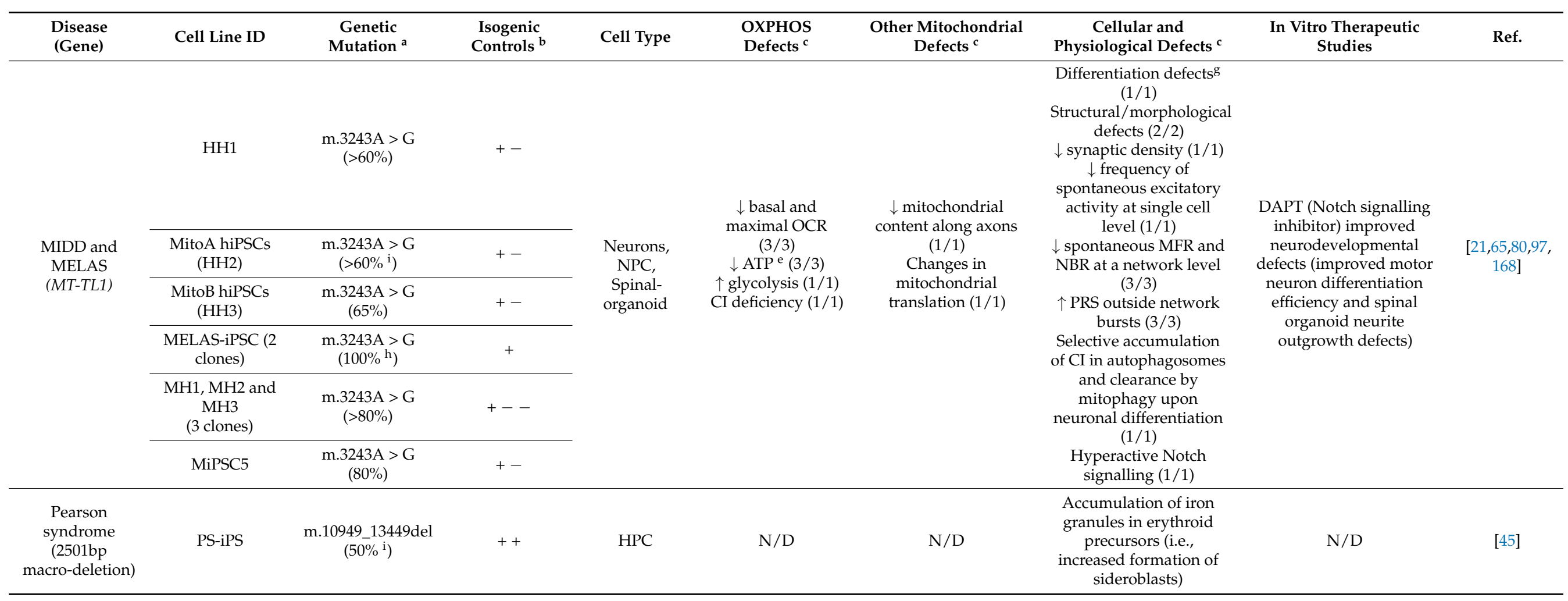

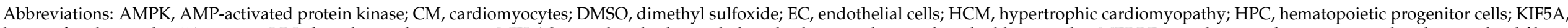

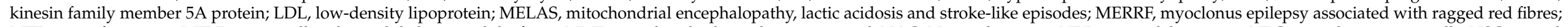

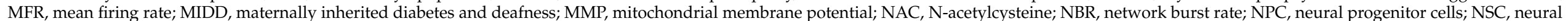

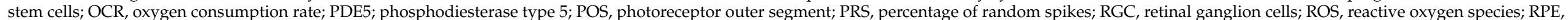

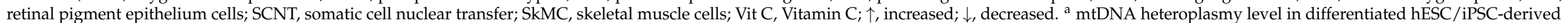

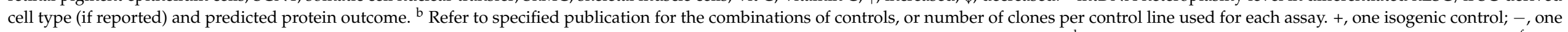

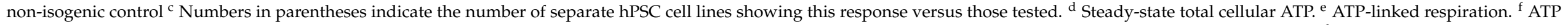

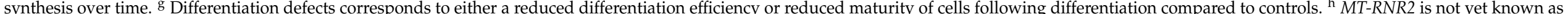

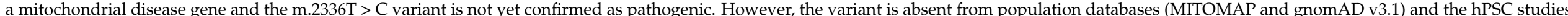
provide support for pathogenicity. ${ }^{i}$ mtDNA heteroplasmy level reported in undifferentiated hESC/iPSC only. ${ }^{j}$ One of the clones used in this study had an abnormal karyotype. 


\section{References}

1. McBride, H.M.; Neuspiel, M.; Wasiak, S. Mitochondria: More than just a powerhouse. Curr. Biol. 2006, 16, R551-R560. [CrossRef]

2. Krabbendam, I.E.; Honrath, B.; Culmsee, C.; Dolga, A.M. Mitochondrial $\mathrm{Ca}^{2+}$-activated $\mathrm{K}^{+}$channels and their role in cell life and death pathways. Cell Calcium 2018, 69, 101-111. [CrossRef] [PubMed]

3. Russell, O.M.; Gorman, G.S.; Lightowlers, R.N.; Turnbull, D.M. Mitochondrial diseases: Hope for the future. Cell 2020, 181, 168-188. [CrossRef]

4. Calvo, S.E.; Clauser, K.R.; Mootha, V.K. MitoCarta2.0: An updated inventory of mammalian mitochondrial proteins. Nucleic Acids Res. 2016, 44, D1251-D1257. [CrossRef] [PubMed]

5. Chinnery, P.F.; Hudson, G. Mitochondrial genetics. Br. Med. Bull. 2013, 106, 135-159. [CrossRef] [PubMed]

6. Rius, R.; Cowley, M.J.; Riley, L.; Puttick, C.; Thorburn, D.R.; Christodoulou, J. Biparental inheritance of mitochondrial DNA in humans is not a common phenomenon. Genet. Med. 2019, 21, 2823-2826. [CrossRef] [PubMed]

7. Shmookler Reis, R.J.; Goldstein, S. Mitochondrial DNA in mortal and immortal human cells. Genome number, integrity, and methylation. J. Biol. Chem. 1983, 258, 9078-9085. [CrossRef]

8. Wai, T.; Ao, A.; Zhang, X.; Cyr, D.; Dufort, D.; Shoubridge, E.A. The role of mitochondrial DNA copy number in mammalian fertility. Biol. Reprod. 2010, 83, 52-62. [CrossRef] [PubMed]

9. D’Erchia, A.M.; Atlante, A.; Gadaleta, G.; Pavesi, G.; Chiara, M.; De Virgilio, C.; Manzari, C.; Mastropasqua, F.; Prazzoli, G.M.; Picardi, E.; et al. Tissue-specific mtDNA abundance from exome data and its correlation with mitochondrial transcription, mass and respiratory activity. Mitochondrion 2015, 20, 13-21. [CrossRef]

10. Wachsmuth, M.; Hubner, A.; Li, M.; Madea, B.; Stoneking, M. Age-related and heteroplasmy-related variation in human mtDNA copy number. PLoS Genet. 2016, 12, e1005939. [CrossRef]

11. Wallace, D.C.; Chalkia, D. Mitochondrial DNA genetics and the heteroplasmy conundrum in evolution and disease. Cold Spring Harb. Perspect. Biol. 2013, 5, a021220. [CrossRef] [PubMed]

12. Ryzhkova, A.I.; Sazonova, M.A.; Sinyov, V.V.; Galitsyna, E.V.; Chicheva, M.M.; Melnichenko, A.A.; Grechko, A.V.; Postnov, A.Y.; Orekhov, A.N.; Shkurat, T.P. Mitochondrial diseases caused by mtDNA mutations: A mini-review. Ther. Clin. Risk Manag. 2018, 14, 1933-1942. [CrossRef]

13. Floros, V.I.; Pyle, A.; Dietmann, S.; Wei, W.; Tang, W.C.W.; Irie, N.; Payne, B.; Capalbo, A.; Noli, L.; Coxhead, J.; et al. Segregation of mitochondrial DNA heteroplasmy through a developmental genetic bottleneck in human embryos. Nat. Cell Biol. 2018, 20, 144-151. [CrossRef] [PubMed]

14. Wonnapinij, P.; Chinnery, P.F.; Samuels, D.C. The distribution of mitochondrial DNA heteroplasmy due to random genetic drift. Am. J. Hum. Genet. 2008, 83, 582-593. [CrossRef] [PubMed]

15. Papa, S.; Martino, P.L.; Capitanio, G.; Gaballo, A.; De Rasmo, D.; Signorile, A.; Petruzzella, V. The Oxidative Phosphorylation System in Mammalian Mitochondria; Springer: Amsterdam, The Netherlands, 2012; pp. 3-37.

16. Hock, D.H.; Robinson, D.R.L.; Stroud, D.A. Blackout in the powerhouse: Clinical phenotypes associated with defects in the assembly of OXPHOS complexes and the mitoribosome. Biochem. J. 2020, 477, 4085-4132. [CrossRef]

17. Jackson, T.D.; Palmer, C.S.; Stojanovski, D. Mitochondrial diseases caused by dysfunctional mitochondrial protein import. Biochem. Soc. Trans. 2018, 46, 1225-1238. [CrossRef]

18. Pfanner, N.; Warscheid, B.; Wiedemann, N. Mitochondrial proteins: From biogenesis to functional networks. Nat. Rev. Mol. Cell Biol. 2019, 20, 267-284. [CrossRef]

19. Frazier, A.E.; Thorburn, D.R.; Compton, A.G. Mitochondrial energy generation disorders: Genes, mechanisms, and clues to pathology. J. Biol. Chem. 2019, 294, 5386-5395. [CrossRef]

20. Stenton, S.L.; Prokisch, H. Genetics of mitochondrial diseases: Identifying mutations to help diagnosis. EBioMedicine 2020, 56, 102784. [CrossRef]

21. Hamalainen, R.H.; Manninen, T.; Koivumaki, H.; Kislin, M.; Otonkoski, T.; Suomalainen, A. Tissue- and cell-type-specific manifestations of heteroplasmic mtDNA 3243A $>\mathrm{G}$ mutation in human induced pluripotent stem cell-derived disease model. Proc. Natl. Acad. Sci. USA 2013, 110, E3622-E3630. [CrossRef]

22. Komen, J.C.; Thorburn, D.R. Turn up the power-Pharmacological activation of mitochondrial biogenesis in mouse models. Br. J. Pharmacol. 2014, 171, 1818-1836. [CrossRef]

23. Quadalti, C.; Brunetti, D.; Lagutina, I.; Duchi, R.; Perota, A.; Lazzari, G.; Cerutti, R.; Di Meo, I.; Johnson, M.; Bottani, E.; et al. SURF1 knockout cloned pigs: Early onset of a severe lethal phenotype. Biochim. Biophys. Acta Mol. Basis Dis. 2018, 1864, $2131-2142$. [CrossRef]

24. Deepa, S.S.; Pharaoh, G.; Kinter, M.; Diaz, V.; Fok, W.C.; Riddle, K.; Pulliam, D.; Hill, S.; Fischer, K.E.; Soto, V.; et al. Lifelong reduction in complex IV induces tissue-specific metabolic effects but does not reduce lifespan or healthspan in mice. Aging Cell 2018, 17, e12769. [CrossRef]

25. Dell'agnello, C.; Leo, S.; Agostino, A.; Szabadkai, G.; Tiveron, C.; Zulian, A.; Prelle, A.; Roubertoux, P.; Rizzuto, R.; Zeviani, M. Increased longevity and refractoriness to $\mathrm{Ca}^{2+}$-dependent neurodegeneration in Surf1 knockout mice. Hum. Mol. Genet. 2007, 16, 431-444. [CrossRef] 
26. Ruzzenente, B.; Rotig, A.; Metodiev, M.D. Mouse models for mitochondrial diseases. Hum. Mol. Genet. 2016, 25, R115-R122. [CrossRef] [PubMed]

27. Pfeffer, G.; Majamaa, K.; Turnbull, D.M.; Thorburn, D.; Chinnery, P.F. Treatment for mitochondrial disorders. Cochrane Database Syst. Rev. 2012, CD004426. [CrossRef]

28. Liufu, T.; Wang, Z. Treatment for mitochondrial diseases. Rev. Neurosci. 2020, 32, 35-47. [CrossRef] [PubMed]

29. Parikh, S.; Goldstein, A.; Karaa, A.; Koenig, M.K.; Anselm, I.; Brunel-Guitton, C.; Christodoulou, J.; Cohen, B.H.; Dimmock, D.; Enns, G.M.; et al. Patient care standards for primary mitochondrial disease: A consensus statement from the Mitochondrial Medicine Society. Genet. Med. 2017, 19, 1380. [CrossRef] [PubMed]

30. Zakrzewski, W.; Dobrzynski, M.; Szymonowicz, M.; Rybak, Z. Stem cells: Past, present, and future. Stem Cell Res. Ther. 2019, 10, 68. [CrossRef]

31. Thomson, J.A.; Itskovitz-Eldor, J.; Shapiro, S.S.; Waknitz, M.A.; Swiergiel, J.J.; Marshall, V.S.; Jones, J.M. Embryonic stem cell lines derived from human blastocysts. Science 1998, 282, 1145-1147. [CrossRef]

32. Takahashi, K.; Yamanaka, S. Induction of pluripotent stem cells from mouse embryonic and adult fibroblast cultures by defined factors. Cell 2006, 126, 663-676. [CrossRef] [PubMed]

33. Narsinh, K.H.; Plews, J.; Wu, J.C. Comparison of human induced pluripotent and embryonic stem cells: Fraternal or identical twins? Mol. Ther. 2011, 19, 635-638. [CrossRef] [PubMed]

34. Jacobson, E.F.; Tzanakakis, E.S. Who will win: Induced pluripotent stem cells versus embryonic stem cells for beta cell replacement and diabetes disease modeling? Curr. Diab. Rep. 2018, 18, 133. [CrossRef] [PubMed]

35. KalantarMotamedi, Y.; Peymani, M.; Baharvand, H.; Nasr-Esfahani, M.H.; Bender, A. Systematic selection of small molecules to promote differentiation of embryonic stem cells and experimental validation for generating cardiomyocytes. Cell Death Discov. 2016, 2, 16007. [CrossRef] [PubMed]

36. Zhang, Y.; Pak, C.; Han, Y.; Ahlenius, H.; Zhang, Z.; Chanda, S.; Marro, S.; Patzke, C.; Acuna, C.; Covy, J.; et al. Rapid single-step induction of functional neurons from human pluripotent stem cells. Neuron 2013, 78, 785-798. [CrossRef]

37. Hofer, M.; Lutolf, M.P. Engineering organoids. Nat. Rev. Mater. 2021, 6, 402-420. [CrossRef]

38. Worsdorfer, P.; Takashi, I.; Asahina, I.; Sumita, Y.; Ergun, S. Do not keep it simple: Recent advances in the generation of complex organoids. J. Neural Transm. 2020, 127, 1569-1577. [CrossRef]

39. Lees, J.G.; Gardner, D.K.; Harvey, A.J. Pluripotent stem cell metabolism and mitochondria: Beyond ATP. Stem Cells Int. 2017, 2017, 2874283. [CrossRef]

40. O'Brien, L.C.; Keeney, P.M.; Bennett, J.P., Jr. Differentiation of human neural stem cells into motor neurons stimulates mitochondrial biogenesis and decreases glycolytic flux. Stem Cells Dev. 2015, 24, 1984-1994. [CrossRef]

41. Wanet, A.; Remacle, N.; Najar, M.; Sokal, E.; Arnould, T.; Najimi, M.; Renard, P. Mitochondrial remodeling in hepatic differentiation and dedifferentiation. Int. J. Biochem. Cell Biol. 2014, 54, 174-185. [CrossRef]

42. Theeuwes, W.F.; Gosker, H.R.; Langen, R.C.J.; Pansters, N.A.M.; Schols, A.; Remels, A.H.V. Inactivation of glycogen synthase kinase 3beta (GSK-3beta) enhances mitochondrial biogenesis during myogenesis. Biochim. Biophys. Acta Mol. Basis Dis. 2018, 1864, 2913-2926. [CrossRef] [PubMed]

43. Venkatesh, S.; Baljinnyam, E.; Tong, M.; Kashihara, T.; Yan, L.; Liu, T.; Li, H.; Xie, L.H.; Nakamura, M.; Oka, S.I.; et al. Proteomic analysis of mitochondrial biogenesis in cardiomyocytes differentiated from human induced pluripotent stem cells. Am. J. Physiol. Regul. Integr. Comp. Physiol. 2021, 320, R547-R562. [CrossRef] [PubMed]

44. Keller, A.; Dziedzicka, D.; Zambelli, F.; Markouli, C.; Sermon, K.; Spits, C.; Geens, M. Genetic and epigenetic factors which modulate differentiation propensity in human pluripotent stem cells. Hum. Reprod. Update 2018, 24, 162-175. [CrossRef]

45. Cherry, A.B.; Gagne, K.E.; McLoughlin, E.M.; Baccei, A.; Gorman, B.; Hartung, O.; Miller, J.D.; Zhang, J.; Zon, R.L.; Ince, T.A.; et al. Induced pluripotent stem cells with a mitochondrial DNA deletion. Stem Cells 2013, 31, 1287-1297. [CrossRef] [PubMed]

46. Hatakeyama, H.; Katayama, A.; Komaki, H.; Nishino, I.; Goto, Y. Molecular pathomechanisms and cell-type-specific disease phenotypes of MELAS caused by mutant mitochondrial tRNA(Trp). Acta Neuropathol. Commun. 2015, 3, 52. [CrossRef]

47. Wanet, A.; Arnould, T.; Najimi, M.; Renard, P. Connecting mitochondria, metabolism, and stem cell fate. Stem Cells Dev. 2015, 24, 1957-1971. [CrossRef]

48. Pek, N.M.Q.; Phua, Q.H.; Ho, B.X.; Pang, J.K.S.; Hor, J.H.; An, O.; Yang, H.H.; Yu, Y.; Fan, Y.; Ng, S.Y.; et al. Mitochondrial 3243A > $\mathrm{G}$ mutation confers pro-atherogenic and pro-inflammatory properties in MELAS iPS derived endothelial cells. Cell Death Dis. 2019, 10, 802. [CrossRef]

49. Adak, S.; Magdalene, D.; Deshmukh, S.; Das, D.; Jaganathan, B.G. A review on mesenchymal stem cells for treatment of retinal diseases. Stem Cell Rev. Rep. 2021. [CrossRef]

50. Lester Sequiera, G.; Srivastava, A.; Alagarsamy, K.N.; Rockman-Greenberg, C.; Dhingra, S. Generation and evaluation of isogenic iPSC as a source of cell replacement therapies in patients with Kearns Sayre syndrome. Cells 2021, 10, 568. [CrossRef]

51. Abdelalim, E.M. Modeling different types of diabetes using human pluripotent stem cells. Cell. Mol. Life Sci. 2021, 78, 2459-2483. [CrossRef]

52. Zhang, H.; Menzies, K.J.; Auwerx, J. The role of mitochondria in stem cell fate and aging. Development 2018, 145, dev143420. [CrossRef] [PubMed] 
53. Weykopf, B.; Haupt, S.; Jungverdorben, J.; Flitsch, L.J.; Hebisch, M.; Liu, G.H.; Suzuki, K.; Belmonte, J.C.I.; Peitz, M.; Blaess, S.; et al. Induced pluripotent stem cell-based modeling of mutant LRRK2-associated Parkinson's disease. Eur. J. Neurosci. 2019, 49, 561-589. [CrossRef] [PubMed]

54. Shaltouki, A.; Sivapatham, R.; Pei, Y.; Gerencser, A.A.; Momcilovic, O.; Rao, M.S.; Zeng, X. Mitochondrial alterations by PARKIN in dopaminergic neurons using PARK2 patient-specific and PARK2 knockout isogenic iPSC lines. Stem Cell Rep. 2015, 4, 847-859. [CrossRef] [PubMed]

55. Lopez-Marquez, A.; Alonso-Barroso, E.; Cerro-Tello, G.; Bravo-Alonso, I.; Arribas-Carreira, L.; Briso-Montiano, A.; Navarrete, R.; Perez-Cerda, C.; Ugarte, M.; Perez, B.; et al. Generation and characterization of a human iPSC line (UAMi004-A) from a patient with propionic acidemia due to defects in the PCCB gene. Stem Cell Res. 2019, 38, 101469. [CrossRef] [PubMed]

56. Alonso-Barroso, E.; Brasil, S.; Briso-Montiano, A.; Navarrete, R.; Perez-Cerda, C.; Ugarte, M.; Perez, B.; Desviat, L.R.; Richard, E. Generation and characterization of a human iPSC line from a patient with propionic acidemia due to defects in the PCCA gene. Stem Cell Res. 2017, 23, 173-177. [CrossRef]

57. Knottnerus, S.J.G.; Mengarelli, I.; Wust, R.C.I.; Baartscheer, A.; Bleeker, J.C.; Coronel, R.; Ferdinandusse, S.; Guan, K.; IJlst, L.; Li, W.; et al. Electrophysiological abnormalities in VLCAD deficient hiPSC-cardiomyocytes can be improved by lowering accumulation of fatty acid oxidation intermediates. Int. J. Mol. Sci. 2020, 21, 2589. [CrossRef]

58. Berry, B.J.; Smith, A.S.T.; Young, J.E.; Mack, D.L. Advances and current challenges associated with the use of human induced pluripotent stem cells in modeling neurodegenerative disease. Cells Tissues Organs 2018, 205, 331-349. [CrossRef]

59. Shi, Y.; Inoue, H.; Wu, J.C.; Yamanaka, S. Induced pluripotent stem cell technology: A decade of progress. Nat. Rev. Drug Discov. 2017, 16, 115-130. [CrossRef]

60. Martufi, M.; Good, R.B.; Rapiteanu, R.; Schmidt, T.; Patili, E.; Tvermosegaard, K.; New, M.; Nanthakumar, C.B.; Betts, J.; Blanchard, A.D.; et al. Single-step, high-efficiency CRISPR-Cas9 genome editing in primary human disease-derived fibroblasts. CRISPR J. 2019, 2, 31-40. [CrossRef]

61. Grobarczyk, B.; Franco, B.; Hanon, K.; Malgrange, B. Generation of isogenic human iPS cell line precisely corrected by genome editing using the CRISPR/Cas9 system. Stem Cell Rev. Rep. 2015, 11, 774-787. [CrossRef]

62. Howden, S.E.; Maufort, J.P.; Duffin, B.M.; Elefanty, A.G.; Stanley, E.G.; Thomson, J.A. Simultaneous reprogramming and gene correction of patient fibroblasts. Stem Cell Rep. 2015, 5, 1109-1118. [CrossRef] [PubMed]

63. Wilkins, H.M.; Carl, S.M.; Swerdlow, R.H. Cytoplasmic hybrid (cybrid) cell lines as a practical model for mitochondriopathies. Redox Biol. 2014, 2, 619-631. [CrossRef] [PubMed]

64. Wong, R.C.B.; Lim, S.Y.; Hung, S.S.C.; Jackson, S.; Khan, S.; Van Bergen, N.J.; De Smit, E.; Liang, H.H.; Kearns, L.S.; Clarke, L.; et al. Mitochondrial replacement in an iPSC model of Leber's hereditary optic neuropathy. Aging 2017, 9, 1341-1350. [CrossRef] [PubMed]

65. Ma, H.; Folmes, C.D.; Wu, J.; Morey, R.; Mora-Castilla, S.; Ocampo, A.; Ma, L.; Poulton, J.; Wang, X.; Ahmed, R.; et al. Metabolic rescue in pluripotent cells from patients with mtDNA disease. Nature 2015, 524, 234-238. [CrossRef]

66. Prigione, A.; Lichtner, B.; Kuhl, H.; Struys, E.A.; Wamelink, M.; Lehrach, H.; Ralser, M.; Timmermann, B.; Adjaye, J. Human induced pluripotent stem cells harbor homoplasmic and heteroplasmic mitochondrial DNA mutations while maintaining human embryonic stem cell-like metabolic reprogramming. Stem Cells 2011, 29, 1338-1348. [CrossRef]

67. Takahashi, K.; Okita, K.; Nakagawa, M.; Yamanaka, S. Induction of pluripotent stem cells from fibroblast cultures. Nat. Protoc. 2007, 2, 3081-3089. [CrossRef] [PubMed]

68. Al Abbar, A.; Ngai, S.C.; Nograles, N.; Alhaji, S.Y.; Abdullah, S. Induced pluripotent stem cells: Reprogramming platforms and applications in cell replacement therapy. Biores. Open Access 2020, 9, 121-136. [CrossRef]

69. Folmes, C.D.; Martinez-Fernandez, A.; Perales-Clemente, E.; Li, X.; McDonald, A.; Oglesbee, D.; Hrstka, S.C.; Perez-Terzic, C.; Terzic, A.; Nelson, T.J. Disease-causing mitochondrial heteroplasmy segregated within induced pluripotent stem cell clones derived from a patient with MELAS. Stem Cells 2013, 31, 1298-1308. [CrossRef]

70. Mikkelsen, T.S.; Hanna, J.; Zhang, X.; Ku, M.; Wernig, M.; Schorderet, P.; Bernstein, B.E.; Jaenisch, R.; Lander, E.S.; Meissner, A. Dissecting direct reprogramming through integrative genomic analysis. Nature 2008, 454, 49-55. [CrossRef]

71. Fusaki, N.; Ban, H.; Nishiyama, A.; Saeki, K.; Hasegawa, M. Efficient induction of transgene-free human pluripotent stem cells using a vector based on Sendai virus, an RNA virus that does not integrate into the host genome. Proc. Jpn. Acad. Ser. B Phys. Biol. Sci. 2009, 85, 348-362. [CrossRef]

72. Yu, J.; Hu, K.; Smuga-Otto, K.; Tian, S.; Stewart, R.; Slukvin, I.I.; Thomson, J.A. Human induced pluripotent stem cells free of vector and transgene sequences. Science 2009, 324, 797-801. [CrossRef]

73. Kogut, I.; McCarthy, S.M.; Pavlova, M.; Astling, D.P.; Chen, X.; Jakimenko, A.; Jones, K.L.; Getahun, A.; Cambier, J.C.; Pasmooij, A.M.G.; et al. High-efficiency RNA-based reprogramming of human primary fibroblasts. Nat. Commun. 2018, 9, 745. [CrossRef]

74. Wang, A.Y.L.; Loh, C.Y.Y. Episomal induced pluripotent stem cells: Functional and potential therapeutic applications. Cell Transplant. 2019, 28, 112S-131S. [CrossRef]

75. Yaffe, M.P.; Noggle, S.A.; Solomon, S.L. Raising the standards of stem cell line quality. Nat. Cell Biol. 2016, 18, 236-237. [CrossRef]

76. Valenti, M.T.; Serena, M.; Carbonare, L.D.; Zipeto, D. CRISPR/Cas system: An emerging technology in stem cell research. World J. Stem Cells 2019, 11, 937-956. [CrossRef] [PubMed]

77. Jinek, M.; Chylinski, K.; Fonfara, I.; Hauer, M.; Doudna, J.A.; Charpentier, E. A programmable dual-RNA-guided DNA endonuclease in adaptive bacterial immunity. Science 2012, 337, 816-821. [CrossRef] 
78. Gammage, P.A.; Moraes, C.T.; Minczuk, M. Mitochondrial genome engineering: The revolution may not be CRISPR-Ized. Trends Genet. 2018, 34, 101-110. [CrossRef] [PubMed]

79. Hashimoto, M.; Bacman, S.R.; Peralta, S.; Falk, M.J.; Chomyn, A.; Chan, D.C.; Williams, S.L.; Moraes, C.T. MitoTALEN: A general approach to reduce mutant $\mathrm{mtDNA}$ loads and restore oxidative phosphorylation function in mitochondrial diseases. Mol. Ther. 2015, 23, 1592-1599. [CrossRef]

80. Yang, Y.; Wu, H.; Kang, X.; Liang, Y.; Lan, T.; Li, T.; Tan, T.; Peng, J.; Zhang, Q.; An, G.; et al. Targeted elimination of mutant mitochondrial DNA in MELAS-iPSCs by mitoTALENs. Protein Cell 2018, 9, 283-297. [CrossRef] [PubMed]

81. Yahata, N.; Matsumoto, Y.; Omi, M.; Yamamoto, N.; Hata, R. TALEN-mediated shift of mitochondrial DNA heteroplasmy in MELAS-iPSCs with m.13513G>A mutation. Sci. Rep. 2017, 7, 15557. [CrossRef] [PubMed]

82. Bacman, S.R.; Williams, S.L.; Pinto, M.; Moraes, C.T. The use of mitochondria-targeted endonucleases to manipulate mtDNA. Methods Enzymol. 2014, 547, 373-397. [CrossRef] [PubMed]

83. Mok, B.Y.; de Moraes, M.H.; Zeng, J.; Bosch, D.E.; Kotrys, A.V.; Raguram, A.; Hsu, F.; Radey, M.C.; Peterson, S.B.; Mootha, V.K.; et al. A bacterial cytidine deaminase toxin enables CRISPR-free mitochondrial base editing. Nature 2020, 583, 631-637. [CrossRef] [PubMed]

84. Liu, X.; Li, C.; Zheng, K.; Zhao, X.; Xu, X.; Yang, A.; Yi, M.; Tao, H.; Xie, B.; Qiu, M.; et al. Chromosomal aberration arises during somatic reprogramming to pluripotent stem cells. Cell Div. 2020, 15, 12. [CrossRef] [PubMed]

85. Sullivan, S.; Stacey, G.N.; Akazawa, C.; Aoyama, N.; Baptista, R.; Bedford, P.; Bennaceur Griscelli, A.; Chandra, A.; Elwood, N.; Girard, M.; et al. Quality control guidelines for clinical-grade human induced pluripotent stem cell lines. Regen. Med. 2018, 13, 859-866. [CrossRef] [PubMed]

86. Popp, B.; Krumbiegel, M.; Grosch, J.; Sommer, A.; Uebe, S.; Kohl, Z.; Plotz, S.; Farrell, M.; Trautmann, U.; Kraus, C.; et al. Need for high-resolution genetic analysis in iPSC: Results and lessons from the ForIPS consortium. Sci. Rep. 2018, 8, 17201. [CrossRef]

87. Perales-Clemente, E.; Cook, A.N.; Evans, J.M.; Roellinger, S.; Secreto, F.; Emmanuele, V.; Oglesbee, D.; Mootha, V.K.; Hirano, M.; Schon, E.A.; et al. Natural underlying mtDNA heteroplasmy as a potential source of intra-person hiPSC variability. EMBO J. 2016, 35, 1979-1990. [CrossRef] [PubMed]

88. Yokota, M.; Hatakeyama, H.; Ono, Y.; Kanazawa, M.; Goto, Y.I. Mitochondrial respiratory dysfunction disturbs neuronal and cardiac lineage commitment of human iPSCs. Cell Death Dis. 2017, 8, e2551. [CrossRef]

89. Sercel, A.J.; Carlson, N.M.; Patananan, A.N.; Teitell, M.A. Mitochondrial DNA dynamics in reprogramming to pluripotency. Trends Cell Biol. 2021, 31, 311-323. [CrossRef]

90. Yokota, M.; Hatakeyama, H.; Okabe, S.; Ono, Y.; Goto, Y. Mitochondrial respiratory dysfunction caused by a heteroplasmic mitochondrial DNA mutation blocks cellular reprogramming. Hum. Mol. Genet. 2015, 24, 4698-4709. [CrossRef]

91. Kosanke, M.; Davenport, C.; Szepes, M.; Wiehlmann, L.; Kohrn, T.; Dorda, M.; Gruber, J.; Menge, K.; Sievert, M.; Melchert, A.; et al. iPSC culture expansion selects against putatively actionable mutations in the mitochondrial genome. bioRxiv 2020. [CrossRef]

92. Zambelli, F.; Mertens, J.; Dziedzicka, D.; Sterckx, J.; Markouli, C.; Keller, A.; Tropel, P.; Jung, L.; Viville, S.; Van de Velde, H.; et al. Random mutagenesis, clonal events, and embryonic or somatic origin determine the mtDNA variant type and load in human pluripotent stem cells. Stem Cell Rep. 2018, 11, 102-114. [CrossRef] [PubMed]

93. Russell, O.M.; Fruh, I.; Rai, P.K.; Marcellin, D.; Doll, T.; Reeve, A.; Germain, M.; Bastien, J.; Rygiel, K.A.; Cerino, R.; et al. Preferential amplification of a human mitochondrial DNA deletion in vitro and in vivo. Sci. Rep. 2018, 8, 1799. [CrossRef] [PubMed]

94. Zambelli, F.; Spits, C. A step forward in disease modelling for mitochondrial diseases. Stem Cell Investig. 2017, 4, 89. [CrossRef] [PubMed]

95. Kargaran, P.K.; Mosqueira, D.; Kozicz, T. Mitochondrial medicine: Genetic underpinnings and disease modeling using induced pluripotent stem cell technology. Front. Cardiovasc. Med. 2020, 7, 604581. [CrossRef] [PubMed]

96. Inak, G.; Lorenz, C.; Lisowski, P.; Zink, A.; Mlody, B.; Prigione, A. Concise review: Induced pluripotent stem cell-based drug discovery for mitochondrial disease. Stem Cells 2017, 35, 1655-1662. [CrossRef]

97. Klein Gunnewiek, T.M.; Van Hugte, E.J.H.; Frega, M.; Guardia, G.S.; Foreman, K.; Panneman, D.; Mossink, B.; Linda, K.; Keller, J.M.; Schubert, D.; et al. m.3243A > G-induced mitochondrial dysfunction impairs human neuronal development and reduces neuronal network activity and synchronicity. Cell Rep. 2020, 31, 107538. [CrossRef]

98. Lorenz, C.; Lesimple, P.; Bukowiecki, R.; Zink, A.; Inak, G.; Mlody, B.; Singh, M.; Semtner, M.; Mah, N.; Aure, K.; et al. Human iPSC-derived neural progenitors are an effective drug discovery model for neurological mtDNA disorders. Cell Stem Cell 2017, 20, 659-674. [CrossRef]

99. Inak, G.; Rybak-Wolf, A.; Lisowski, P.; Pentimalli, T.M.; Juttner, R.; Glazar, P.; Uppal, K.; Bottani, E.; Brunetti, D.; Secker, C.; et al. Defective metabolic programming impairs early neuronal morphogenesis in neural cultures and an organoid model of Leigh syndrome. Nat. Commun. 2021, 12, 1929. [CrossRef]

100. Bayzigitov, D.R.; Medvedev, S.P.; Dementyeva, E.V.; Bayramova, S.A.; Pokushalov, E.A.; Karaskov, A.M.; Zakian, S.M. Human induced pluripotent stem cell-derived cardiomyocytes afford new opportunities in inherited cardiovascular disease modeling. Cardiol. Res. Pract. 2016, 2016, 3582380. [CrossRef]

101. Yang, Y.P.; Nguyen, P.N.N.; Lin, T.C.; Yarmishyn, A.A.; Chen, W.S.; Hwang, D.K.; Chiou, G.Y.; Lin, T.W.; Chien, C.S.; Tsai, C.Y.; et al. Glutamate stimulation dysregulates AMPA receptors-induced signal transduction pathway in Leber's inherited optic neuropathy patient-specific hiPSC-derived retinal ganglion cells. Cells 2019, 8, 625. [CrossRef] 
102. Galera-Monge, T.; Zurita-Diaz, F.; Canals, I.; Hansen, M.G.; Rufian-Vazquez, L.; Ehinger, J.K.; Elmer, E.; Martin, M.A.; Garesse, R.; Ahlenius, H.; et al. Mitochondrial dysfunction and calcium dysregulation in leigh syndrome induced pluripotent stem cell derived neurons. Int. J. Mol. Sci. 2020, 21, 3191. [CrossRef]

103. Liu, X.; Wang, S.; Guo, X.; Li, Y.; Ogurlu, R.; Lu, F.; Prondzynski, M.; de la Serna Buzon, S.; Ma, Q.; Zhang, D.; et al. Increased reactive oxygen species-mediated $\mathrm{Ca}^{2+} /$ calmodulin-dependent protein kinase II activation contributes to calcium handling abnormalities and impaired contraction in Barth syndrome. Circulation 2021, 143, 1894-1911. [CrossRef] [PubMed]

104. Caglayan, S.; Hashim, A.; Cieslar-Pobuda, A.; Jensen, V.; Behringer, S.; Talug, B.; Chu, D.T.; Pecquet, C.; Rogne, M.; Brech, A.; et al. Optic atrophy 1 controls human neuronal development by preventing aberrant nuclear DNA methylation. iScience 2020, 23, 101154. [CrossRef]

105. Hang, C.; Song, Y.; Wu, F.; Dong, T.; Jiang, M.; Saleem, A.; Zhang, S.; Chang, Y.; Lu, W.; Cui, M. Generation of a homozygous COX6A2 knockout human embryonic stem cell line (WAe009-A-47) via an epiCRISPR/Cas9 system. Stem Cell Res. 2021, 50, 102152. [CrossRef]

106. Schreiber, A.M.; Misiorek, J.O.; Napierala, J.S.; Napierala, M. Progress in understanding Friedreich's ataxia using human induced pluripotent stem cells. Expert Opin. Orphan Drugs 2019, 7, 81-90. [CrossRef]

107. Paradies, G.; Paradies, V.; Ruggiero, F.M.; Petrosillo, G. Role of cardiolipin in mitochondrial function and dynamics in health and disease: Molecular and pharmacological aspects. Cells 2019, 8, 728. [CrossRef]

108. Musatov, A.; Sedlak, E. Role of cardiolipin in stability of integral membrane proteins. Biochimie 2017, 142, 102-111. [CrossRef] [PubMed]

109. Wang, G.; McCain, M.L.; Yang, L.; He, A.; Pasqualini, F.S.; Agarwal, A.; Yuan, H.; Jiang, D.; Zhang, D.; Zangi, L.; et al. Modeling the mitochondrial cardiomyopathy of Barth syndrome with induced pluripotent stem cell and heart-on-chip technologies. Nat. Med. 2014, 20, 616-623. [CrossRef] [PubMed]

110. Dudek, J.; Cheng, I.F.; Chowdhury, A.; Wozny, K.; Balleininger, M.; Reinhold, R.; Grunau, S.; Callegari, S.; Toischer, K.; Wanders, R.J.; et al. Cardiac-specific succinate dehydrogenase deficiency in Barth syndrome. EMBO Mol. Med. 2016, 8, 139-154. [CrossRef]

111. Van Werkhoven, M.A.; Thorburn, D.R.; Gedeon, A.K.; Pitt, J.J. Monolysocardiolipin in cultured fibroblasts is a sensitive and specific marker for Barth Syndrome. J. Lipid Res. 2006, 47, 2346-2351. [CrossRef] [PubMed]

112. Kolwicz, S.C., Jr.; Purohit, S.; Tian, R. Cardiac metabolism and its interactions with contraction, growth, and survival of cardiomyocytes. Circ. Res. 2013, 113, 603-616. [CrossRef]

113. Fatica, E.M.; DeLeonibus, G.A.; House, A.; Kodger, J.V.; Pearce, R.W.; Shah, R.R.; Levi, L.; Sandlers, Y. Barth syndrome: Exploring cardiac metabolism with induced pluripotent stem cell-derived cardiomyocytes. Metabolites 2019, 9, 306. [CrossRef]

114. Saric, A.; Andreau, K.; Armand, A.S.; Moller, I.M.; Petit, P.X. Barth syndrome: From mitochondrial dysfunctions associated with aberrant production of reactive oxygen species to pluripotent stem cell studies. Front. Genet. 2015, 6, 359. [CrossRef]

115. Reid Thompson, W.; Hornby, B.; Manuel, R.; Bradley, E.; Laux, J.; Carr, J.; Vernon, H.J. A phase 2/3 randomized clinical trial followed by an open-label extension to evaluate the effectiveness of elamipretide in Barth syndrome, a genetic disorder of mitochondrial cardiolipin metabolism. Genet. Med. 2021, 23, 471-478. [CrossRef] [PubMed]

116. Alexander, C.; Votruba, M.; Pesch, U.E.; Thiselton, D.L.; Mayer, S.; Moore, A.; Rodriguez, M.; Kellner, U.; Leo-Kottler, B.; Auburger, G.; et al. OPA1, encoding a dynamin-related GTPase, is mutated in autosomal dominant optic atrophy linked to chromosome 3q28. Nat. Genet. 2000, 26, 211-215. [CrossRef]

117. Delettre, C.; Lenaers, G.; Griffoin, J.M.; Gigarel, N.; Lorenzo, C.; Belenguer, P.; Pelloquin, L.; Grosgeorge, J.; Turc-Carel, C.; Perret, E.; et al. Nuclear gene OPA1, encoding a mitochondrial dynamin-related protein, is mutated in dominant optic atrophy. Nat. Genet. 2000, 26, 207-210. [CrossRef]

118. Kasahara, A.; Cipolat, S.; Chen, Y.; Dorn, G.W., 2nd; Scorrano, L. Mitochondrial fusion directs cardiomyocyte differentiation via calcineurin and Notch signaling. Science 2013, 342, 734-737. [CrossRef]

119. Iannielli, A.; Bido, S.; Folladori, L.; Segnali, A.; Cancellieri, C.; Maresca, A.; Massimino, L.; Rubio, A.; Morabito, G.; Caporali, L.; et al. Pharmacological inhibition of necroptosis protects from dopaminergic neuronal cell death in Parkinson's disease models. Cell Rep. 2018, 22, 2066-2079. [CrossRef]

120. Jonikas, M.; Madill, M.; Mathy, A.; Zekoll, T.; Zois, C.E.; Wigfield, S.; Kurzawa-Akanbi, M.; Browne, C.; Sims, D.; Chinnery, P.F.; et al. Stem cell modeling of mitochondrial parkinsonism reveals key functions of OPA1. Ann. Neurol. 2018, 83, 915-925. [CrossRef]

121. Lee, Y.J.; Jeong, S.Y.; Karbowski, M.; Smith, C.L.; Youle, R.J. Roles of the mammalian mitochondrial fission and fusion mediators Fis1, Drp1, and Opa1 in apoptosis. Mol. Biol. Cell 2004, 15, 5001-5011. [CrossRef]

122. Lynch, D.S.; Loh, S.H.Y.; Harley, J.; Noyce, A.J.; Martins, L.M.; Wood, N.W.; Houlden, H.; Plun-Favreau, H. Nonsyndromic Parkinson disease in a family with autosomal dominant optic atrophy due to OPA1 mutations. Neurol. Genet. 2017, 3, e188. [CrossRef]

123. Iannielli, A.; Ugolini, G.S.; Cordiglieri, C.; Bido, S.; Rubio, A.; Colasante, G.; Valtorta, M.; Cabassi, T.; Rasponi, M.; Broccoli, V. Reconstitution of the human nigro-striatal pathway on-a-chip reveals OPA1-dependent mitochondrial defects and loss of dopaminergic synapses. Cell Rep. 2019, 29, 4646-4656. [CrossRef] [PubMed]

124. Rahman, S.; Copeland, W.C. POLG-related disorders and their neurological manifestations. Nat. Rev. Neurol. $2019,15,40-52$. [CrossRef] [PubMed] 
125. Liang, K.X.; Kristiansen, C.K.; Mostafavi, S.; Vatne, G.H.; Zantingh, G.A.; Kianian, A.; Tzoulis, C.; Hoyland, L.E.; Ziegler, M.; Perez, R.M.; et al. Disease-specific phenotypes in iPSC-derived neural stem cells with POLG mutations. EMBO Mol. Med. 2020, 12, e12146. [CrossRef]

126. Liang, K.X.; Vatne, G.H.; Kristiansen, C.K.; Ievglevskyi, O.; Kondratskaya, E.; Glover, J.C.; Chen, A.; Sullivan, G.J.; Bindoff, L.A. $\mathrm{N}$-acetylcysteine amide ameliorates mitochondrial dysfunction and reduces oxidative stress in hiPSC-derived dopaminergic neurons with POLG mutation. Exp. Neurol. 2021, 337, 113536. [CrossRef]

127. Hernansanz-Agustin, P.; Enriquez, J.A. Generation of reactive oxygen species by mitochondria. Antioxidants 2021, $10,415$. [CrossRef] [PubMed]

128. Harding, B.N. Progressive neuronal degeneration of childhood with liver disease (Alpers-Huttenlocher syndrome): A personal review. J. Child Neurol. 1990, 5, 273-287. [CrossRef]

129. Li, S.; Guo, J.; Ying, Z.; Chen, S.; Yang, L.; Chen, K.; Long, Q.; Qin, D.; Pei, D.; Liu, X. Valproic acid-induced hepatotoxicity in Alpers syndrome is associated with mitochondrial permeability transition pore opening-dependent apoptotic sensitivity in an induced pluripotent stem cell model. Hepatology 2015, 61, 1730-1739. [CrossRef]

130. Mandel, H.; Szargel, R.; Labay, V.; Elpeleg, O.; Saada, A.; Shalata, A.; Anbinder, Y.; Berkowitz, D.; Hartman, C.; Barak, M. The deoxyguanosine kinase gene is mutated in individuals with depleted hepatocerebral mitochondrial DNA. Nat. Genet. 2001, 29, 337-341. [CrossRef]

131. Jing, R.; Corbett, J.L.; Cai, J.; Beeson, G.C.; Beeson, C.C.; Chan, S.S.; Dimmock, D.P.; Lazcares, L.; Geurts, A.M.; Lemasters, J.J.; et al. A screen using iPSC-derived hepatocytes reveals $\mathrm{NAD}^{+}$as a potential treatment for mtDNA depletion syndrome. Cell Rep. 2018, 25, 1469-1484. [CrossRef]

132. Guo, J.; Duan, L.; He, X.; Li, S.; Wu, Y.; Xiang, G.; Bao, F.; Yang, L.; Shi, H.; Gao, M.; et al. A combined model of human iPSC-derived liver organoids and hepatocytes reveals ferroptosis in DGUOK mutant mtDNA depletion syndrome. Adv. Sci. 2021, 8, 2004680. [CrossRef] [PubMed]

133. Nemoto, S.; Fergusson, M.M.; Finkel, T. SIRT1 functionally interacts with the metabolic regulator and transcriptional coactivator PGC-1\{alpha\}. J. Biol. Chem. 2005, 280, 16456-16460. [CrossRef] [PubMed]

134. Wu, Z.D.; Puigserver, P.; Andersson, U.; Zhang, C.Y.; Adelmant, G.; Mootha, V.; Troy, A.; Cinti, S.; Lowell, B.; Scarpulla, R.C.; et al. Mechanisms controlling mitochondrial biogenesis and respiration through the thermogenic coactivator PGC-1. Cell 1999, 98, 115-124. [CrossRef]

135. Lake, N.J.; Compton, A.G.; Rahman, S.; Thorburn, D.R. Leigh syndrome: One disorder, more than 75 monogenic causes. Ann. Neurol. 2016, 79, 190-203. [CrossRef] [PubMed]

136. Zheng, X.; Boyer, L.; Jin, M.; Kim, Y.; Fan, W.; Bardy, C.; Berggren, T.; Evans, R.M.; Gage, F.H.; Hunter, T. Alleviation of neuronal energy deficiency by mTOR inhibition as a treatment for mitochondria-related neurodegeneration. eLife 2016, 5, e13378. [CrossRef] [PubMed]

137. Hallas, T.; Eisen, B.; Shemer, Y.; Ben Jehuda, R.; Mekies, L.N.; Naor, S.; Schick, R.; Eliyahu, S.; Reiter, I.; Vlodavsky, E.; et al. Investigating the cardiac pathology of SCO2-mediated hypertrophic cardiomyopathy using patients induced pluripotent stem cell-derived cardiomyocytes. J. Cell. Mol. Med. 2018, 22, 913-925. [CrossRef]

138. Rahman, S.; Blok, R.B.; Dahl, H.H.; Danks, D.M.; Kirby, D.M.; Chow, C.W.; Christodoulou, J.; Thorburn, D.R. Leigh syndrome: Clinical features and biochemical and DNA abnormalities. Ann. Neurol. 1996, 39, 343-351. [CrossRef]

139. Sofou, K.; De Coo, I.F.; Isohanni, P.; Ostergaard, E.; Naess, K.; De Meirleir, L.; Tzoulis, C.; Uusimaa, J.; De Angst, I.B.; Lonnqvist, T.; et al. A multicenter study on Leigh syndrome: Disease course and predictors of survival. Orphanet J. Rare Dis. $2014,9,52$. [CrossRef]

140. Ma, Y.Y.; Wu, T.F.; Liu, Y.P.; Wang, Q.; Song, J.Q.; Li, X.Y.; Shi, X.Y.; Zhang, W.N.; Zhao, M.; Hu, L.Y.; et al. Genetic and biochemical findings in Chinese children with Leigh syndrome. J. Clin. Neurosci. 2013, 20, 1591-1594. [CrossRef]

141. Mick, D.U.; Dennerlein, S.; Wiese, H.; Reinhold, R.; Pacheu-Grau, D.; Lorenzi, I.; Sasarman, F.; Weraarpachai, W.; Shoubridge, E.A.; Warscheid, B.; et al. MITRAC links mitochondrial protein translocation to respiratory-chain assembly and translational regulation. Cell 2012, 151, 1528-1541. [CrossRef]

142. Kovarova, N.; Pecina, P.; Nuskova, H.; Vrbacky, M.; Zeviani, M.; Mracek, T.; Viscomi, C.; Houstek, J. Tissue- and species-specific differences in cytochrome c oxidase assembly induced by SURF1 defects. Biochim. Biophys. Acta 2016, 1862, 705-715. [CrossRef] [PubMed]

143. Zhu, Z.; Yao, J.; Johns, T.; Fu, K.; De Bie, I.; Macmillan, C.; Cuthbert, A.P.; Newbold, R.F.; Wang, J.; Chevrette, M.; et al. SURF1, encoding a factor involved in the biogenesis of cytochrome c oxidase, is mutated in Leigh syndrome. Nat. Genet. 1998, 20, 337-343. [CrossRef] [PubMed]

144. Sue, C.M.; Karadimas, C.; Checcarelli, N.; Tanji, K.; Papadopoulou, L.C.; Pallotti, F.; Guo, F.L.; Shanske, S.; Hirano, M.; De Vivo, D.C.; et al. Differential features of patients with mutations in two COX assembly genes, SURF-1 and SCO2. Ann. Neurol. 2000, 47, 589-595. [CrossRef]

145. Leary, S.C.; Kaufman, B.A.; Pellecchia, G.; Guercin, G.H.; Mattman, A.; Jaksch, M.; Shoubridge, E.A. Human SCO1 and SCO2 have independent, cooperative functions in copper delivery to cytochrome c oxidase. Hum. Mol. Genet. 2004, 13, 1839-1848. [CrossRef]

146. Joost, K.; Rodenburg, R.; Piirsoo, A.; van den Heuvel, B.; Zordania, R.; Ounap, K. A novel mutation in the SCO2 gene in a neonate with early-onset cardioencephalomyopathy. Pediatr. Neurol. 2010, 42, 227-230. [CrossRef] [PubMed] 
147. Szymanska-Debinska, T.; Karkucinska-Wieckowska, A.; Piekutowska-Abramczuk, D.; Jurkiewicz, E.; Iwanicka-Pronicka, K.; Rokicki, D.; Pronicki, M. Leigh disease due to SCO2 mutations revealed at extended autopsy. J. Clin. Pathol. 2015, 68, 397-399. [CrossRef]

148. Papadopoulou, L.C.; Sue, C.M.; Davidson, M.M.; Tanji, K.; Nishino, I.; Sadlock, J.E.; Krishna, S.; Walker, W.; Selby, J.; Glerum, D.M.; et al. Fatal infantile cardioencephalomyopathy with COX deficiency and mutations in SCO2, a COX assembly gene. Nat. Genet. 1999, 23, 333-337. [CrossRef]

149. Jaksch, M.; Ogilvie, I.; Yao, J.; Kortenhaus, G.; Bresser, H.G.; Gerbitz, K.D.; Shoubridge, E.A. Mutations in SCO2 are associated with a distinct form of hypertrophic cardiomyopathy and cytochrome c oxidase deficiency. Hum. Mol. Genet. 2000, 9, 795-801. [CrossRef]

150. Wedatilake, Y.; Brown, R.M.; McFarland, R.; Yaplito-Lee, J.; Morris, A.A.; Champion, M.; Jardine, P.E.; Clarke, A.; Thorburn, D.R.; Taylor, R.W.; et al. SURF1 deficiency: A multi-centre natural history study. Orphanet J. Rare Dis. 2013, 8, 96. [CrossRef]

151. Benit, P.; El-Khoury, R.; Schiff, M.; Sainsard-Chanet, A.; Rustin, P. Genetic background influences mitochondrial function: Modeling mitochondrial disease for therapeutic development. Trends Mol. Med. 2010, 16, 210-217. [CrossRef]

152. Jain, I.H.; Zazzeron, L.; Goli, R.; Alexa, K.; Schatzman-Bone, S.; Dhillon, H.; Goldberger, O.; Peng, J.; Shalem, O.; Sanjana, N.E.; et al. Hypoxia as a therapy for mitochondrial disease. Science 2016, 352, 54-61. [CrossRef]

153. Ferrari, M.; Jain, I.H.; Goldberger, O.; Rezoagli, E.; Thoonen, R.; Cheng, K.H.; Sosnovik, D.E.; Scherrer-Crosbie, M.; Mootha, V.K.; Zapol, W.M. Hypoxia treatment reverses neurodegenerative disease in a mouse model of Leigh syndrome. Proc. Natl. Acad. Sci. USA 2017, 114, E4241-E4250. [CrossRef]

154. Jain, I.H.; Zazzeron, L.; Goldberger, O.; Marutani, E.; Wojtkiewicz, G.R.; Ast, T.; Wang, H.; Schleifer, G.; Stepanova, A.; Brepoels, K.; et al. Leigh syndrome mouse model can be rescued by interventions that normalize brain hyperoxia, but not HIF activation. Cell Metab. 2019, 30, 824-832. [CrossRef]

155. Augustyniak, J.; Lenart, J.; Gaj, P.; Kolanowska, M.; Jazdzewski, K.; Stepien, P.P.; Buzanska, L. Bezafibrate upregulates mitochondrial biogenesis and influence neural differentiation of human-induced pluripotent stem cells. Mol. Neurobiol. 2019, 56, 4346-4363. [CrossRef]

156. Steele, H.; Gomez-Duran, A.; Pyle, A.; Hopton, S.; Newman, J.; Stefanetti, R.J.; Charman, S.J.; Parikh, J.D.; He, L.; Viscomi, C.; et al. Metabolic effects of bezafibrate in mitochondrial disease. EMBO Mol. Med. 2020, 12, e11589. [CrossRef]

157. Montero, R.; Yubero, D.; Villarroya, J.; Henares, D.; Jou, C.; Rodriguez, M.A.; Ramos, F.; Nascimento, A.; Ortez, C.I.; Campistol, J.; et al. GDF-15 is elevated in children with mitochondrial diseases and is induced by mitochondrial dysfunction. PLoS ONE 2016, 11, e0148709. [CrossRef] [PubMed]

158. Lehtonen, J.M.; Forsstrom, S.; Bottani, E.; Viscomi, C.; Baris, O.R.; Isoniemi, H.; Hockerstedt, K.; Osterlund, P.; Hurme, M.; Jylhava, J.; et al. FGF21 is a biomarker for mitochondrial translation and mtDNA maintenance disorders. Neurology 2016, 87, 2290-2299. [CrossRef] [PubMed]

159. Ferrari, R.; Censi, S.; Mastrorilli, F.; Boraso, A. Prognostic benefits of heart rate reduction in cardiovascular disease. Eur. Heart J. Suppl. 2003, 5, G10-G14. [CrossRef]

160. Garbern, J.C.; Lee, R.T. Mitochondria and metabolic transitions in cardiomyocytes: Lessons from development for stem cellderived cardiomyocytes. Stem Cell Res. Ther. 2021, 12, 177. [CrossRef] [PubMed]

161. Cortes-Hernandez, P.; Vazquez-Memije, M.E.; Garcia, J.J. ATP6 homoplasmic mutations inhibit and destabilize the human F1F0-ATP synthase without preventing enzyme assembly and oligomerization. J. Biol. Chem. 2007, 282, 1051-1058. [CrossRef] [PubMed]

162. Manfredi, G.; Gupta, N.; Vazquez-Memije, M.E.; Sadlock, J.E.; Spinazzola, A.; De Vivo, D.C.; Schon, E.A. Oligomycin induces a decrease in the cellular content of a pathogenic mutation in the human mitochondrial ATPase 6 gene. J. Biol. Chem. 1999, 274, 9386-9391. [CrossRef]

163. Mattiazzi, M.; Vijayvergiya, C.; Gajewski, C.D.; DeVivo, D.C.; Lenaz, G.; Wiedmann, M.; Manfredi, G. The mtDNA T8993G (NARP) mutation results in an impairment of oxidative phosphorylation that can be improved by antioxidants. Hum. Mol. Genet. 2004, 13, 869-879. [CrossRef]

164. Trounce, I.; Neill, S.; Wallace, D.C. Cytoplasmic transfer of the mtDNA nt 8993 T->G (ATP6) point mutation associated with Leigh syndrome into mtDNA-less cells demonstrates cosegregation with a decrease in state III respiration and ADP/O ratio. Proc. Natl. Acad. Sci. USA 1994, 91, 8334-8338. [CrossRef]

165. Wu, Y.R.; Wang, A.G.; Chen, Y.T.; Yarmishyn, A.A.; Buddhakosai, W.; Yang, T.C.; Hwang, D.K.; Yang, Y.P.; Shen, C.N.; Lee, H.C.; et al. Bioactivity and gene expression profiles of hiPSC-generated retinal ganglion cells in MT-ND4 mutated Leber's hereditary optic neuropathy. Exp. Cell Res. 2018, 363, 299-309. [CrossRef] [PubMed]

166. Yang, T.C.; Yarmishyn, A.A.; Yang, Y.P.; Lu, P.C.; Chou, S.J.; Wang, M.L.; Lin, T.C.; Hwang, D.K.; Chou, Y.B.; Chen, S.J.; et al. Mitochondrial transport mediates survival of retinal ganglion cells in affected LHON patients. Hum. Mol. Genet. 2020, 29, 1454-1464. [CrossRef] [PubMed]

167. El-Hattab, A.W.; Adesina, A.M.; Jones, J.; Scaglia, F. MELAS syndrome: Clinical manifestations, pathogenesis, and treatment options. Mol. Genet. Metab. 2015, 116, 4-12. [CrossRef] [PubMed]

168. Winanto; Khong, Z.J.; Soh, B.S.; Fan, Y.; Ng, S.Y. Organoid cultures of MELAS neural cells reveal hyperactive Notch signaling that impacts neurodevelopment. Cell Death Dis. 2020, 11, 182. [CrossRef] [PubMed] 
169. Koga, Y.; Povalko, N.; Nishioka, J.; Katayama, K.; Kakimoto, N.; Matsuishi, T. MELAS and L-arginine therapy: Pathophysiology of stroke-like episodes. Ann. N. Y. Acad. Sci. 2010, 1201, 104-110. [CrossRef] [PubMed]

170. Rothstein, J.D. Edaravone: A new drug approved for ALS. Cell 2017, 171, 725. [CrossRef] [PubMed]

171. Grace, H.E.; Galdun, P., 3rd; Lesnefsky, E.J.; West, F.D.; Iyer, S. mRNA Reprogramming of T8993G Leigh's syndrome fibroblast cells to create induced pluripotent stem cell models for mitochondrial disorders. Stem Cells Dev. 2019, 28, 846-859. [CrossRef] [PubMed]

172. Grady, J.P.; Pickett, S.J.; Ng, Y.S.; Alston, C.L.; Blakely, E.L.; Hardy, S.A.; Feeney, C.L.; Bright, A.A.; Schaefer, A.M.; Gorman, G.S.; et al. mtDNA heteroplasmy level and copy number indicate disease burden in m.3243A $>\mathrm{G}$ mitochondrial disease. EMBO Mol. Med. 2018, 10, e8262. [CrossRef]

173. Karbassi, E.; Fenix, A.; Marchiano, S.; Muraoka, N.; Nakamura, K.; Yang, X.; Murry, C.E. Cardiomyocyte maturation: Advances in knowledge and implications for regenerative medicine. Nat. Rev. Cardiol. 2020, 17, 341-359. [CrossRef]

174. Terryn, J.; Tricot, T.; Gajjar, M.; Verfaillie, C. Recent advances in lineage differentiation from stem cells: Hurdles and opportunities? F1000Research 2018, 7, 220. [CrossRef]

175. Vieira, M.S.; Santos, A.K.; Vasconcellos, R.; Goulart, V.A.M.; Parreira, R.C.; Kihara, A.H.; Ulrich, H.; Resende, R.R. Neural stem cell differentiation into mature neurons: Mechanisms of regulation and biotechnological applications. Biotechnol. Adv. 2018, 36, 1946-1970. [CrossRef] [PubMed]

176. Kim, J.; Koo, B.K.; Knoblich, J.A. Human organoids: Model systems for human biology and medicine. Nat. Rev. Mol. Cell Biol. 2020, 21, 571-584. [CrossRef] [PubMed]

177. Patterson, M.; Chan, D.N.; Ha, I.; Case, D.; Cui, Y.; Van Handel, B.; Mikkola, H.K.; Lowry, W.E. Defining the nature of human pluripotent stem cell progeny. Cell Res. 2012, 22, 178-193. [CrossRef] [PubMed]

178. Ban, K.; Bae, S.; Yoon, Y.S. Current strategies and challenges for purification of cardiomyocytes derived from human pluripotent stem cells. Theranostics 2017, 7, 2067-2077. [CrossRef] [PubMed]

179. Velmurugan, B.K.; Bharathi Priya, L.; Poornima, P.; Lee, L.J.; Baskaran, R. Biomaterial aided differentiation and maturation of induced pluripotent stem cells. J. Cell. Physiol. 2019, 234, 8443-8454. [CrossRef]

180. Ahmed, R.E.; Anzai, T.; Chanthra, N.; Uosaki, H. A brief review of current maturation methods for human induced pluripotent stem cells-derived cardiomyocytes. Front. Cell Dev. Biol. 2020, 8, 178. [CrossRef] [PubMed]

181. Lam, D.; Enright, H.A.; Cadena, J.; Peters, S.K.G.; Sales, A.P.; Osburn, J.J.; Soscia, D.A.; Kulp, K.S.; Wheeler, E.K.; Fischer, N.O. Tissue-specific extracellular matrix accelerates the formation of neural networks and communities in a neuron-glia co-culture on a multi-electrode array. Sci. Rep. 2019, 9, 4159. [CrossRef] [PubMed]

182. Hedegaard, A.; Monzon-Sandoval, J.; Newey, S.E.; Whiteley, E.S.; Webber, C.; Akerman, C.J. Pro-maturational effects of human iPSC-derived cortical astrocytes upon iPSC-derived cortical neurons. Stem Cell Rep. 2020, 15, 38-51. [CrossRef]

183. Son, G.; Han, J. Roles of mitochondria in neuronal development. BMB Rep. 2018, 51, 549-556. [CrossRef]

184. Jensen, C.; Teng, Y. Is It Time to Start Transitioning From 2D to 3D Cell Culture? Front. Mol. Biosci. 2020, 7, 33. [CrossRef] [PubMed]

185. Kathuria, A.; Lopez-Lengowski, K.; Watmuff, B.; Karmacharya, R. Comparative transcriptomic analysis of cerebral organoids and cortical neuron cultures derived from human induced pluripotent stem cells. Stem Cells Dev. 2020, 29, 1370-1381. [CrossRef] [PubMed]

186. Bhaduri, A.; Andrews, M.G.; Kriegstein, A.R.; Nowakowski, T.J. Are organoids ready for prime time? Cell Stem Cell 2020, 27, 361-365. [CrossRef] [PubMed]

187. Doss, M.X.; Sachinidis, A. Current challenges of iPSC-based disease modeling and therapeutic implications. Cells $2019,8,403$. [CrossRef] [PubMed]

188. Elitt, M.S.; Barbar, L.; Tesar, P.J. Drug screening for human genetic diseases using iPSC models. Hum. Mol. Genet. 2018, 27, R89-R98. [CrossRef]

189. Khan, S.; Ince-Dunn, G.; Suomalainen, A.; Elo, L.L. Integrative omics approaches provide biological and clinical insights: Examples from mitochondrial diseases. J. Clin. Investig. 2020, 130, 20-28. [CrossRef]

190. Chumarina, M.; Russ, K.; Azevedo, C.; Heuer, A.; Pihl, M.; Collin, A.; Frostner, E.A.; Elmer, E.; Hyttel, P.; Cappelletti, G.; et al. Cellular alterations identified in pluripotent stem cell-derived midbrain spheroids generated from a female patient with progressive external ophthalmoplegia and parkinsonism who carries a novel variation (p.Q811R) in the POLG1 gene. Acta Neuropathol. Commun. 2019, 7, 208. [CrossRef]

191. Rizzo, F.; Ronchi, D.; Salani, S.; Nizzardo, M.; Fortunato, F.; Bordoni, A.; Stuppia, G.; Del Bo, R.; Piga, D.; Fato, R.; et al. Selective mitochondrial depletion, apoptosis resistance, and increased mitophagy in human charcot-marie-tooth $2 \mathrm{~A}$ motor neurons. Hum. Mol. Genet. 2016, 25, 4266-4281. [CrossRef] [PubMed]

192. Son, D.; Zheng, J.; Kim, I.Y.; You, S. Self-replicative mRNA-mediated generation of induced pluripotent stem cell line from a 1-year-old Leigh syndrome patient with mitochondrial DNA cytochrome b mutation. Stem Cell Res. 2021, 54, 102392. [CrossRef]

193. Van Helden, R.W.J.; Birket, M.J.; Freund, C.; Arendzen, C.H.; Mikkers, H.M.; Orlova, V.; de Coo, R.I.; Mummery, C.L.; Bellin, M. Generation of three human induced pluripotent stem cell lines, LUMCi024-A, LUMCi025-A, and LUMCi026-A, from two patients with combined oxidative phosphorylation deficiency 8 and a related control. Stem Cell Res. 2021, 53, 102374. [CrossRef] [PubMed] 
194. Cerrada, V.; Garcia-Lopez, M.; Moreno-Izquierdo, A.; Villaverde, C.; Zurita, O.; Martin-Merida, M.I.; Arenas, J.; Ayuso, C.; Gallardo, M.E. Derivation of a human DOA iPSC line, IISHDOi006-A, with a mutation in the ACO2 gene: C.1999G>A; p.Glu667Lys. Stem Cell Res. 2019, 40, 101566. [CrossRef] [PubMed]

195. Li, J.; Wu, K.; Guan, J.; Wang, Q.; Wang, H. Generation of a human induced pluripotent stem cell line (CPGHi003-A) from an auditory neuropathy patient with AIFM1 p.R422Q mutation. Stem Cell Res. 2021, 53, 102376. [CrossRef] [PubMed]

196. Cooper, H.M.; Yang, Y.; Ylikallio, E.; Khairullin, R.; Woldegebriel, R.; Lin, K.L.; Euro, L.; Palin, E.; Wolf, A.; Trokovic, R.; et al. ATPase-deficient mitochondrial inner membrane protein ATAD3A disturbs mitochondrial dynamics in dominant hereditary spastic paraplegia. Hum. Mol. Genet. 2017, 26, 1432-1443. [CrossRef]

197. Zhang, Y.; Wang, J.; Zhou, Y.; Li, H.; Li, A.; Tan, X.; Wang, G.; Lei, M. Generation of two induced pluripotent stem cell lines (XACHi0010-A, XACHi0011-A) from a Chinese family with combined oxidative phosphorylation deficiency carrying homozygous and heterozygous C1QBP-L275F mutation. Stem Cell Res. 2020, 47, 101912. [CrossRef] [PubMed]

198. Nakamoto, F.K.; Okamoto, S.; Mitsui, J.; Sone, T.; Ishikawa, M.; Yamamoto, Y.; Kanegae, Y.; Nakatake, Y.; Imaizumi, K.; Ishiura, H.; et al. The pathogenesis linked to coenzyme Q10 insufficiency in iPSC-derived neurons from patients with multiple-system atrophy. Sci. Rep. 2018, 8, 14215. [CrossRef] [PubMed]

199. Romero-Moya, D.; Castano, J.; Santos-Ocana, C.; Navas, P.; Menendez, P. Generation, genome edition and characterization of iPSC lines from a patient with coenzyme Q10 deficiency harboring a heterozygous mutation in COQ4 gene. Stem Cell Res. 2017, 24, 144-147. [CrossRef]

200. Romero-Moya, D.; Santos-Ocana, C.; Castano, J.; Garrabou, G.; Rodriguez-Gomez, J.A.; Ruiz-Bonilla, V.; Bueno, C.; GonzalezRodriguez, P.; Giorgetti, A.; Perdiguero, E.; et al. Genetic rescue of mitochondrial and skeletal muscle impairment in an induced pluripotent stem cells model of coenzyme Q10 deficiency. Stem Cells 2017, 35, 1687-1703. [CrossRef]

201. Rohani, L.; Machiraju, P.; Sabouny, R.; Meng, G.; Liu, S.; Zhao, T.; Iqbal, F.; Wang, X.; Ravandi, A.; Wu, J.C.; et al. Reversible mitochondrial fragmentation in iPSC-derived cardiomyocytes from children with DCMA, a mitochondrial cardiomyopathy. Can. J. Cardiol. 2020, 36, 554-563. [CrossRef]

202. Janz, A.; Chen, R.; Regensburger, M.; Ueda, Y.; Rost, S.; Klopocki, E.; Gunther, K.; Edenhofer, F.; Duff, H.J.; Ergun, S.; et al. Generation of two patient-derived iPSC lines from siblings (LIBUCi001-A and LIBUCi002-A) and a genetically modified iPSC line (JMUi001-A-1) to mimic dilated cardiomyopathy with ataxia (DCMA) caused by a homozygous DNAJC19 mutation. Stem Cell Res. 2020, 46, 101856. [CrossRef] [PubMed]

203. Sequiera, G.L.; Rockman-Greenberg, C.; Dhingra, S. Generation of human induced pluripotent stem cell (hiPSC) line UOMi001-A from a patient with Leigh-like syndrome harbouring compound heterozygous variants in ECHS1 gene. Stem Cell Res. 2020, 48 , 101934. [CrossRef] [PubMed]

204. Yuan, F.; Wang, C.; Xi, J.; Wang, S.; Lin, L.; Wang, Y.; Wang, A.; Wang, C.; Luo, X.; Xu, Q.; et al. Generation of an induced pluripotent stem cell line SHCDNi001-A from a one-year-old Chinese girl with mitochondrial DNA depletion syndrome 13. Stem Cell Res. 2020, 45, 101832. [CrossRef]

205. Marti, S.; Leon, M.; Orellana, C.; Prieto, J.; Ponsoda, X.; Lopez-Garcia, C.; Vilchez, J.J.; Sevilla, T.; Torres, J. Generation of a disease-specific iPS cell line derived from a patient with Charcot-Marie-Tooth type 2K lacking functional GDAP1 gene. Stem Cell Res. 2017, 18, 1-4. [CrossRef]

206. Zurita-Diaz, F.; Galera-Monge, T.; Moreno-Izquierdo, A.; Fraga, M.F.; Ayuso, C.; Fernandez, A.F.; Garesse, R.; Gallardo, M.E. Generation of a human iPSC line from a patient with a mitochondrial encephalopathy due to mutations in the GFM1 gene. Stem Cell Res. 2016, 16, 124-127. [CrossRef]

207. Saporta, M.A.; Dang, V.; Volfson, D.; Zou, B.; Xie, X.S.; Adebola, A.; Liem, R.K.; Shy, M.; Dimos, J.T. Axonal Charcot-MarieTooth disease patient-derived motor neurons demonstrate disease-specific phenotypes including abnormal electrophysiological properties. Exp. Neurol. 2015, 263, 190-199. [CrossRef] [PubMed]

208. Xu, J.; Fu, Y.; Xia, W.; He, J.; Zou, Y.; Ruan, W.; Lou, Q.; Li, Y.; Pan, J.; Li, H.; et al. Generation of induced pluripotent stem cell line, ZJUCHi002-A, from Charcot-Marie-Tooth disease type 2A (CMT2A) patient with a mutation of c.752C $>$ T in MFN2. Stem Cell Res. 2019, 36, 101411. [CrossRef] [PubMed]

209. Ababneh, N.A.; Ali, D.; Barham, R.; Al-Kurdi, B.; Sharar, N.; Al Hadidi, S.; Qanno, O.; Ryalat, A.T.; Salah, B.; Awidi, A. Establishment of a human induced pluripotent stem cell line, JUCTCi012-A, from multiple symmetric lipomatosis (MSL) patient carrying a homozygous Arg707Trp (c.2119C > T) mutation in the MFN2 gene. Stem Cell Res. 2020, 48, 101967. [CrossRef]

210. Sequiera, G.L.; Rockman-Greenberg, C.; Dhingra, S. Induced pluripotent stem cell line UOMi002-A from a patient with Leigh syndrome with compound heterozygous mutations in the NDUFV1 gene. Stem Cell Res. 2020, 48, 101964. [CrossRef]

211. Chen, J.; Riazifar, H.; Guan, M.X.; Huang, T. Modeling autosomal dominant optic atrophy using induced pluripotent stem cells and identifying potential therapeutic targets. Stem Cell Res. Ther. 2016, 7, 2. [CrossRef]

212. Galera-Monge, T.; Zurita-Diaz, F.; Moreno-Izquierdo, A.; Fraga, M.F.; Fernandez, A.F.; Ayuso, C.; Garesse, R.; Gallardo, M.E. Generation of a human iPSC line from a patient with an optic atrophy 'plus' phenotype due to a mutation in the OPA1 gene. Stem Cell Res. 2016, 16, 673-676. [CrossRef]

213. Hauser, S.; Schuster, S.; Theurer, Y.; Synofzik, M.; Schols, L. Generation of optic atrophy 1 patient-derived induced pluripotent stem cells (iPS-OPA1-BEHR) for disease modeling of complex optic atrophy syndromes (Behr syndrome). Stem Cell Res. 2016, 17, 426-429. [CrossRef] [PubMed] 
214. Zurita-Diaz, F.; Galera-Monge, T.; Moreno-Izquierdo, A.; Corton, M.; Ayuso, C.; Garesse, R.; Gallardo, M.E. Establishment of a human DOA 'plus' iPSC line, IISHDOi003-A, with the mutation in the OPA1 gene: C.1635C>A; p.Ser545Arg. Stem Cell Res. 2017, 24, 81-84. [CrossRef] [PubMed]

215. Zhang, X.H.; Xie, Y.; Xu, K.; Li, Y. Generation of an induced pluripotent stem cell line BIOi002-A from a patient with autosomal dominant optic atrophy. Stem Cell Res. 2021, 53, 102278. [CrossRef]

216. Perez-Siles, G.; Cutrupi, A.; Ellis, M.; Screnci, R.; Mao, D.; Uesugi, M.; Yiu, E.M.; Ryan, M.M.; Choi, B.O.; Nicholson, G.; et al. Energy metabolism and mitochondrial defects in X-linked Charcot-Marie-Tooth (CMTX6) iPSC-derived motor neurons with the p.R158H PDK3 mutation. Sci. Rep. 2020, 10, 9262. [CrossRef]

217. Vogtle, F.N.; Brandl, B.; Larson, A.; Pendziwiat, M.; Friederich, M.W.; White, S.M.; Basinger, A.; Kucukkose, C.; Muhle, H.; Jahn, J.A.; et al. Mutations in PMPCB encoding the catalytic subunit of the mitochondrial presequence protease cause neurodegeneration in early childhood. Am. J. Hum. Genet. 2018, 102, 557-573. [CrossRef] [PubMed]

218. Zurita, F.; Galera, T.; Gonzalez-Paramos, C.; Moreno-Izquierdo, A.; Schneiderat, P.; Fraga, M.F.; Fernandez, A.F.; Garesse, R.; Gallardo, M.E. Generation of a human iPSC line from a patient with a defect of intergenomic communication. Stem Cell Res. 2016, 16, 120-123. [CrossRef] [PubMed]

219. Fuchs, N.V.; Schieck, M.; Neuenkirch, M.; Tondera, C.; Schmitz, H.; Wendeburg, L.; Steinemann, D.; Elpers, C.; Rutsch, F.; Konig, R. Generation of three induced pluripotent cell lines (iPSCs) from an Aicardi-Goutieres syndrome (AGS) patient harboring a deletion in the genomic locus of the sterile alpha motif and HD domain containing protein 1 (SAMHD1). Stem Cell Res. 2020, 43, 101697. [CrossRef]

220. Surun, D.; Schneider, A.; Mircetic, J.; Neumann, K.; Lansing, F.; Paszkowski-Rogacz, M.; Hanchen, V.; Lee-Kirsch, M.A.; Buchholz, F. Efficient generation and correction of mutations in human iPS cells utilizing mRNAs of CRISPR base editors and prime editors. Genes 2020, 11, 511. [CrossRef]

221. Dudek, J.; Cheng, I.F.; Balleininger, M.; Vaz, F.M.; Streckfuss-Bomeke, K.; Hubscher, D.; Vukotic, M.; Wanders, R.J.; Rehling, P.; Guan, K. Cardiolipin deficiency affects respiratory chain function and organization in an induced pluripotent stem cell model of Barth syndrome. Stem Cell Res. 2013, 11, 806-819. [CrossRef]

222. Guo, X.; Wang, L.; Chen, K.; Song, S.; Wang, X.; Gu, X.; Niu, C.; Chu, M. Generation of urine-derived iPS cell line via a non-integrative method from a Barth syndrome patient with TAZ gene mutation. Stem Cell Res. 2020, 47, 101886. [CrossRef]

223. Sharma, T.P.; Wiley, L.A.; Whitmore, S.S.; Anfinson, K.R.; Cranston, C.M.; Oppedal, D.J.; Daggett, H.T.; Mullins, R.F.; Tucker, B.A.; Stone, E.M. Patient-specific induced pluripotent stem cells to evaluate the pathophysiology of TRNT1-associated Retinitis pigmentosa. Stem Cell Res. 2017, 21, 58-70. [CrossRef] [PubMed]

224. Galera-Monge, T.; Zurita-Diaz, F.; Gonzalez-Paramos, C.; Moreno-Izquierdo, A.; Fraga, M.F.; Fernandez, A.F.; Garesse, R.; Gallardo, M.E. Generation of a human iPSC line from a patient with Leigh syndrome caused by a mutation in the MT-ATP6 gene. Stem Cell Res. 2016, 16, 766-769. [CrossRef]

225. Peron, C.; Mauceri, R.; Cabassi, T.; Segnali, A.; Maresca, A.; Iannielli, A.; Rizzo, A.; Sciacca, F.L.; Broccoli, V.; Carelli, V.; et al. Generation of a human iPSC line, FINCBi001-A, carrying a homoplasmic m.G3460A mutation in MT-ND1 associated with Leber's Hereditary optic Neuropathy (LHON). Stem Cell Res. 2020, 48, 101939. [CrossRef] [PubMed]

226. Hung, S.S.; Van Bergen, N.J.; Jackson, S.; Liang, H.; Mackey, D.A.; Hernandez, D.; Lim, S.Y.; Hewitt, A.W.; Trounce, I.; Pebay, A.; et al. Study of mitochondrial respiratory defects on reprogramming to human induced pluripotent stem cells. Aging 2016, 8, 945-957. [CrossRef] [PubMed]

227. Lu, H.E.; Yang, Y.P.; Chen, Y.T.; Wu, Y.R.; Wang, C.L.; Tsai, F.T.; Hwang, D.K.; Lin, T.C.; Chen, S.J.; Wang, A.G.; et al. Generation of patient-specific induced pluripotent stem cells from Leber's hereditary optic neuropathy. Stem Cell Res. 2018, 28, 56-60. [CrossRef] [PubMed]

228. Galera, T.; Zurita, F.; Gonzalez-Paramos, C.; Moreno-Izquierdo, A.; Fraga, M.F.; Fernandez, A.F.; Garesse, R.; Gallardo, M.E. Generation of a human iPSC line from a patient with Leigh syndrome. Stem Cell Res. 2016, 16, 63-66. [CrossRef] [PubMed]

229. Hsu, Y.H.; Wu, Y.T.; Huang, C.Y.; Ho, M.C.; Cheng, Y.C.; Syu, S.H.; Lu, H.E.; Chen, Y.C.; Tsai, C.L.; Lin, H.C.; et al. Generation of an induced pluripotent stem cell line from a 39-year-old female patient with severe-to-profound non-syndromic sensorineural hearing loss and a A1555G mutation in the mitochondrial MTRNR1 gene. Stem Cell Res. 2017, 25, 245-249. [CrossRef]

230. Li, S.; Pan, H.; Tan, C.; Sun, Y.; Song, Y.; Zhang, X.; Yang, W.; Wang, X.; Li, D.; Dai, Y.; et al. Mitochondrial dysfunctions contribute to hypertrophic cardiomyopathy in patient iPSC-derived cardiomyocytes with MT-RNR2 mutation. Stem Cell Rep. 2018, 10, 808-821. [CrossRef]

231. Chou, S.J.; Tseng, W.L.; Chen, C.T.; Lai, Y.F.; Chien, C.S.; Chang, Y.L.; Lee, H.C.; Wei, Y.H.; Chiou, S.H. Impaired ROS scavenging system in human induced pluripotent stem cells generated from patients with MERRF syndrome. Sci. Rep. 2016, 6, 23661. [CrossRef]

232. Chou, S.J.; Ko, Y.L.; Yang, Y.H.; Yarmishyn, A.A.; Wu, Y.T.; Chen, C.T.; Lee, H.C.; Wei, Y.H.; Chiou, S.H. Generation of two isogenic human induced pluripotent stem cell lines from a 15year-old female patient with MERRF syndrome and A8344G mutation of mitochondrial DNA. Stem Cell Res. 2018, 30, 201-205. [CrossRef] [PubMed]

233. Fujikura, J.; Nakao, K.; Sone, M.; Noguchi, M.; Mori, E.; Naito, M.; Taura, D.; Harada-Shiba, M.; Kishimoto, I.; Watanabe, A.; et al. Induced pluripotent stem cells generated from diabetic patients with mitochondrial DNA A3243G mutation. Diabetologia 2012, 55, 1689-1698. [CrossRef] [PubMed] 
234. Kodaira, M.; Hatakeyama, H.; Yuasa, S.; Seki, T.; Egashira, T.; Tohyama, S.; Kuroda, Y.; Tanaka, A.; Okata, S.; Hashimoto, H.; et al. Impaired respiratory function in MELAS-induced pluripotent stem cells with high heteroplasmy levels. FEBS Open Bio 2015, 5, 219-225. [CrossRef]

235. Chichagova, V.; Hallam, D.; Collin, J.; Buskin, A.; Saretzki, G.; Armstrong, L.; Yu-Wai-Man, P.; Lako, M.; Steel, D.H. Human iPSC disease modelling reveals functional and structural defects in retinal pigment epithelial cells harbouring the m.3243A $>$ G mitochondrial DNA mutation. Sci. Rep. 2017, 7, 12320. [CrossRef]

236. Peron, C.; Mauceri, R.; Iannielli, A.; Cavaliere, A.; Legati, A.; Rizzo, A.; Sciacca, F.L.; Broccoli, V.; Tiranti, V. Generation of two human iPSC lines, FINCBi002-A and FINCBi003-A, carrying heteroplasmic macrodeletion of mitochondrial DNA causing Pearson's syndrome. Stem Cell Res. 2021, 50, 102151. [CrossRef]

237. Chowdhury, A.; Aich, A.; Jain, G.; Wozny, K.; Luchtenborg, C.; Hartmann, M.; Bernhard, O.; Balleiniger, M.; Alfar, E.A.; Zieseniss, A.; et al. Defective mitochondrial cardiolipin remodeling dampens HIF-1alpha expression in hypoxia. Cell Rep. 2018, 25, 561-570. [CrossRef] [PubMed] 